\title{
Particle size and metal composition of gouging and lancing fumes
}

\author{
M Keyter \\ (BSc; BSc Hons) \\ 22817409
}

Mini-dissertation submitted in partial fulfilment of the requirements for the degree Magister Scientiae in Occupational Hygiene at the Potchefstroom Campus of the North-West University

Supervisor: $\quad$ Ms A van der Merwe

Co-supervisor: Prof A Franken

November 2016 


\section{PREFACE}

Article format was decided upon for this mini-dissertation. For the purpose of uniformity, this dissertation is written according to the guidelines of the journal, Annals of Occupational Hygiene, as available in 2016. The authors take note that the name of this journal will change to Annals of Work Exposures and Health in 2017. Annals of Occupational Hygiene requires that references in the text should be as follows: Jones (1995), or Jones and Brown (1995) or Jones et al. (1995) for more than two authors. References are listed in alphabetical order by name of first author, using Vancouver Style of abbreviation and punctuation. Annals of Occupational Hygiene limits the word count of an article to 5000 words, excluding tables and the abstract. Annals of Occupational Hygiene references books with one author without page numbers. For the purpose of uniformity and ease of reference, books will also be referenced with page numbers in this document.

Chapter 1 consists of an introduction to gouging and lancing processes. Also provided within this chapter is the possible health risks associated with the inhalation of metallic airborne particulate matter liberated during these processes as well as the influence of its chemical and physical characteristics. This section includes the problem statement, the research objectives and the research questions. Chapter 2 contains a thorough discussion of the metal fumes and particulate matter emitted during gouging and lancing processes, the physical and chemical characteristics of the airborne particulate matter, the health effects associated with airborne particulate matter and metal fumes as well as nanoparticles. Chapter 3 is written in the article format. Tables and Figures are included in this section to present the findings of this study in a comprehensive format. Chapter 4 is also written in the article format. Figures are included in this section to present the findings of this study. Chapter 5 is the concluding chapter with a further discussion, recommendations and limitations of the study. Chapter 6 comprise the Annexures which includes additional tables, the Language Editing Certificate and a Certificate of Recognition for winning the

Student Poster Presentation Award at the Occupational Hygiene (SAIOH) Conference in October 2016. 
In order to prevent confusion, the following definitions as used in this mini-dissertation are explained:

Inhalable size fraction: All particles with an aerodynamic diameter of less than $100 \mu \mathrm{m}$ (Wilson et al., 2002).

Thoracic size fraction: Particles with an aerodynamic diameter of less than $10 \mu \mathrm{m}$ (Reist, 2000).

Respirable size fraction: Particles with an aerodynamic diameter of less than $4 \mu \mathrm{m}$ (Petavratzi et al., 2005).

Nanoparticles: Particles with an aerodynamic diameter in the nanometre range (Oberdörster et al., 2013).

Gouging: A metal cutting method used for the preparation of a weld groove or for the removal of a defective welding zone (Sasse et al., 1978; Lyndon and Platcow, 2011).

Lancing: A metal cutting method used to sever or remove metal by using oxygen (Sasse et al., 1978; Lyndon and Platcow, 2011).

Particulate matter. Particulate matter is a heterogeneous, complex mixture of small particles, as well as liquid droplets, and consists of various different physical characteristics and chemical components (Kelly and Fussel, 2012; United States Environmental Protection Agency (US EPA), 2015).

Metal fumes: Metal fumes are usually generated during welding or thermal cutting operations and are formed when vaporised materials condense in cool air, giving rise to very fine solid particles (Plog, 2002; Pickford and Davies, 2007). 


\section{References}

Kelly FJ, Fussel JC. (2012) Size, source and chemical composition as determinants of toxicity attributable to ambient particulate matter. Atmos Environ; 60: 504-526.

Lyndon GS, Platcow PA. (2011) Welding and Thermal Cutting. Available from: URL: http://www.ilo.org/iloenc/part-xiii/metal-processing-and-metal-working-industry/metalprocessing-and-metal-working/item/676-welding-and-thermal-cutting (accessed 6 July 2015)

Oberdörster G, Kane AB, Klaper RD, Hurt RH. (2013) Nanotoxicology. In Klaassen CD, editor. Casarett \& Doull's Toxicology: The Basic Science of Poison. China: McGraw-Hill. p. 1189-1229. ISBN 978-0-07-176923-5.

Petavratzi E, Kingman S, Lowndes I. (2005) Particulates from Mining Operations: A Review of Sources, Effects and Regulations. Miner Environ; 18: 1183-1199.

Pickford G, Davies B. (2007) Aerosols. In Tillman C, editor. Principles of Occupational Health \& Hygiene: An Introduction. Singapore: ANL Printers. p. 125-171. ISBN 9781741750584.

Plog BA. (2002) Overview of Industrial Hygiene. In Plog BA, Quinlan PJ, editors. Fundamentals of Industrial Hygiene. United States of America: National Safety Council. p. 3-32. ISBN 0-87912216-1.

Reist PC. (2000) Basic Aerosol Science. In Harris RL, editor. Patty's Industrial Hygiene. United States of America: John Wiley \& Sons, Inc. p. 355-410. ISBN 0-471-29756-9.

Sasse FH, Frohlich RL, Green RD et al. (1978) Arc and Oxygen Cutting. In Kearns WH, editor. Welding Handbook Volume 2: Welding Processes - Arc and Gas Welding and Cutting, Brazing, and Soldering. Miami, FL: American Welding Society. p. 459-516. ISBN 0-87171-148-6.

United States Environmental Protection Agency (US EPA). (2015) Particulate Matter (PM). Available from: URL: http://www3.epa.gov/pm/ (accessed 28 January 2016)

Wilson WE, Chow JC, Claiborn C et al. (2002) Monitoring of particulate matter outdoors. Chemosphere; 49: 1009-1043. 


\section{AUTHOR'S CONTRIBUTION}

The study was planned and executed by a team of researchers. The contribution of each researcher is listed below:

\begin{tabular}{|l|l|}
\hline Name & Contribution \\
\hline Ms M Keyter & $\begin{array}{l}\text { 1. Designing and planning of the study. } \\
\text { 2. Literature research, interpretation of data and writing of the } \\
\text { articles. }\end{array}$ \\
\hline 3. Execution of monitoring processes. \\
4. Writing of mini-dissertation.
\end{tabular}

The following is a statement from the supervisors that confirms each individual's role in the study:

I declare that I have approved the articles and that my role in the study as indicated above is representative of my actual contribution and that I hereby give my consent that it may be published as part of Marelé Keyter's M.Sc (Occupational Hygiene) mini-dissertation. 


\section{DEDICATION}

I would like to dedicate this project to my mother, Ansu Rossouw, my best friend, confidant and support system, who helped and carried me through my studies and this project. I love you more than you know, moeder! 


\section{ACKNOWLEDGEMENTS}

Firstly, I would like to praise and thank my heavenly Father for blessing me with the opportunity to study and who has gifted me with patience, perseverance and the talents to complete this project.

I would like to thank my supervisor, Ms Alicia van der Merwe, and co-supervisor, Prof Anja Franken, for their continuous assistance, guidance, support, time, effort, and encouraging words. Your doors were always open when I needed help and you always answered my 'stupid' questions.

I would like to thank Prof Cas Badenhorst for the opportunity to complete this project. I would also like to thank Ms Zoe Selenati-Dreyer for her assistance and advice in planning the sampling procedure and organising everything from the mine's side, and Mr. Manny Shepherd for his guidance and help during the sampling procedure as well as every person at the mine who made the sampling process so much easier.

A big thank you to Ms Marike Cockeran for the help with the statistical processing of the data.

Thank you to Mr Corné van der Merwe for helping me with technical aspects of the sampling procedure, as well as for building the sampling stand used in this project.

I would also like to thank Ms Yolandi Jordaan for accompanying me during my sampling.

Thank you to my friends, as well as the OHHRI niche area members for all the support and advice during this project.

Last but not least, I would like to thank my parents for the opportunity to study as well as the endless love and support and words of encouragement. 


\section{SUMMARY}

Title: Particle size and metal composition of gouging and lancing fumes

Background: Gouging (used for preparation of the weld groove) and lancing (severs or removes metal) processes during mining maintenance operations liberate fumes of unknown particle sizes and metal composition. These fumes are formed when vaporised materials condense in cool air. These processes give rise to very fine solid particles of sizes usually smaller than $1 \mu \mathrm{m}$ in diameter which will generally agglomerate to form bigger clusters of particles. Inhalation of such a "metal fume mixture" may lead to adverse health effects. Gouging and lancing, specifically, liberate fumes of unknown particle sizes and metal composition, as most studies only focus on welding fumes.

Aims and objectives: A field study was conducted to determine the particle size fractions as well as metal composition of fumes emitted during gouging and lancing processes. This study provided the necessary information to employers on what their workers are exposed to and therefore, how to prevent or control exposure to these fumes and this may improve occupational health and hygiene of workers utilising these gouging and lancing methods. The study also aimed to include metal fumes and particle fractions not previously included (such as nanoparticles) during respiratory exposure sampling. The determination of the particle size fractions and metal composition of the metal fume mixtures made it possible to determine the possible health effects associated with the inhalation thereof.

Methods: Randomised side-by-side area samples were collected of metal cutting fumes liberated during gouging and lancing processes, respectively. These processes form part of maintenance work and was performed in three workshops at an open cast iron ore mine in South Africa. Samplers included the Institute of Occupational Medicine (IOM) sampler (inhalable fraction), a GK2.69 cyclone (thoracic fraction), an aluminium cyclone (respirable fraction), a Nanoparticle Respiratory Deposition (NRD) sampler (nano-size fraction) and an open-face filter cassette (particle size distribution). These samplers were mounted at a minimum height of $1.3 \mathrm{~m}$ and a maximum height of $1.7 \mathrm{~m}$ which is representative of the height of workers standing up by means of a randomised sampling station. Samples were collected $2 \mathrm{~m}$ from the source during gouging processes and at a range of between 5 and $10 \mathrm{~m}$ from the source during lancing processes. $A$ total of 46 samples were collected during gouging processes (23 in the maintenance workshop and 23 in the mining contractor's workshop) and 26 during lancing processes.

Results: Particles in all fractions were present in the metal fumes emitted during gouging and lancing processes. Ambient workplace concentrations of the nano-sized fraction indicated a range of $1.01-3.40 \mathrm{mg} / \mathrm{m}^{3}$ in the workshops. A total of 26 metals were present in the various particle 
fraction sizes and included arsenic, chromium, cobalt, lead, manganese, mercury and nickel. Lead was mostly found during lancing whereas manganese and nickel were found in all of the workshops and fractions sampled. Lancing processes $(\bar{x}=32.3 \mathrm{~nm})$ emit on average smaller particles than gouging processes $(\bar{x}=171.8 \mathrm{~nm})$. The various fraction sizes did not statistically differ between gouging and lancing. Statistically significant differences were found between gouging and lancing for copper, iron, molybdenum and nickel emission, with copper, iron and nickel emission showing a higher concentration during gouging processes and molybdenum emission showing a higher concentration during lancing processes. In the nano-size fraction, the head nut liberated the highest mean ambient concentration level $\left(2.46 \mathrm{mg} / \mathrm{m}^{3}\right)$ and backhoe shovel 2 the lowest $\left(1.74 \mathrm{mg} / \mathrm{m}^{3}\right)$. Fumes emitted from backhoe shovel 1 , the crusher liner and the axle liner contained the smallest particles with averages of $40.3 \mathrm{~nm}, 28.5 \mathrm{~nm}$ and $36.1 \mathrm{~nm}$, respectively.

Conclusions: Particle size fractions within the inhalable, thoracic, respirable as well as nanosize fractions were present in the metal fumes. Lancing could be considered more hazardous than gouging as mean particle sizes are smaller than particles emitted during gouging. Nanotoxicology is still an unfamiliar field and nanoparticles may cause detrimental health effects beyond the respiratory system. This indicates the necessity to include the nano-size fraction during future personal exposure assessments and monitoring in addition to inhalable and respirable sampling and may guide the mine to implement various control and safety measures, specifically for nanoparticles, to protect their workers' health.

Keywords: nanoparticles; particle size fractions; mining maintenance work; base metal. 


\section{OPSOMMING}

Titel: Partikelgrootte en metaalsamestelling van gutssnywerk- en termiese suurstofsnywerkdampe

Agtergrond: Gutssnywerk- (gebruik vir die voorbereiding van die sweisgroef) en termiese suurstofsnywerk- (gebruik vir die verwydering van metaal) prosesse stel dampe van onbekende partikelgroottes en metaalsamestelling vry. Hierdie metaaldampe vorm wanneer verdampte stowwe in aanraking kom met koeler lug. Die prosesse veroorsaak dat baie fyn, soliede partikels vrygestel word. Hierdie partikels het gewoonlik ' $n$ deursnee van kleiner as $1 \mu \mathrm{m}$ en sal oor die algemeen agglomereer om groter groepe van partikels te vorm. Die inaseming van hierdie "metaaldamp-mengsel" kan aanleiding gee tot nadelige gesondheidseffekte. Die partikelgroottes en metale wat spesifiek deur gutssnywerk- en termiese suurstofsnywerk-prosesse vrygestel word, is onbekend omdat meeste studies slegs fokus op metaaldampe.

Doelstellings en doelwitte: ' $n$ Veldstudie is uitgevoer om die partikelgrootte fraksies asook die metaalsamestelling van dampe, wat vrygestel is tydens gutssnywerk en termiese suurstof snywerk, te bepaal. Hierdie studie verskaf die nodige inligting aan werkgewers oor waaraan hulle werkers blootgestel word en dus hoe om hierdie blootstelling te voorkom en te beheer en dit sal die beroepsgesondheid en -higiëne van werkers, wat gebruik maak van gutssnywerk en termiese suurstofsnywerk te verbeter. Die doel van hierdie studie was ook om metaaldampe en partikel fraksies, wat voorheen nie ingesluit was in respiratoriese monsterneming nie, in te sluit. Deur die partikelgrootte fraksies en metaalsamestelling van die metaaldamp mengsels te bepaal, lei daartoe dat die moontlike gesondheidseffekte, wat deur die inaseming daarvan veroorsaak word, geëvalueer kan word.

Metodes: Ewekansige sy-aan-sy area monsters van metaaldampe, vrygestel tydens snyprosesse, is versamel. Hierdie prosesse maak deel uit van instandhoudingswerk en is uitgevoer in drie werkswinkels by ' $n$ oopgroef ystererts myn in Suid-Afrika. Die volgende monsternemers is gebruik: "Institute of Occupational Medicine" (IOM) monsternemers (inasembare fraksie), GK2.69-siklone (torakale fraksie), aluminium siklone (respireerbare fraksie), "Nanoparticle Respiratory Deposition" (NRD)-monsternemers (nano-grootte-fraksie) en 'n oop-gesig-filterkasset (partikelgrootte-verspreiding). Hierdie monsternemers is gemonteer op ' $n$ minimum hoogte van 1,3 m en 'n maksimum hoogte van $1,7 \mathrm{~m}$, verteenwoordigend van die menslike respiratoriese stelsel, met behulp van ' $n$ monsternemer stasie. Monsters is ingesamel binne $2 \mathrm{~m}$ vanaf die bron tydens gutssnywerk-prosesse en tussen 5 en $10 \mathrm{~m}$ vanaf die bron tydens termiese suurstofsnywerk-prosesse. 'n Totaal van 46 monsters is tydens gutssnywerk- 
prosesse (23 in die onderskeie werkswinkels) en 26 monsters is ingesamel tydens termiese suurstofsnywerk-prosesse.

Resultate: Partikels in al die fraksiegroottes was teenwoordig in die metaaldampe wat vrygestel is tydens gutssnywerk- en termiese suurstofsnywerk-prosesse. Omgewingskonsentrasies van die nano-grootte-fraksie het ' $\mathrm{n}$ reikwydte van $1,01-3,40 \mathrm{mg} / \mathrm{m}^{3}$ in die werkswinkels aangedui. ' $\mathrm{n}$ Totaal van 26 metale was teenwoordig in die verskillende fraksiegroottes en het die volgende ingesluit: arseen, chroom, kobalt, lood, mangaan, kwik en nikkel. Lood is meestal aangetref in termiese suurstofsnywerkdampe en mangaan en nikkel is aangetref in die dampe in al die werkswinkels en fraksiegroottes wat gemeet is. Termiese suurstofsnywerk stel gemiddeld kleiner nanopartikels vry as die gutssnywerk-prosesse. Die verskillende fraksiegroottes het nie statisties betekenisvol verskil tussen gutssnywerk- en termiese suurtofsnywerk-prosesse nie. Statistiese beduidende verskille is gevind tussen die prosesse vir koper, yster, molibdeen en nikkel vrystelling, waar koper, yster en nikkel vrystelling hoër konsentrasies getoon het tydens gutssnywerk-prosesse en molibdeen vrystelling hoër konsentrasies getoon het tydens termiese suurstofsnywerk-prosesse. In die nano-grootte-fraksie, het die moer die hoogste gemiddelde omgewingskonsentrasievlak $\left(2,46 \mathrm{mg} / \mathrm{m}^{3}\right)$ vrygestel en skepgraaf 2 die laagste $\left(1,74 \mathrm{mg} / \mathrm{m}^{3}\right)$. Dampe vrygestel deur die skepgraaf 1 , die ertsbreker-voering en as-voering het die kleinste partikels bevat, met onderskeidelik gemiddelde groottes van 40,3 nm, 28,5 nm en $36,1 \mathrm{~nm}$.

Gevolgtrekking: Partikels in die inasembare, torakale, respireerbare en nano-grootte-fraksies was teenwoordig in die metaaldampe. Termiese suurstofsnywerk kan gevaarliker as gutssnywerk beskou word, omdat die gemiddelde partikelgroottes wat vrygestel word, kleiner is as partikels wat vrygestel word tydens gutssnywerk-prosesse. Nanotoksikologie is steeds ' $n$ onbekende veld en nanopartikels kan nadelige gesondheidsgevolge hê buite die respiratorise stelsel. Hierdie inligting dui die noodsaaklikheid aan om die nano-grootte-fraksie in te sluit tydens toekomstige persoonlike blootstelling-asseserings en -monitering en kan die myn leiding gee om verskeie beheer- en veiligheidsmaatreëls, spesifiek vir nanopartikels te implementeer.

Sleutelwoorde: nanopartikels; partikelgrootte fraksies; mynbou instandhoudingswerk; basismetaal. 


\section{TABLE OF CONTENTS}

PREFACE

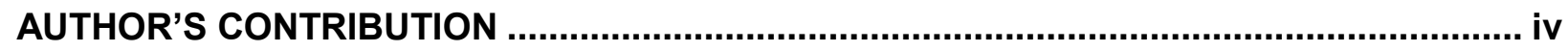

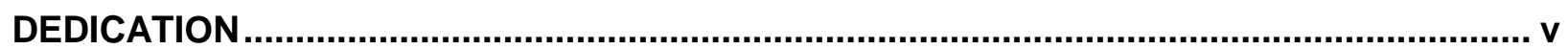

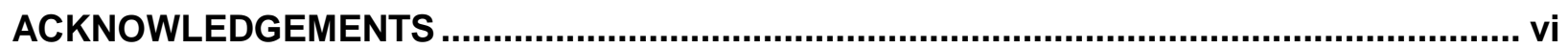

SUMMARY

OPSOMMING

LIST OF TABLES

LIST OF FIGURES

LIST OF SYMBOLS AND ABBREVIATIONS .................................................................... xvii

STANDARD UNITS

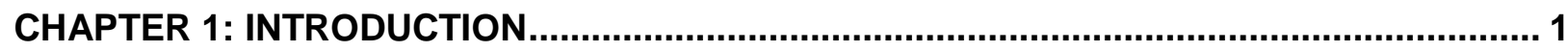

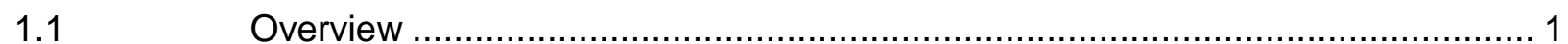

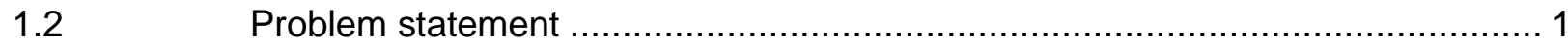

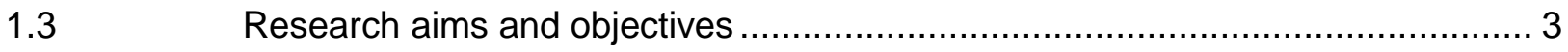

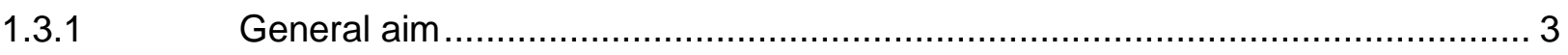

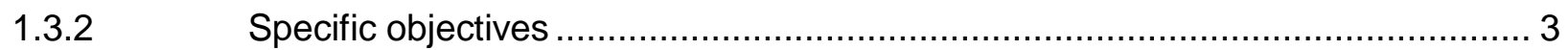

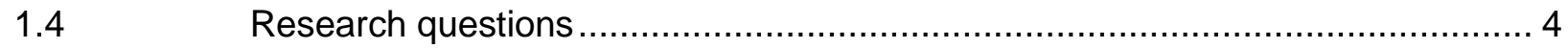

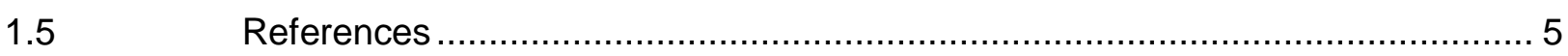

CHAPTER 2: LITERATURE REVIEW

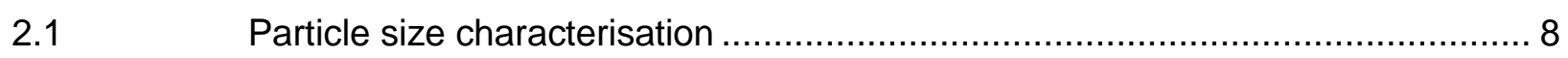


2.3 Physical and chemical characteristics of particulate matter.

2.4.1 Health effects associated with particulate matter ..... 10 
2.9.10 Nickel

2.9.11 Silver

2.9 .12

Tin 28

2.9 .13

Zinc 28

2.10 References 30

CHAPTER 3: ARTICLE 45

Particle size and metal composition of gouging and lancing fumes

3.1 Abstract 48

3.2

Introduction. 49

3.3

Methodology. 51

3.4

Results 54

3.5

Discussion 65

3.6

Conclusions 68

3.7

References 70

CHAPTER 4: CASE STUDY 75

Fumes released during gouging and lancing on various metal workpieces: A case study

4.1

Abstract 76

4.2

Introduction. 77

4.3

Methodology 78

4.4 Results . 80 
5.4.1 Engineering and administrative control measures..................................... 95

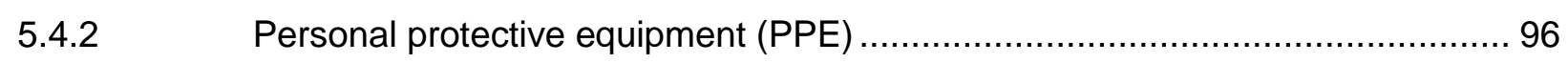

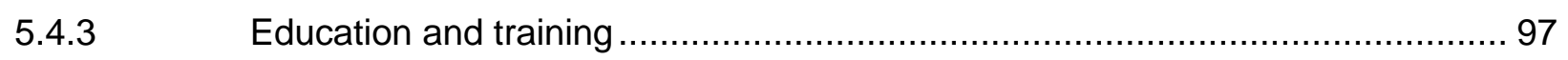




\section{LIST OF TABLES}

\section{CHAPTER 2}

Table 1: IARC classification system

Table 2: Table depicting other metals with their most important health effects .29

\section{CHAPTER 3}

Table 1: Different samplers used during sampling procedure .51

Table 2: Total samples at various sampling areas .52

Table 3: Descriptive statistical data for the inhalable, thoracic and respirable particle size fractions .56

Table 4: Descriptive statistical data (concentrations, in $\mathrm{mg} / \mathrm{m}^{3}$ ) for the nano-sized particle fraction collected during the diffusion stage of the NRD sampler...... .57

Table 5: Descriptive statistical data for the nanometre particle size distribution (in nanometre) .58

Table 6: Descriptive statistical data for various metals present in the respirable particle size fraction ....... .60

Table 7: Descriptive statistical data for various metals present in the nanometre particle size fraction .....61

Table 8: Effect sizes determined for fraction sizes in three workshops 65

\section{CHAPTER 4}

Table 1: Samplers used. .79

\section{CHAPTER 6}

Table 1: Descriptive statistical data for various metals present in the inhalable particle size fraction .......102

Table 2: Descriptive statistical data for various metals present in the thoracic particle size fraction 103 


\section{LIST OF FIGURES}

\section{CHAPTER 2}

Figure 1: ISO/CEN/ACGIH sampling conventions for health related particle fractions

Figure 2: Model predictions of deposition fractions for different particle sizes in humans 17

\section{CHAPTER 3}

Figure 1: Particle size distribution of fumes emitted at the (a) maintenance workshop during gouging, (b) mining contractor's workshop during gouging and (c) secondary crusher workshop during lancing...............

Figure 2: SEM (scanning electron microscopy) photos of particulate matter present in fumes. 64

\section{CHAPTER 4}

Figure 1: Ambient workplace concentration levels of the (a) inhalable fraction, (b) thoracic fraction, (c) respirable fraction and (d) nano-size fraction emitted during work on various metal workpieces. 81

Figure 2: Figure showing metals present in fumes emitted during work on various metal workpieces .......82

Figure 3: Particle size distribution of fumes emitted from various metal workpieces .83 


\section{LIST OF SYMBOLS AND ABBREVIATIONS}

$\mathrm{AC}$

Alternating Current

ACGIH American Conference of Governmental Industrial Hygienists

$\mathrm{Ag}$

Silver

Al Aluminium

As Arsenic

$\mathrm{Ba} \quad$ Barium

C Carbon

Ca Calcium

Cd Cadmium

CEN Comité Européen de Normalisation

CFC Closed-face Filter Cassette

CIS Conical Inhalable Sampler

Co Cobalt

$\mathrm{Cr} \quad$ Chromium

$\mathrm{Cu} \quad$ Copper

DC Direct Current

$\mathrm{Fe} \quad$ Iron

GI Gastrointestinal

GSP Gesamtstaubprobenahmesystem (Total Dust Sampling System)

$\mathrm{Hg} \quad$ Mercury

IARC International Agency for Research on Cancer

ICP-AES Inductively Coupled Plasma - Atomic Emission Spectroscopy

IOM Institute of Occupational Medicine

ISO International Standards Organisation

K Potassium

MDHS Methods for the Determination of Hazardous Substances

MFF Metal Fume Fever

$\mathrm{Mg} \quad$ Magnesium

Mn Manganese

Mo Molybdenum

$\mathrm{Na} \quad$ Sodium

$\mathrm{Ni} \quad$ Nickel

$\mathrm{NIOSH} \quad$ National Institute for Occupational Safety and Health

NPs Nanoparticles

NRD Nanoparticle Respiratory Deposition 


$\begin{array}{ll}\text { OEL } & \text { Occupational Exposure Limit } \\ \text { OFC } & \text { Open-face Filter Cassette } \\ \text { OSHA } & \text { Occupational Safety and Health Administration } \\ \mathrm{P} & \text { Phosphorus } \\ \mathrm{Pb} & \text { Lead } \\ \mathrm{PCIS} & \text { Personal Cascade Impactor Sampler } \\ \mathrm{Pd} & \text { Palladium } \\ \mathrm{PPE} & \text { Personal Protective Equipment } \\ \mathrm{PPI} & \text { Parallel Particle Impactor } \\ \mathrm{RPE} & \text { Respiratory Protective Equipment } \\ \mathrm{S} & \text { Sulphur } \\ \mathrm{Sb} & \text { Antimony } \\ \mathrm{Se} & \text { Selenium } \\ \mathrm{SiO} & \\ \mathrm{SKC} & \text { Silicon dioxide } \\ \mathrm{Sn} & \text { Manufacturer of air sampling equipment } \\ \mathrm{Sr} & \text { Tin } \\ \mathrm{Ti} & \text { Strontium } \\ \mathrm{TWA} & \text { Titanium } \\ \mathrm{US} & \text { Time-weighted average } \\ \mathrm{V} & \text { United States } \\ \mathrm{W} & \text { Vanadium } \\ \mathrm{Zn} & \text { Tungsten } \\ \mathrm{Zr} & \text { Zinc } \\ & \text { Zirconium } \\ & \end{array}$




\section{STANDARD UNITS}

$\begin{array}{ll}\% & \text { Percentage } \\ < & \text { Less than } \\ > & \text { Greater than } \\ \leq & \text { Less or equal than } \\ \geq & \text { Greater or equal than } \\ \mu \mathrm{g} & \text { Micrograms } \\ \mu \mathrm{m} & \text { Micrometre } \\ \mathrm{I} / \mathrm{min} & \text { Litres per minute } \\ \mathrm{m} & \text { Metre } \\ \mathrm{m} & \text { Cubic metre } \\ \mathrm{mg} & \text { Milligrams } \\ \mathrm{mg} / \mathrm{m}^{3} & \text { Milligram per cubic metre } \\ \mathrm{min} & \text { Minute } \\ \mathrm{mm} & \text { Millimetre } \\ \mathrm{nm} & \text { Nanometre }\end{array}$




\section{CHAPTER 1: INTRODUCTION}

\subsection{Overview}

Welding is an industrial process performed globally on a frequent basis. Nearly $2 \%$ of the population working in industrialised countries use welding processes and associated activities such as metal cutting as part of their employment activities (Mohan et al., 2014).

While there are various hazards associated with welding processes, exposure to fumes emitted during such activities is considered to be the most hazardous (Mohan et al., 2014). This fume contains a mixture of toxic metals and is hazardous to humans. The fume can cause adverse health effects, such as asthma, pneumoconiosis, metal fume fever, a decrease in lung function and obstructive pulmonary disease, to name a few (Sriram et al., 2015).

\subsection{Problem statement}

According to the United States Department of Labour, Bureau of Labour Statistics, there are more than two million full-time employees that use welding and associated activities worldwide (Bureau of Labor Statistics, U.S. Department of Labor, 2014). These employees are a heterogeneous population and the health effects that are caused by the inhalation of the fumes emitted by metal cutting are difficult to assess. This is further complicated by varying tasks, different types of materials used, different types of welding processes as well as interindividual variation in susceptibility with regard to the respiratory tract (Cena et al., 2014; Hariri et al., 2014).

Metal fumes are usually generated during welding or thermal cutting operations and a fume is formed when vaporised materials, generally metals, condense in cool air (Plog, 2002; Pickford and Davies, 2007). These processes give rise to very fine solid particles of sizes usually smaller than $1 \mu \mathrm{m}$ in diameter and they normally agglomerate to form bigger clusters of particles (Zeidler-Erdely et al., 2012; Hariri et al., 2014). The bigger clusters are larger in diameter and have different physical properties compared to a single particle and may react differently in the human respiratory system (Reist, 2000).

Metal or thermal cutting is a process that is closely associated with welding processes and can be performed using gouging or lancing (Lyndon and Platcow, 2011). Gouging is used for the preparation of the weld groove or for the removal of defective welding zones. Lancing is a cutting method that severs or removes metal (Sasse et al., 1978; Lyndon and Platcow, 2011). These processes will be discussed in detail in Chapter 2. Gouging and lancing produce fumes similar to welding processes and these fumes contain particles of different aerodynamic 
diameters and properties which can be inhaled into the respiratory tract and potentially cause chronic health effects (Hartmann et al., 2014; Sriram et al., 2015).

Particle size fractions that are biologically relevant can be divided into three groups, namely inhalable, thoracic and respirable particle size fractions. These fractions are based on the difference in particle aerodynamic diameter (Cherrie and Aitken, 1999; Notø et al., 2016). The inhalable fraction is the fraction of particles which can be deposited on all surfaces in the respiratory tract. However, due to their particle size range this fraction will deposit mainly in the nose and mouth. The thoracic fraction is the fraction of particles that is mostly deposited in the lung airways and gas exchange region, whereas the respirable fraction mostly deposits in the gas exchange region of the lung (the alveoli) due to their small size (Cherrie and Aitken, 1999; Pickford and Davies, 2007).

The respirable fraction also includes nanoparticles that are in the submicron range and these particles are measured in nanometres (nm) (Oberdörster et al., 2013; Andujar et al., 2014). Most publications refer to nanoparticles as particles that are $100 \mathrm{~nm}$ or smaller in diameter (Stephenson et al., 2003; Donaldson et al., 2005; Oberdörster et al., 2005; Win-Shwe and Fujimaki, 2011; Chang et al., 2013; Oberdörster et al., 2013; Andujar et al., 2014). Owing to the fact that their size range is smaller, nanoparticles can cause more toxic responses than larger particles due to their ability to be absorbed into the blood circulation from where they elicit toxic effects in other regions of the body (Kang et al., 2011; Lehman-McKeeman, 2013). Characterising particle fractions present in the metal cutting fumes are important for determining the presence of respirable and nanoparticle fractions as it has not been done before for gouging and lancing processes, specifically. It is critical due to the ability of these particles to penetrate to the deepest structures of the lungs, be absorbed into the blood circulation and cause adverse health effects in other regions of the body (Lehman-McKeeman, 2013).

This study aims to provide insight into the characterisation of metal fumes that are emitted from the metal cutting methods, gouging and lancing, with specific interest in the fraction size and metal composition thereof. Determining the particle size and the metal composition of the fumes emitted will be advantageous to assess the possible health effects associated with the inhalation of these particles to employees in these areas. This study aims to include metal fumes and particle size fractions not previously included (such as nanoparticles) during respiratory sampling. The study also aims to improve occupational health and hygiene of workers utilising lancing and gouging methods by determining the particle size fraction and the metal composition of the particles, since these workers do not know what they are working 
on and therefore, what they are exposed to. This study will indicate to the employer the particle size distribution as well as the metals that are present in gouging and lancing fumes. The employer will therefore be able to determine which precautionary, safety and control measures to implement in order to protect their employees as well as what needs to be included in the mine's monitoring regime.

\subsection{Research aims and objectives}

\subsubsection{General aim:}

The general aim of this study is to determine the particle size (physical properties) and metal composition (chemical properties) of the airborne particulate matter present in metal fumes emitted during gouging and lancing processes in workshops at a mine in South Africa in support of an improved understanding of the potential health risk posed.

\subsubsection{Specific objectives:}

The specific objectives of this study are:

- To determine particle size fractions of welding fumes emitted by gouging and lancing methods using IOM samplers (inhalable fraction), GK2.69 cyclone samplers (thoracic fraction), SKC aluminium cyclone samplers (respirable fraction) and NRD samplers (nanometre fraction) at the maintenance workshop, the mining contractor's workshop and the secondary crusher workshop by means of gravimetric analysis.

- To determine the metal composition of welding fumes emitted by gouging and lancing methods at the maintenance workshop, the mining contractor's workshop and the secondary crusher workshop by means of metal element scan analysis using an Inductively Coupled Plasma - Atomic Emission Spectroscopy (ICP-AES).

- To determine the particle size distribution range of welding fumes emitted by gouging and lancing methods using an open-faced $37 \mathrm{~mm}$ filter cassette at the maintenance workshop, the mining contractor's workshop and the secondary crusher workshop by means of dynamic light scattering. 


\subsection{Research questions}

Literature indicates that metal fumes contain inhalable, thoracic and respirable particulate matter. However, limited research has been done on the presence of the nano-sized particulate fraction in welding fumes (Vincent and Brosseau, 1995; Zeidler-Erdely et al., 2012; Hariri et al., 2014; Tashiro et al., 2015). Nanoparticles tend to elicit stronger toxic responses than larger particles due to their ability to be absorbed from the lungs into the blood circulation and travel to target organs (Kang et al., 2011; Oberdörster et al., 2013). Therefore, it raises the first research question:

Question 1: Are nanoparticles present in the metal fumes emitted from gouging and lancing methods?

The chemical composition of particles is a very important consideration as it will influence the toxicological profile of the fume and a combination of different metals may cause an additive effect which can exacerbate adverse health effects (Hartmann et al., 2014; Sriram et al., 2015). Therefore, it raises the second research question:

Question 2: What is the metal composition of the fumes emitted from gouging and lancing to which employees are exposed? 


\subsection{References}

Andujar P, Simon-Deckers A, Galateau-Sallé F et al. (2014) Role of metal oxide nanoparticles in histopathological changes observed in the lung of welders. Part Fibre Toxicol; 11: 1-13.

Bureau of Labor Statistics, U.S. Department of Labor. (2014) Occupational Outlook Handbook: Welding, soldering, and Brazing Workers. Available from: URL: http://www.bls.gov/ooh/production/welders-cutters-solderers-and-brazers.htm (accessed 4 September 2015)

Cena LG, Keane MJ, Chisholm WP et al. (2014) A novel method for assessing respiratory deposition of welding fume nanoparticles. J Occup Environ Hyg; 11: 771-780.

Chang C, Demokritou P, Shafer M, Christiani D. (2013) Physicochemical and toxicological characteristics of welding fume derived particles generated from real time welding processes. Environ Sci: Processes Impacts; 15: 214-224.

Cherrie JW, Aitken RJ. (1999) Measurement of human exposure to biologically relevant fractions of the total aerosol. Occup Environ Med; 56: 747-752.

Donaldson K, Tran L, Jimenez LA et al. (2005) Combustion-derived nanoparticles: A review of their toxicology following inhalation exposure. Part Fibre Toxicol; 2: 1-14.

Hariri A, Azreen N, Abdull N et al. (2014) Determination of customer requirement for welding fumes index development in automotive industries by using quality function deployment approach. Int J Automot Mech Eng; 9: 1609-1619.

Hartmann L, Bauer M, Bertram J et al. (2014) Assessment of the biological effects of welding fumes emitted from metal inert gas welding processes of aluminium and zinc-plated materials in humans. Int J Hyg Environ Health; 217: 160-168.

Kang GS, Gillespie PA, Gunnison A et al. (2011) Long-term inhalation exposure to nickel nanoparticles exacerbated atherosclerosis in a susceptible mouse model. Environ Health Persp; 119: 176-181.

Lehman-McKeeman LD. (2013) Absorption, distribution and excretion of toxicants. In Klaassen CD, editor. Casarett \& Doull's Toxicology: The Basic Science of Poison. China: McGraw-Hill. p. 153-183. ISBN 978-0-07-176923-5. 
Lyndon GS, Platcow PA. (2011) Welding and thermal cutting. Available from: URL: http://www.ilo.org/iloenc/part-xiii/metal-processing-and-metal-working-industry/metalprocessing-and-metal-working/item/676-welding-and-thermal-cutting (accessed 6 July 2015)

Mohan S, Sivapirakasam SP, Bineesh P, Satpathy KK. (2014) Strategies for controlling welding fumes at the source - A review. Appl Mech Mater; 592-594: 2539-2545.

Notø HP, Nordby KC, Eduard W. (2016) Relationships between Personal Measurements of 'Total' Dust, Respirable, Thoracic, and Inhalable Aerosol Fractions in the Cement Production Industry. Ann Occup Hyg; 60: 453-466.

Oberdörster G, Kane AB, Klaper RD, Hurt RH. (2013) Nanotoxicology. In Klaassen CD, editor. Casarett \& Doull's Toxicology: The Basic Science of Poison. China: McGraw-Hill. p. 11891229. ISBN 978-0-07-176923-5.

Oberdörster G, Oberdörster E, Oberdörster J. (2005) Nanotoxicology: An Emerging Discipline Evolving from Studies of Ultrafine Particles. Environ Health Persp; 113: 823-839.

Pickford G, Davies B. (2007) Aerosols. In Tillman C, editor. Principles of occupational health \& hygiene: An introduction. Singapore: ANL Printers. p. 125-171. ISBN 9781741750584.

Plog BA. (2002) Overview of Industrial Hygiene. In Plog BA, Quinlan PJ, editors. Fundamentals of Industrial Hygiene. United States of America: National Safety Council. p. 332. ISBN 0-87912-216-1.

Reist PC. (2000) Basic aerosol science. In Harris RL, editor. Patty's Industrial Hygiene. United States of America: John Wiley \& Sons, Inc. p. 355-410. ISBN 0-471-29756-9.

Sasse FH, Frohlich RL, Green RD et al. (1978) Arc and oxygen cutting. In Kearns WH, editor. Welding Handbook Volume 2: Welding Processes - Arc and Gas Welding and Cutting, Brazing, and Soldering. Miami, FL: American Welding Society. p. 459-516. ISBN 0-87171148-6.

Sriram K, Lin GX, Jefferson AM et al. (2015) Modifying welding process parameters can reduce the neurotoxic potential of manganese-containing welding fumes. Toxicology; 328 : 168-178.

Stephenson D, Seshadri G, Veranth JM. (2003) Workplace exposure to submicron particle mass and number concentrations from manual arc welding of carbon steel. Am Ind Hyg Assoc J; 64: 516-521. 
Tashiro S, Zeniya T, Yamamoto K et al. (2015) Numerical analysis of fume formation mechanism in TIG welding. Weld Int; 29: 165-172.

Vincent JH, Brosseau LM. (1995) The nature and properties of workplace airborne contaminants. In Harrington JM, Gardiner K, editors. Occupational Hygiene. Oxford: Blackwell Science Ltd. p. 61-83. ISBN 0-632-03734-2.

Win-Shwe TT, Fujimaki H. (2011) Nanoparticles and Neurotoxicity. Int J Mol Sci; 12: 62676280.

Zeidler-Erdely PC, Erdely A, Antonini JM. (2012) Immunotoxicology of arc welding fume: Employee and experimental animal studies. J Immunotoxicol; 9: 411-425. 


\section{CHAPTER 2: LITERATURE REVIEW}

In Chapter 1 a brief overview was provided to outline the research topic presented in this study. In Chapter 2 the important key points of the study will be discussed in further detail. A more in-depth look will focus on metal fumes, airborne particulate matter and the characterisation thereof. The respiratory deposition of particulate matter and metal fumes will be elaborated on.

\subsection{Particle size characterisation}

The occupational health community has established biologically relevant size fractions and these fractions can be characterised according to their entrance and/or deposition in the different setions of the respiratory system. These fractions are classified into the inhalable, thoracic and respirable fractions according to the difference in the particle size diameters (Cherrie and Aitken, 1999; Wilson et al., 2002; Notø et al., 2016).

The inhalable size fraction of airborne particulate matter is defined as the fraction of particles which enters the respiratory system through the upper airways (nose and mouth) and can be hazardous to human health when they are deposited anywhere in the respiratory tract. This fraction has an aerodynamic diameter of less than $100 \mu \mathrm{m}$. However, due to their larger size fraction, most of these particles will deposit in the nose and mouth. This fraction includes all particle sizes namely thoracic, respirable and nano-sized particles (Lynch, 2000; Wilson et al., 2002; Cheng and Su, 2013).

The thoracic fraction is the size fraction of airborne particulate matter that travels past the larynx to deposit anywhere in the lung airways or the gas exchange regions of the deep lung, and these particles will mainly deposit in the ciliated bronchial passages. This fraction has an aerodynamic diameter of less than $10 \mu \mathrm{m}$. This fraction includes all particles with an aerodynamic diameter of up to $10 \mu \mathrm{m}$; therefore, also respirable and nano-sized particles (Reist, 2000; Vincent, 2007; Brown et al., 2013).

The respirable fraction particles will penetrate to the unciliated airways and are more likely to reach the gas exchange region of the deep lung and deposit there and may be absorbed into the alveoli of the lungs. This size fraction is smaller than $4 \mu \mathrm{m}$ in diameter and includes nanoparticles, which will be discussed in the following section (Petavratzi et al., 2005; Vincent, 2007; Cheng and Su, 2013).

Particles in the respirable fraction size are of great importance owing to the fact that they are considered more toxic than larger particles of the same chemical composition. Respirable 
fraction particles pose the greatest hazard to health as they have the ability to penetrate to the deep structures of the lungs and deposit there and due to the fact that these particles are removed very slowly from the respiratory system (Brown et al., 2002; Moroni and Viti, 2009; Kang et al., 2011; Sriram et al., 2015).

\subsection{Nanoparticles}

Nanoparticles (NPs) can be defined as particles measured in nanometres (nm) and are in the submicron range, however, most studies refer to nanoparticles as particles that have at least one external dimension in the range of 1 to $100 \mathrm{~nm}$ (Shaffer and Rengasamy, 2009; Win-Shwe and Fujimaki, 2011; Chang et al., 2013; Oberdörster et al., 2013; Andujar et al., 2014). Nanoparticles are very unique as they are small in size, have a large surface area per unit volume and are therefore highly reactive (e.g. as a catalyst), increasing toxicological activity (Kang et al., 2011; Chang et al., 2013; Tokar et al., 2013). Various studies have indicated that nanoparticles have greater biological/toxicological activity and may be more hazardous than larger-scale particles (Pui et al., 2008; Schulte et al., 2009). In an occupational setting, the most important route of exposure to nanoparticles is through inhalation; however, these particles may also penetrate the dermal layers or cause contact dermatitis or sensitisation (Kang et al., 2011; Bepko and Mansalis, 2016). After inhalation, these particles move through the respiratory system and will deposit and be absorbed in the alveoli region of the lungs (lavicoli et al., 2013).

Nanoparticles elicit a stronger toxic response than larger-scale particles due to their ability to escape the lungs and to be absorbed into the blood circulation. Once in the circulation, migration throughout the body takes place and target organs are easily reached, bringing about toxic effects in various other regions of the body (Kang et al., 2011; Nilsson et al., 2013; Oberdörster et al., 2013). Larger particles will only be able to escape the lungs and be absorbed into the blood or lymphatic circulation under heavy overload conditions, which rarely occurs (Oberdörster et al., 2013). These unique characteristics of nanoparticles may be challenging when addressing the risks and potential health effects and impact of nanoparticles (Maynard and Kuempel, 2005).

\subsection{Physical and chemical characteristics of particulate matter}

The physical characteristics include the particle size, shape, concentration of particles in the air, surface area of the particles and the aerodynamic diameter of the particles. The aerodynamic diameter can be defined as the diameter of a unit density microsphere with the same terminal velocity as the particle in question (McClellan, 2002; Wilson et al., 2002; 
Sriram et al., 2015). Some of the chemical characteristics include the surface composition, solubility of the particles, elemental phase and the most relevant for this study, the metal composition of the particles (Kim and Hu, 2006; Sriram et al., 2015).

When respirable or nanoparticles collide while airborne, they will adhere to one another and form larger clusters of particles, called agglomerates. This growth process is known as coagulation. This process does not necessarily cause a change in the particle mass concentration. Conversely, it does cause a shift in the particle size distributions as well as the shape of clusters of particles which will determine if and where they deposit in the respiratory tract (Reist, 2000; Nazaroff, 2004; Zeidler-Erdely et al., 2012; Hariri et al., 2014).

Therefore, the aerodynamic diameter and particle size as well as the metal composition of particles, are important in order to determine the risk of causing adverse health effects in humans (Pickford and Davies, 2007; Sriram et al., 2015). In this study the focus will be on the particle size fraction as well as the metal composition of the particulate matter present in metal fumes.

\subsection{Health effects}

The health effects associated with particulate matter, including nanoparticles, may be exacerbated when exposed to metal fumes. Therefore, it is important to consider the health effects associated with particulate matter, nanoparticles as well as metal fumes (Riley et al., 2003; Schaumlöffel, 2012; Sriram et al., 2015). These health effects will be conferred in short in this section.

\subsubsection{Health effects associated with particulate matter}

The region where particles will deposit in the human respiratory tract will determine the pathogenic potential of inhaled particulate matter (Brown et al., 2013).

Particulate matter inhalation may lead to acute respiratory health effects, which may cause instantaneous health problems such as irritation of the airways or chronic respiratory health effects, that may take years to develop symptoms such as chronic bronchitis (Pickford and Davies, 2007). Some particulate matter may also be sensitisers, which is defined as a chemical or particulate matter causing an allergic reaction to the respiratory airways or the skin following repeated exposure to this chemical or particle and may lead to exacerbation of symptoms (Pickford and Davies, 2007; Health and Safety Executive (HSE), 2010). These allergic reactions may cause occupational asthma (Petavratzi et al., 2005). Irritation, inflammation and damage to the lungs may also occur, causing obstructive changes in the 
pulmonary function as well as chronic bronchitis (mainly caused by particles in the thoracic size fraction), which may result in emphysema. It may also cause pneumoconiosis and possibly lung cancer (mainly caused by respirable particles) (Cherrie and Aitken, 1999; Petavratzi et al., 2005; Kim and Hu, 2006; Brown et al., 2013).

The eyes, skin and respiratory tract of employees may be exposed to particles when working in close proximity to methods releasing particles and this could lead to damage of the skin through dermatitis, and may also lead to eye, nose and throat impairment (Petavratzi et al., 2005). Particulate matter may also play a part in cardiovascular health effects, with more cardiovascular deaths associated with small increases in airborne particulate levels. An association is shown between an elevation in particulate levels, an increase in heart rate as well as the onset of acute myocardial infarction. The physiology of the cardiovascular system may be affected by particles, causing changes in the brachial artery diameter, heart rate variability and these changes may lead to ischaemic heart diseases (Donaldson et al., 2005; Petavratzi et al., 2005).

\subsubsection{Health effects associated with nanoparticles}

Nanoparticles have various adverse health effects although most of these effects are still being investigated as the toxicological mechanisms behind some of these health effects are unknown or unclear (lavicoli et al., 2013). The adverse effects are caused by the ability of nanoparticles to escape the lungs and be absorbed into the bloodstream and to translocate to secondary target organs (Donaldson et al., 2005). Some of these health effects include high lung deposition, cardiovascular effects, inflammation, impairment of the immune system, neurodegenerative diseases, pulmonary diseases and inflammation, aggravated asthma and chronic bronchitis (Win-Shwe and Fujimaki, 2011; lavicoli et al., 2013; Andujar et al., 2014; Behera et al., 2015). Due to their small size, nanoparticles may enter cells and cell organelles which can cause damage to the mitochondrial membranes. This will cause oxidative stress and may lead to an increase in apoptosis (cell death) (Schulte et al., 2009). Nanoparticles depositing in the nasal region may be translocated to the central nervous system by way of the olfactory nerve (nerve supplying the smell receptors) and may cross the blood-brain barrier into the brain (Pui et al., 2008; Krug and Wick, 2011).

\subsubsection{Health effects associated with metal fumes}

The inhalation of metal fumes may cause acute and chronic health effects (Persoons et al., 2014). Acute adverse health effects may include metal fume fever, airway irritation, a decrease in lung function and skin and eye irritation (Lee et al., 2007; La Vecchia and Maestrelli, 2011; 
Persoons et al., 2014). Bronchitis, pneumoconiosis (lung disease caused by inhalation of particulate matter), asthma, obstructive pulmonary disease (lung disease causing difficulty breathing), pneumonitis, pulmonary fibrosis, pneumonia, emphysema, neurological dysfunction (manganism; possibly caused by manganese fumes), an increased risk of heart disease and an increase in the prevalence of lung cancer and laryngeal cancer are possible chronic health effects (Antonini, 2003; Lee et al., 2007; Wittczak et al., 2009; La Vecchia and Maestrelli, 2011; Persoons et al., 2014, American Lung Association, 2015; American Thoracic Society, 2015; Fethke et al., 2015; Sriram et al., 2015).

Metal fume fever presents with flu-like symptoms and may be characterised by fever, chills, coughing, nausea, chest pain and muscle soreness (Tokar et al., 2013). Pulmonary fibrosis is characterised by scarred and damaged lung tissue which causes a decrease in lung function (Leikauf, 2014). Employees exposed to metal fumes may be more susceptible to pulmonary infections and diseases (Moroni and Viti, 2009; Zeidler-Erdely et al., 2012).

The health effects of different metals will be discussed in full in Section 2.9.

\subsection{Particle size-selective sampling}

An adult inhales roughly 10000 litres of air per day in order to exchange oxygen and carbon dioxide during respiration. The inhaled air contains varying sizes of particles that may reach different regions of the respiratory tract and have the ability to cause adverse health effects by depositing there (Lever and Schroter, 1995; Brown et al., 2013).

Particle size-selective sampling is defined as the health-related method for the collection of varying sizes of airborne particles. It is based on the penetration and deposition of particles in different regions of the respiratory tract and is very important in the identification of health risks due to exposure within an occupational setting (Lippmann, 1999; Brown et al., 2013; Cheng and $\mathrm{Su}, 2013)$.

During the 1920s, hygienists started using count-based methods and particles were collected in 1 litre water-filled impingers by hand operated pumps. The particles smaller than $10 \mu \mathrm{m}$ were then counted by the hygienist by using an optical microscope to determine the particle fraction that was thought to be toxicologically relevant (Kelly, 2002; Vincent, 2007). The particle shape and composition could also be inspected by using this approach (Vincent, 2007).

Particle-number sampling to determine full-shift time-weighted average (TWA) was used during the 1950s by collecting samples near representative employees or at strategic sampling 
positions (Lippmann, 1999). Then, in the 1960s, hygienists started using mass-based sampling methods and the personal sampling pump was developed. The development of the personal sampling pumps connected to a plastic cassette containing a filter made it possible to sample individual employees for a prolonged period of time. These samples could then be assessed for their total mass as well as the chemical composition of the particles present on the filter (Lippmann, 1999; Sleeth, 2013). During the 1970s and onwards, full-shift personal sampling was emphasised as it is considered by most hygienists to be the most accurate approach to provide the best approximation of employee exposure (Lippmann, 1999).

In 1913 it was concluded that not all sizes of particles were equally biologically relevant owing to the fact that researchers found particles smaller than $7 \mu \mathrm{m}$ in the lungs of South African miners (Sleeth, 2013). During the 1950s, the sampling for the respirable particle fraction was recommended, which was defined as the fraction that can reach and deposit in the alveolar region of the lungs and these particles were thought to be smaller than $5 \mu \mathrm{m}$ in diameter but could be as large as $10 \mu \mathrm{m}$ (Sleeth, 2013). Only in the 1980s, was the theory of inhalable particles being discussed and did researchers understand that all particles up to $100 \mu \mathrm{m}$ in diameter, that can be inhaled by the nose or mouth may also be important to take into consideration (Sleeth, 2013).

In 1983, the International Standards Organisation (ISO) was the first to establish various particle size-selective criteria, composed of inhalable, thoracic and respirable fractions and also developed a separate criterion for respirable dust for community and occupational exposures (Lippmann, 1999). During this time, there was agreement on the definition of the different particle size fractions according to their diameter. The American Conference of Governmental Industrial Hygienists (ACGIH), the Comité Européen de Normalisation (CEN) and ISO adopted these definitions and this inspired the development of most of the particle size-selective sampling methods which are still used to this day, as illustrated in Figure 1 (Brown et al., 2013; Sleeth, 2013). 


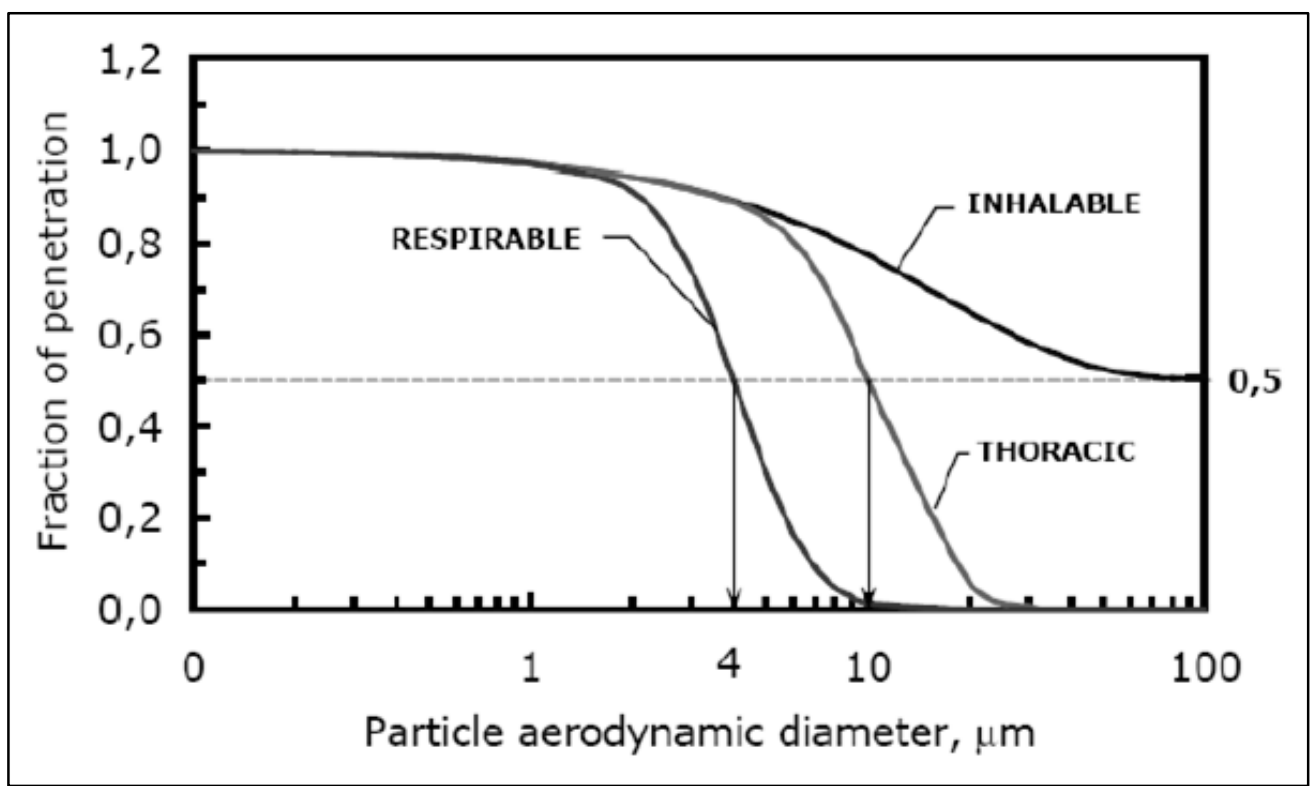

Figure 1: ISO/CEN/ACGIH sampling conventions for health related particle fractions (Sánchez-Jiménez et al., 2011).

There are various samplers that may be used during sampling of particulate matter. The inhalable fraction size samplers include the Institute of Occupational Medicine (IOM) sampler, closed-face/open-face filter cassette (CFC/OFC) sampler (in 25 and $37 \mathrm{~mm}$ ), Total Dust Sampling System (GSP) sampler, Seven-hole sampler, Conical Inhalable sampler (CIS), Button sampler, to name a few (Li et al., 2000; Skaugset et al., 2013; Kock et al., 2015).

The thoracic and respirable fraction size samplers may include Parallel Particle Impactor (PPI), SKC aluminium cyclone, GK2.69 cyclone, Personal Cascade Impactor sampler (PCIS), FSP10 sampler as well as the CIP 10-R sampler. Some of these samplers may be used to sample either thoracic or respirable size fractions by using different flow rates, such as the GK2.69 cyclone and the PPI (Giorio et al., 2013; SKC Inc, 2013; SKC Inc, 2014; Stacey et al., 2014).

A sampler was developed to sample for the nano-sized fraction of particulate matter as methods that are currently used do not distinguish between the nano-sized fraction and particles that are larger in diameter. This sampler is known as the Nanoparticle Respiratory Deposition (NRD) sampler (Cena et al., 2011; Cena et al., 2014).

The RespiCon was also used to sample for all three inhalable, thoracic and respirable fraction sizes, however this sampler was discontinued in 2008 owing to the fact that it showed only reasonable accuracy and was not precise enough (Koch et al., 2002; TSI Inc, 2015). 
For this study the IOM sampler, GK2.69 cyclone sampler, SKC aluminium cyclone sampler, NRD sampler as well as the open-face $37 \mathrm{~mm}$ filter cassette sampler were chosen. The IOM and SKC aluminium sampler were chosen because of availability as well as accuracy (DEPA, 2008). The GK2.69 cyclone sampler is accurate and conforms to the European and US standards for the thoracic curve and was therefore chosen (BGI Inc, 2007). The NRD sampler is one of the few samplers with the ability to sample for only nanoparticles and was chosen because of the need to distinguish between the nano-sized fraction and particles that are larger in diameter (Cena et al., 2014). The open-faced filter cassette was selected owing to the fact that the distribution of particulate matter on the filter is optimal for determination of the particle size distribution range (Kenny et al., 1999).

The methodology for using these samplers will be discussed in Chapter 3.

\subsection{Deposition of airborne particulates in the respiratory tract}

The site of deposition of inhaled particles is influenced by the particle size and particles will deposit in the respiratory system when they come into contact with an airway surface (Thomas et al., 2008; Méndez et al., 2010). The depth to which particles will penetrate is determined by the particle's shape, size, chemical composition and the physiological characteristics of the individual (McClellan, 2002; Maynard and Kuempel, 2005; Trakumas and Salter, 2009; Oberdörster et al., 2013). Physiological characteristics differ from one individual to another and include lung anatomy, lung capacity, lifestyle differences and genetics (Kuempel et al., 2001; Sleeth, 2013). This difference in individuals may influence the retention or clearance of particles in the respiratory system (Kuempel et al., 2001).

\subsubsection{Respiratory regions and particle deposition}

Particle size determines the possibility that the particle will enter the respiratory system, where it will deposit as well as how it will be removed or cleared from the respiratory tract (Maynard and Kuempel, 2005).

The respiratory tract comprises three main compartments: the nasopharyngeal region (referred to as Nasal in Figure 2) which includes the area from nose/mouth to larynx, the tracheobronchial region (referred to as TB in Figure 2) which includes the area from the larynx to the terminal bronchioles and the alveolar region (referred to as Alveolar in Figure 2), which includes the area from the respiratory bronchioles to the alveolar ducts (Vincent, 2007; Oberdörster et al., 2013). 
Particles will firstly reach the nasopharyngeal region after inhalation and this region is the most effective region to remove/capture inhaled agglomerated particles from the air (Vincent, 2007; Tian et al., 2016). Large particles will settle in the nose or throat and are mainly deposited by inertial impaction and gravitational sedimentation (Oberdörster et al., 2005; Kim and Hu, 2006; Vincent, 2007). Large particles are deposited by inertial impaction on airway surfaces where the airway direction changes and gravitational sedimentation is the settling of particles due to gravity (Martin and Finlay, 2006; Vincent, 2007; Yang et al., 2008). Smaller particles are mainly deposited by diffusion and possibly electrostatic forces (Vincent, 2007). Diffusion is the dispersion over a surface due to random Brownian movements which causes particulate matter to relocate from the airstream to the surface of the respiratory tract and electrostatic force is the attraction or the repelling of particles due to their electric charges (Widmaier et al., 2008; Schröder, 2014).

Inhalable particles enter the main airways and will be deposited anywhere in the respiratory tract. Thoracic particles are mostly collected in the upper airways and are deposited in the lung airways as well as the gas-exchange region of the lungs. The respirable fraction of particles penetrates to the alveolar region of the lungs (Wilson et al., 2002; Pickford and Davies, 2007).

Particles with a diameter of less than $100 \mathrm{~nm}$ (nanoparticles) are mainly deposited in the respiratory tract through diffusion due to displacement when colliding with air molecules in the airways (Oberdörster et al., 2005; Sung et al., 2007; Tian et al., 2016). Almost all of these particles will move through the nasopharyngeal region/barrier and will penetrate to the deepest structures of the lungs (Tian et al., 2016). Approximately $50 \%$ of inhaled $20 \mathrm{~nm}$ particles will deposit in the alveolar region of the lungs, whereas approximately $15 \%$ will deposit in the tracheobronchial region as well as the nasopharyngeal region (Oberdörster et al., 2005). The $1 \mathrm{~nm}$ particles are too small and too light to be carried to the deep lung structures and are therefore easily exhaled and are minimally deposited (Yang et al., 2008). Therefore, approximately $90 \%$ of inhaled $1 \mathrm{~nm}$ particles will deposit in the nasopharyngeal region, $10 \%$ in the tracheobronchial region and basically zero particles will deposit in the alveolar region, as illustrated in Figure 2 (Oberdörster et al., 2013). 


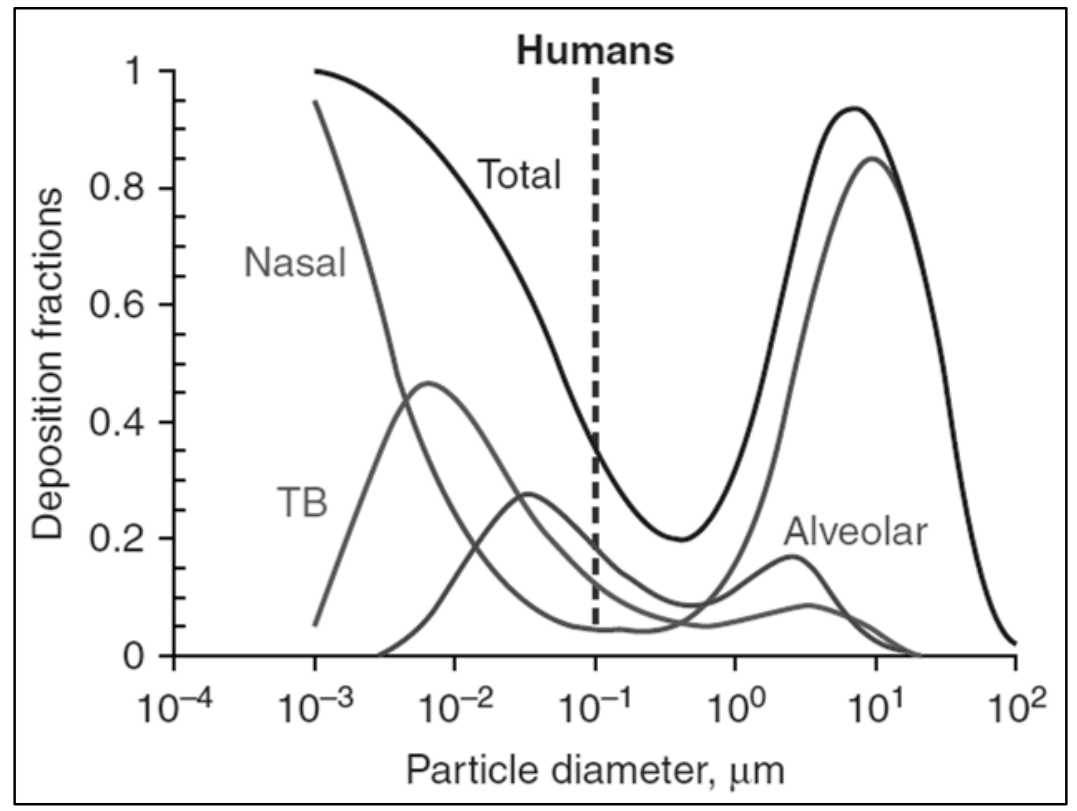

Figure 2: $\quad$ Model predictions of deposition fractions for different particle sizes in humans. Nano-sized particles are left of the dashed line $(<100 \mathrm{~nm})$ and particles in the micrometre range are on the right side if the dashed line (Oberdörster et al., 2013).

The human lungs possess various lung clearance and defence mechanisms to manage and keep airway surfaces free from inhaled particles (Maynard and Kuempel, 2005; Oberdörster et al., 2005). These mechanisms also have some limitations (Maynard and Kuempel, 2005). These clearance and defence mechanisms are discussed in the following section.

\subsubsection{Respiratory defence mechanisms (clearance)}

The clearance of particles from the respiratory tract depends on the site of particle deposition (Méndez et al., 2010). Particles inhaled through the nose or mouth, which are deposited in the upper respiratory tract, are swiftly cleared by the coughing mechanism which can be defined as the intake of an involuntarily large breath and then the air is expelled from the lungs with respiratory muscular effort (Eschenbacher et al., 2000; McClellan, 2002; Widmaier et al., 2008).

Particles that are deposited in the anterior area of the nasopharyngeal region could be cleared by blowing the nose. Particles deposited in the posterior area may be cleared by the cilia (hairlike projections) moving in an upward direction by which the particles will reach the epiglottis and will eventually be swallowed and enter the gastrointestinal (GI) tract, remaining there until absorbed or excreted. Particles not deposited in the nasopharyngeal region will move through 
the larynx and will enter the lungs (Vincent, 2007). In the tracheobronchial region of the lungs, particles will be swiftly cleared by the mucociliary escalator by which particles are caught in mucous secreted by cells in the airways and are moved upwards towards the larynx through cilia moving in a rhythmic upward direction, where it can be expectorated or swallowed and enter the GI tract (Eschenbacher et al., 2000; Pickford and Davies, 2007; Vincent, 2007).

The particles that move through the tracheobronchial region (mainly respirable particles) will be deposited in the alveolar region from which they are very slowly removed by scavenging alveolar macrophages, present on the alveolar walls, which engulf and phagocytise the particles. Alternatively, these particles may not be removed at all. (Kelly, 2002; Oberdörster et al., 2005; Vincent, 2007). The engulfed particles may be carried upwards, back to the tracheobronchial region and the mucociliary escalator and will then be moved onwards by the beating cilia of the escalator and eventually swallowed (Maynard and Kuempel, 2005; Oberdörster et al., 2005; Vincent, 2007). The clearance of particles through scavenging alveolar macrophages from the alveolar region is much slower than other clearance mechanisms and the efficiency of this mechanism depends on the ability of the macrophages to sense the particles deposited in the region (Oberdörster et al., 2005; Vincent, 2007). Phagocytised particles that remain in the alveolar region may cause macrophages to undergo lysis and cause pulmonary inflammation (Kuempel et al., 2001).

Aggregated or agglomerated nanoparticles are also cleared by the scavenging alveolar macrophages and carried upwards towards the tracheobronchial region and the mucociliary escalator, where they are removed by the moving cilia and eventually swallowed (LehmanMcKeeman, 2013; Oberdörster et al., 2013). Nanoparticles deposited as single particles are too small to be recognised by the scavenging alveolar macrophages and are also too small to be phagocytised and thus the clearance of single nanoparticles in the lung is poor (Oberdörster et al., 2013). Nanoparticles and micro-particles are distinguished by the translocation of nanoparticles into the blood circulation. Nanoparticles may be eliminated from the body through faeces and urine and particles that are not eliminated may accumulate in the liver, spleen and bone marrow (Oberdörster et al., 2013).

\subsection{Metal cutting methods}

Metal cutting can be defined as a process to sever metals or to remove one metal from another and can be done by means of two main processes: arc cutting and oxygen cutting (Sasse et al., 1978; Lyndon and Platcow, 2011). Arc cutting defines a group of cutting processes where a metal is heated until it begins to melt in order to cut the metal with an arc between the metal and an electrode, also known as gouging. Oxygen cutting defines a group 
of cutting processes where metals are separated or removed through the high temperature exothermic reaction of pure oxygen with the base metal, also known as lancing (Sasse et al., 1978; Lyndon and Platcow, 2011). Gouging is not dependent on oxidation reactions and therefore it can separate metals that the lancing process cannot separate (Thomas, 2013).

\subsubsection{Gouging process}

Gouging is used for the preparation of the weld groove or for the removal of defective welding zones and is done by melting the base metal with an electric arc and the removal of the molten metal through a strong jet of compressed air (Sasse et al., 1978; Lyndon and Platcow, 2011). The compressed air passes through the arc to remove the melted metal to create a gouge or cut in the metal (Lyndon and Platcow, 2011).

The electric arc is made of carbon-graphite and is coated with a thin layer of copper that is referred to as direct-current (DC) copper coated electrodes and is the most widely used type of electrodes (Sasse et al., 1978; Lyndon and Platcow, 2011). There are other types of electrodes such as DC plain electrodes and alternating current (AC) copper coated electrodes although these are not widely used because of limitations, such as erosion and short electrode life (Sasse et al., 1978; Lyndon and Platcow, 2011). The DC copper coated electrodes are used due to their stable characteristics, groove uniformity and long electrode life in comparison with other electrodes, and the copper coating improves the conductivity and operation efficiency (Sasse et al., 1978). These electrodes are consumed during the cutting process, because of the loss of carbon through oxidation or sublimation (Sasse et al., 1978).

Gouging produces fumes that can potentially be hazardous to human health (Thomas, 2013). The gouging process is mostly applied to gouge or sever low alloy steel, mild steel, carbon steel and stainless steel as well as cast iron (containing more than $2 \%$ carbon) and also copper, magnesium, aluminium and nickel alloys. Therefore, the following metals may be present in the fumes generated during the gouging process: aluminium (Al), chromium ( $\mathrm{Cr}$ ), copper $(\mathrm{Cu})$ (also emitted during the consuming of the copper-coated electrodes), iron (Fe), magnesium (Mg), manganese (Mn), molybdenum (Mo) and nickel (Ni) (Sasse et al., 1978; Cary, 1989; Total Materia, 2001; Atlas Foundry Company, 2010). The health effects of these metals will be discussed in Section 2.9.

\subsubsection{Lancing process}

Lancing severs or removes metal by the chemical reaction of pure oxygen with a base metal such as chromium, iron, manganese, nickel as well as different types of steel (Sasse et al., 1978; Cary, 1989; Lyndon and Platcow, 2011). This cutting process begins by the heating of 
a small area on the metal with an oxy-fuel flame (Muñoz-Escalona et al., 2006). The hollow lancing rod reacts with the oxygen that flows through the centre of the rod and this causes an oxidation reaction. This oxidation reaction releases heat which causes melting of the metal (Wang et al., 2004). The fuel gas used during lancing is acetylene and it reacts with oxygen to generate preheat flames (oxygen-fuel gas flame) that are used to heat the metal to a temperature where the metal will react with the oxygen. Acetylene is widely used because of its advantages, such as availability and high flame temperature (Sasse et al., 1978; Lyndon and Platcow, 2011).

Oxygen purity of $99.5 \%$ or higher is required during lancing as lower values may reduce the efficiency of the operation since the quality of cutting will be impaired or might not be able to be performed at all (Sasse et al., 1978). The oxygen stream performs the actual cutting operation and is able to cut through virtually any material (Sasse et al., 1978; Cândea et al., 2009).

A few of the advantages of lancing includes the ease with which the method can be applied. It is inexpensive and shows high precision with regard to cutting holes, the method does not result in noise or shock and vibration is low. It can be performed within small spaces, and it can be used to cut through both metal and concrete (Wang et al., 2004). A disadvantage of this cutting method is the release of a large amount of fumes and therefore, it is important to control the exposure of employees to these metal fumes (Wang et al., 2004).

The lancing process is mostly applied to remove or sever iron, rust, cast iron as well as low alloy steel, high alloy steel, carbon steel and stainless steel. Therefore, the following metals may be present in the fumes generated during the lancing process: chromium ( $\mathrm{Cr}$ ), iron ( $\mathrm{Fe})$ (also emitted during the consuming of the lancing rod), manganese (Mn), molybdenum (Mo) and nickel (Ni) (Sasse et al., 1978; Cary, 1989; Total Materia, 2001; Atlas Foundry Company, 2010). The health effects of these metals will be discussed in Section 2.9.

\subsection{Metal fumes}

Metal fumes or vapours are formed when a volatilised solid is cooled down to ambient temperatures. Consequently, the volatilised solid condensates, creating a fume or vapour consisting of metal oxide particles (Mohan et al., 2014; Tashiro et al., 2015). The particles in the fume are extremely fine and usually have an aerodynamic diameter of less than $1 \mu \mathrm{m}$ (Plog 2002, Mohan et al., 2014). These fine particles may then coagulate (collision of smaller particles to form larger agglomerates) to form larger clusters of particles (secondary particles), that are several microns in diameter (Zeidler-Erdely et al., 2012; Tashiro et al., 2015). 
Metal fumes are usually generated through different methods of welding and thermal cutting operations (Pickford and Davies, 2007). Several hazards are associated with welding and cutting methods of which the fumes liberated during these operations are considered to be the most dangerous (Mohan et al., 2014). Welding and cutting fumes comprise a complex mixture of several toxic metals. The inhalation thereof may lead to adverse health effects. Toxic metals may include the following: cadmium (Cd), chromium (Cr), cobalt $(\mathrm{Co})$, iron (Fe), lead $(\mathrm{Pb})$, manganese (Mn), nickel (Ni), titanium (Ti), vanadium (V) and zinc (Zn) (Hartmann et al., 2014; Persoons et al., 2014; Sriram et al., 2015).

Metal fumes usually fall in the respirable and nanometre fraction size range (Mohan et al., 2014). As elaborated on in earlier sections, these fraction sizes may lead to a variety of health effects (Mohan et al., 2014). The health effects of the most prominent metals are discussed in the following section.

\subsection{Different metals and health effects}

Metals with the most adverse health effects are elaborated on in this section. Metals that have less severe health effects are listed in a table with their most important health effects.

The following table outlines the IARC classification groups (International Agency for Research on Cancer) and is also used to classify the different metals (IARC, 2016):

Table 1: IARC classification system (IARC, 2016).

\begin{tabular}{|l|l|}
\hline Group & Classification \\
\hline Group 1 & Carcinogenic to humans \\
\hline Group 2A & Probably carcinogenic to humans \\
\hline Group 2B & Possibly carcinogenic to humans \\
\hline Group 3 & Not classifiable as to its carcinogenicity to humans \\
\hline Group 4 & Probably not carcinogenic to humans \\
\hline
\end{tabular}

\subsubsection{Aluminium}

Aluminium (Al) may be present in the base metals (metal object that gouging or lancing is performed on). Therefore, aluminium may be present in the fumes emitted from the gouging and lancing processes (Sasse et al., 1978; Atlas Foundry Company, 2010). Aluminium is the most abundant natural metal present in the earth's crust and is mainly used in alloys (Firth, 
2007; Tokar et al., 2013). Aluminium shows very little acute toxic effects, however, chronic exposure to aluminium may possibly cause the development of lung fibrosis, chronic bronchitis, pneumoconiosis (aluminosis) and granulomatous lung disease and may possibly cause neurologic disorders (Taiwo, 2005; Firth, 2007; Tokar et al., 2013).

Aluminium is classified as a Group 1 carcinogen and shows an increased risk for lung and bladder cancer (IARC, 2012b). People working in aluminium welding, the processing of aluminium and in industries that manufacture aluminium products are possibly the largest group of people occupationally exposed to aluminium fumes (Agency for Toxic Substances and Disease Registry (ATSDR), 2011a). People in these occupations usually develop pneumoconiosis, bronchitis and lung fibrosis (Riihimäki and Aitio, 2012; Hartmann et al., 2014).

\subsubsection{Antimony}

Antimony ( $\mathrm{Sb}$ ) may be present in base metals as an alloy and may therefore also be emitted during gouging and lancing processes (Cooper and Harrison, 2009; Stanton, 2014). Antimony is a silvery and brittle metalloid (Royal Society of Chemistry, 2016a). The inhalation of antimony fumes may lead to irritation of the lungs, skin, eyes and mucous membranes as well as the development of acute pulmonary oedema, chronic bronchitis, emphysema, obstructive lung disease, cardiac arrhythmias and heart, lung and gastrointestinal diseases. A form of pneumoconiosis, known as antimoniosis, may also develop due to the exposure to antimony fumes (Cooper and Harrison, 2009; Tokar et al., 2013).

Antimony is classified as a Group 2B carcinogen for lung cancer (IARC, 1989). Workers working in industries manufacturing antimony as well as mining, smelting and refining processes of metals may have the highest exposure to antimony fumes and may lead to the development of antimoniosis, cardiac arrhythmias as well as lung irritation (Cooper and Harrison, 2009; Sundar and Chakravarty, 2010).

\subsubsection{Arsenic}

Arsenic (As) may be present as a by-product or an alloy in base metals and may be liberated during gouging and lancing (Centres for Disease Control and Prevention (CDC), 2011). Arsenic is a highly toxic metalloid and has been known for a long time as the "poison of kings and the king of poisons" (Tokar et al., 2013). Exposure to arsenic may cause numbness of extremities, conjunctivitis, cardiac arrhythmia, damage to the mucous membranes, changes in the skin epithelium, liver damage, muscle cramping, neurological effects such as sensory 
loss and peripheral neuropathy and may be associated with the development of diabetes (World Health Organization (WHO), 2010; WHO, 2012; Tokar et al., 2013).

Arsenic is classified as a Group 1 carcinogen for lung, bladder, kidney, liver, skin and prostate cancer (IARC, 2012a). Mining maintenance workers may be categorised under the highest exposed workers during lancing processes and arsenic exposure may lead to the development of lower and upper respiratory tract irritation as well as central nervous system disorders (Jumpponen et al., 2014; United States Department of Labor, 2015).

\subsubsection{Chromium}

Chromium ( $\mathrm{Cr}$ ) is present in the base metals that work is performed on and therefore, may be present in the fumes emitted from the gouging and lancing processes (Sasse et al., 1978; Atlas Foundry Company, 2010; Stanton, 2014). Chromium metal, obtained from chromite ore, is a hard, grey metal and has various industrial applications which are used in welding rods and as an alloy in stainless steels (Firth, 2007). Chromium exists in different valence states; such as trivalent chromium $(\mathrm{Cr}(\mathrm{III}))$ and hexavalent chromium $(\mathrm{Cr}(\mathrm{VI}))$, where trivalent chromium is an essential nutrient and hexavalent chromium is a known human carcinogen (Group 1) (Franzblau and Garabrant, 2005a; IARC, 2012a; Tokar et al., 2013; Keane, 2014; Yu et al., 2014). Chromium metal and trivalent chromium may possibly lead to respiratory tract irritation, dermatitis, acute bronchoconstriction and skin irritation. Hexavalent chromium may lead to ulceration and perforation of the nasal septum, asthma, ulceration of skin surfaces and sensitisation of the skin (Franzblau and Garabrant, 2005a; Firth, 2007; Tokar et al., 2013; Yu et al., 2014).

Although $\mathrm{Cr}(\mathrm{VI})$ can be converted to $\mathrm{Cr}(\mathrm{III})$ in the human body, this process should not be relied upon to eliminate all $\mathrm{Cr}(\mathrm{VI})$ from the body, as this process can be variable and may not convert all $\mathrm{Cr}(\mathrm{VI})$ to $\mathrm{Cr}(\mathrm{III})$ (Costa, 2003). Hexavalent chromium is classified as a Group 1 carcinogen and shows an increased risk for cancer of the lung, nose and nasal sinuses, whereas trivalent chromium is classified as a Group 3 carcinogen (IARC, 2012a). Workers in the chemical manufacturing or chromate-containing pigment manufacturing industries and welders are possibly the largest group of workers occupationally exposed to chromium and these people may develop respiratory tract irritation, asthma, dermatitis as well as lung and nose cancer (United States Department of Labor, 2015).

\subsubsection{Cobalt}

Cobalt (Co) is generally in combination with other metals and is used as an alloy in a base metal. Therefore, it can be liberated during gouging and lancing processes (CDC, 2013). 
Cobalt is an essential and relatively rare element and is therefore, also rare in the working environment (Firth, 2007). Cobalt is a magnetic and hard metal (Kreiss, 2005). Cobalt fume exposure may potentially lead to shortness of breath, coughing, respiratory irritation, sinusitis, bronchitis and asthma. Furthermore, exposure to these fumes may lead to the development of pneumonitis, pulmonary disease, decreased lung function, hard metal lung disease, which is a type of pneumoconiosis (progressive pulmonary interstitial fibrosis), cardiomyopathy and ischaemic heart disease (National Occupational Health and Safety Commission (NOHSC), 1990; Kreiss, 2005; Firth, 2007; Tokar et al., 2013; Klasson et al., 2016).

Cobalt is a possible human carcinogen (Group 2B) causing lung cancer (IARC, 1991; Kreiss, 2005; IARC, 2006a). Workers are mostly exposed to cobalt fumes when working in industries that manufacture or make use of cobalt metal as well as when working in the mining, smelting and processing of metals and in alloy production and exposure may lead to the development of asthma, hard metal lung disease and a decrease in pulmonary function (ATSDR, 2004; CDC, 2013).

\subsubsection{Iron}

Iron (Fe) is present in the base metals work is performed on and consequently, in the fumes emitted from gouging and lancing processes. Iron is also emitted during the consuming of the lancing rod (Sasse et al., 1978; Total Materia, 2001). Iron is an element which is essential to human health in terms of blood oxygenation. Iron is a greyish, hard and brittle metal which is used as an alloy in steel (Blaszczak-Boxe, 2015; Royal Society of Chemistry, 2016b). The inhalation of iron may lead to iron oxide particle deposition in the lungs. This deposition resembles silicosis - and is called siderosis - and is a benign form of pneumoconiosis (NOHSC, 1990; Tokar et al., 2013). Iron fumes may also lead to metal fume fever (flu-like symptoms such as fever, chills, coughing, nausea, chest pain and muscle soreness) as well as irritation of the lungs and nose (Tokar et al., 2013; Canadian Centre for Occupational Health and Safety (CCOHS), 2016).

Iron is classified as a Group 1 carcinogen for lung cancer (IARC, 2012b). Iron ore mining and processing as well as working with molten metals in foundry operations will expose workers to iron fumes and oxides and this exposure may lead to siderosis, metal fume fever or dyspnoea (United States Department of Labor, 1973).

\subsubsection{Lead}

Lead $(\mathrm{Pb})$ may be used as a coating on base metals and may be emitted during gouging and lancing processes on the base metal (Stanton, 2014). Lead is a soft, silvery, bluish white and 
malleable metal and is the metal with the greatest possibility of poisoning workers. Lead is mainly stored in skeletal bones and displaces calcium (Moline and Landrigan, 2005; Firth, 2007). Exposure to lead oxide fumes may cause peripheral neuropathy and haemolytic anaemia and may affect the gastrointestinal, nervous (intellectual development), skeletal, reproductive (sperm abnormalities), blood (increased blood pressure) and immune systems and may lead to chronic nephropathy (kidney disease) (NOHSC, 1990; Moline and Landrigan, 2005; Firth, 2007; Tokar et al., 2013).

Nervous system effects may include lead encephalopathy (damage or malfunction of the brain) and peripheral neuropathy (damage to peripheral nerves) (Tokar et al., 2013). Lead encephalopathy may lead to lethargy (drowsiness/unenergetic), dizziness, reduced level of consciousness, ataxia (lack of muscle coordination), epilepsy, possible blindness, mental retardation, coma and eventually death (Tokar et al., 2013). Segmental demyelination (damage to myelin sheath around nerves) and axonal degradation are characteristics of peripheral neuropathy and this may lead to motor nerve dysfunction (Tokar et al., 2013).

Effects on the reproductive system may include hypermenorrhoea (heavy menstrual flow), polymenorrhoea (frequently occurring menstrual cycle), spontaneous abortion, premature birth and smaller offspring (low birth weight) in women and sperm abnormalities, lower sperm count and motility and impotence in men (Tang and Zhu, 2003; ATSDR, 2010). A causal relationship exists between lead exposure and hypertension (Tokar et al., 2013).

Lead and lead compounds are classified as Group 2A (inorganic lead) and Group 3 (organic lead) human carcinogens and shows an increased risk for cancer of the lung and kidney as well as possible cancer of the stomach, brain and nervous system cancer (IARC, 2006b). Smelter operators and construction workers are probably the largest group of people occupationally exposed to lead fumes and this exposure may lead to kidney diseases, anaemia, neurological and gastrointestinal effects as well as lung cancer (United States Department of Labor, 2015).

\subsubsection{Manganese}

Manganese $(\mathrm{Mn})$ could be present in the fumes emitted from the gouging and lancing processes as it is present in the base metals that are worked on (Cary, 1989; Total Materia, 2001). Manganese is an essential element, is the second most abundant heavy metal in the earth's crust and may exist in six valence states (Franzblau and Fromes, 2005; Tokar et al., 2013; Hanley et al., 2015). Manganese is used in steel production and welding rods and welders are possibly the largest group of people occupationally exposed to manganese and 
are most likely to develop neurological effects, chronic bronchitis and metal fume fever (Hanley et al., 2015; Tian et al., 2016). Manganese fumes may lead to irritation of the respiratory tract, acute inflammation in the lungs, asthma, bronchitis, pneumonitis and may cause a decrease in lung function (Franzblau and Fromes, 2005; Firth, 2007; Tokar et al., 2013; Hanley et al., 2015). When inhaled, manganese particles can penetrate to the deepest structures of the lungs and can also be absorbed into the bloodstream. While travelling in the bloodstream, manganese particles can reach the blood-brain barrier and some of these particles may penetrate the blood-brain barrier and accumulate in the basal ganglia in the brain.

Manganese particles may cause neurotoxic effects from the basal ganglia (Tian et al., 2016). The inhalation of manganese fumes may lead to the development of a neurological disorder similar to Parkinson's disease, known as manganism (Franzblau and Fromes, 2005; Sriram et al., 2015). It affects dopamine release from dopaminergic neurons and may cause bradykinesia (slow movements), rigidity, behavioural changes, emotional instability, memory loss, speech disturbances, dystonia (involuntary muscle spasms), muscle cramps and a decrease in muscle movement (Antonini et al., 2006; Tokar et al., 2013). Manganese does not have a cancer classification; however, this does not mean that it does not cause cancer. The carcinogenicity of manganese is still unknown due to lack of information available. (ATSDR, 2011b).

\subsubsection{Mercury}

Mercury $(\mathrm{Hg})$ is a naturally occurring metal in the crust of the earth and is released through mining and may be present in the product being mined. The instruments that crush this product may contain trace amounts of mercury that may be emitted during gouging and lancing processes on these instruments (WHO, 2016). Mercury is a toxic metal and is more hazardous in the form of a vapour than in liquid form (Tokar et al., 2013). Exposure to mercury vapours or fumes may lead to interstitial pneumonitis, corrosive bronchitis, kidney damage and it may be associated with effects on the central nervous system such as increased excitability, the development of tremors, tachycardia (abnormally fast heart rate), memory loss, headaches, depression, neuromuscular effects, insomnia and motor and cognitive dysfunction (Tokar et al., 2013; WHO, 2016). Methyl mercury compounds are classified as Group 2B human carcinogens; whereas metallic mercury and inorganic mercury are classified as Group 3 human carcinogens (IARC, 1993). Workers in ore mining are possibly the largest group of people occupationally exposed to mercury fumes and these people will likely develop permanent kidney and nervous system impairment (United States Department of Labor, 2015). 


\subsubsection{Nickel}

Nickel $(\mathrm{Ni})$ is present in base metals and could be emitted as a fume during gouging and lancing processes (Cary, 1989; Total Materia, 2001; Stanton, 2014). Nickel is an abundant trace element, with various industrial uses including production of stainless steel (Franzblau and Garabrant, 2005b; Sivulka, 2005; IARC, 2012a). Metallic nickel, nickel fumes, nickel compounds and nickel oxides can cause contact dermatitis, sensitisation, irritation to mucous membranes, lung irritation, pneumonia (lung inflammation), occupational asthma, pulmonary fibrosis, pneumoconiosis and respiratory failure (Franzblau and Garabrant, 2005b; Kang et al., 2011; Schaumlöffel, 2012; Tokar et al., 2013).

Metallic nickel is a possible human carcinogen (Group 2B) and may cause respiratory as well as nasal cancer (Franzblau and Garabrant, 2005b; IARC, 2012a; Keane, 2014). Nickel compounds are classified as human carcinogens (Group 1) for cancer of the nasal cavity, paranasal sinuses and lungs (Franzblau and Garabrant, 2005b; IARC, 2012a). People working in the nickel production and processing industries, manufacturing of stainless steel industries, electroplating industries as well as welding of alloys and nickel may be categorised under the potentially highest exposed workers. These people are most likely to develop dermatitis, asthma, lung and nasal cancers and inflammation of the lungs (Health and Safety Executive (HSE), 2013; United States Environmental Protection Agency (US EPA), 2016).

\subsubsection{Silver}

Silver $(\mathrm{Ag})$ could be present in the fumes emitted from the gouging and lancing processes as it is present in the base metals that are worked on and it can also be used as a coating on base metals (Meo and Al-Khlaiwi, 2003). Silver is a rare, soft, and 'silver'-coloured metal (Tokar et al., 2013). Exposure to silver dusts or fumes may lead to the development of lung and throat irritation, breathing problems, lesions on the kidneys and lungs, chronic bronchitis, asthma, emphysema, decrease in pulmonary volume, chronic alveolar inflammation, decrease in blood pressure, changes in blood cells and arteriosclerosis (Drake and Hazelwood, 2005; Ahamed et al., 2010; Quadros and Marr, 2010; Tokar et al., 2013; ATSDR, 2015a). Prolonged exposure to silver fumes or vapours may lead to the development of argyria (pigmentation of the skin) and/or argyrosis (pigmentation of the eyes) which leads to some areas of the skin and other tissues turning ash-grey or bluish-grey (Drake and Hazelwood, 2005; Tokar et al., 2013; ATSDR, 2015a). Internal organs, the eyes and areas of the body exposed to the sun (hands, nails, forearms, face and ears) are more likely to become pigmented and to turn ashgrey or bluish-grey (Drake and Hazelwood, 2005). Solders, welders and silver plating workers may be categorised under the highest exposed workers and may develop argyria and/or 
argyrosis, asthma and chronic bronchitis (Johnson, 2015). Silver does not have a cancer classification (ATSDR, 2011c).

\subsubsection{Tin}

Tin (Sn) may also be used as a coating on base metals and may be emitted during gouging and lancing processes (Stanton, 2014). Tin is a silver-white metal which may lead to eye, skin and respiratory irritation, pulmonary fibrosis, pulmonary changes, interstitial pneumonia, effects in the gastrointestinal system and neurological problems (Cole et al., 1964; Liu et al., 2012; Tokar et al., 2013; ATSDR, 2014). Tin oxide exposure, including stannous oxide (SnO) and stannic oxide $\left(\mathrm{SnO}_{2}\right)$, may lead to the development of a benign non-fibrotic pneumoconiosis, known as stannosis, which is characterised by the accumulation of tin oxide particles in the pulmonary parenchyma (Yilmaz et al., 2009; Liu et al., 2012). Solders and smelting operators are possibly the largest group of people occupationally exposed to tin fumes and oxides and may lead to people working in these occupations to develop stannosis, pulmonary fibrosis and interstitial pneumonia (Toxicology Data Network, 2001; Tokar et al., 2013). Tin does not have a cancer classification (ATSDR, 2011d).

\subsubsection{Zinc}

Zinc (Zn) may be used as a metal coating on base metals and may be emitted during gouging and lancing processes (Stanton, 2014). Zinc is an essential nutrient and is found in the environment (Franzblau and Fromes, 2005; Firth, 2007). Exposure to zinc fumes and compounds may have the following health effects: inflammation of lung tissue, lung fibrosis, pneumonitis, occupational asthma, damage to the mucous membranes, bronchial mucosal oedema, interstitial oedema and irritation to the nose, throat and eyes (Franzblau and Fromes, 2005; Firth, 2007; Tokar et al., 2013). Exposure to zinc oxide may also lead to metal fume fever (MFF) within two to ten hours after inhalation thereof. MFF is characterised by flu-like symptoms such as sore throat, cough, fever, chills, sweating, fatigue, chest pain/tightness, dyspnoea, nausea, vomiting, muscle soreness, rigors (shivering), malaise (feeling of illness or discomfort) and also a metallic taste in the mouth (Franzblau and Fromes, 2005; Tokar et al., 2013).

Zinc is not classified as a human carcinogen (ATSDR, 2011e). Welding, electroplating, brass plating and galvanising are occupations that have a tendency to have the highest exposure to zinc fumes and oxides and may cause people working in these occupations to develop asthma, metal fume fever and lung fibrosis (Cooper, 2008; Hartmann et al., 2014). 
The metals in Table 2 may also be present in the metal fumes emitted during gouging and lancing processes; however, the health effects caused by these metals are only summarised in short.

Table 2: Table depicting other metals with their most important ill health effects.

\begin{tabular}{|c|c|c|}
\hline Metal & Health effects & Reference \\
\hline Barium (Ba) & Respiratory effects & Tokar et al., 2013 \\
\hline Calcium (Ca) & Skin and respiratory effects & $\begin{array}{l}\text { Centers for Disease Control } \\
\text { and Prevention (CDC), } \\
2016 a\end{array}$ \\
\hline Copper (Cu) & Respiratory effects & CCOHS, 2016 \\
\hline Magnesium (Mg) & Respiratory effects & Tokar et al., 2013 \\
\hline Molybdenum (Mo) & Respiratory effects & Tokar et al., 2013 \\
\hline Palladium (Pd) & $\begin{array}{l}\text { Eye, skin and respiratory } \\
\text { effects }\end{array}$ & Tokar et al., 2013 \\
\hline Potassium (K) & $\begin{array}{l}\text { Eye, skin and respiratory } \\
\text { effects }\end{array}$ & CDC, 2016b \\
\hline Selenium (Se) & $\begin{array}{l}\text { Cardiovascular and } \\
\text { respiratory effects }\end{array}$ & Tokar et al., 2013 \\
\hline Sodium (Na) & $\begin{array}{l}\text { Eye, skin and respiratory } \\
\text { effects }\end{array}$ & CDC, 2016c \\
\hline Strontium (Sr) & Little or no known effects & ATSDR, 2015b \\
\hline Titanium (Ti) & Respiratory effects & Tokar et al., 2013 \\
\hline Tungsten (W) & Respiratory effects & ATSDR, 2015c \\
\hline Zirconium (Zr) & Skin and respiratory effects & CDC, 2016d \\
\hline
\end{tabular}

In conclusion, gouging and lancing processes may liberate particle size fractions and metals discussed within this literature study with the possibility of exposing workers to a variety of metals of different particle size fractions. 


\subsection{References}

Agency for Toxic Substances and Disease Registry (ATSDR). (2004) Toxic Substances Portal - Cobalt. Available from: URL: http://www.atsdr.cdc.gov/phs/phs.asp?id=371\&tid=64\#bookmark03 (accessed 19 July 2016) Agency for Toxic Substances and Disease Registry (ATSDR). (2010) Lead toxicity. Available from: URL: http://www.atsdr.cdc.gov/csem/csem.asp?csem=7\&po=10 (accessed 18 July 2016)

Agency for Toxic Substances and Disease Registry (ATSDR). (2011a) ToxGuide for Aluminum. Available from: URL: http://www.atsdr.cdc.gov/toxguides/toxguide-22.pdf (accessed 19 July 2016)

Agency for Toxic Substances and Disease Registry (ATSDR). (2011b) Manganese. Available from: URL: http://www.atsdr.cdc.gov/substances/toxsubstance.asp?toxid=23 (accessed 10 May 2016)

Agency for Toxic Substances and Disease Registry (ATSDR). (2011c) Silver. Available from: URL: https://www.atsdr.cdc.gov/substances/toxsubstance.asp?toxid=97 (accessed 10 May 2016)

Agency for Toxic Substances and Disease Registry (ATSDR). (2011d) Tin. Available from: URL: https://www.atsdr.cdc.gov/substances/toxsubstance.asp?toxid=98 (accessed 10 May 2016)

Agency for Toxic Substances and Disease Registry (ATSDR). (2011e) Zinc. Available from: URL: http://www.atsdr.cdc.gov/substances/toxsubstance.asp?toxid=54 (accessed 10 May 2016)

Agency for Toxic Substances and Disease Registry (ATSDR). (2014) Toxic Substances Portal - Tin. Available from: URL: http://www.atsdr.cdc.gov/toxfaqs/tf.asp?id=542\&tid=98\#bookmark05 (accessed 16 June 2016)

Agency for Toxic Substances and Disease Registry (ATSDR). (2015a) Toxic Substances Portal - Silver. Available from: URL: http://www.atsdr.cdc.gov/phs/phs.asp?id=537\&tid=97\#bookmark02 (accessed 16 June 2016) 
Agency for Toxic Substances and Disease Registry (ATSDR). (2015b) Toxic Substances Portal - $\quad$ Strontium. Available from: URL: http://www.atsdr.cdc.gov/phs/phs.asp?id=654\&tid=120 (accessed 16 June 2016)

Agency for Toxic Substances and Disease Registry (ATSDR). (2015c) Toxic Substances Portal - $\quad$ Tungsten. Available from: URL: http://www.atsdr.cdc.gov/phs/phs.asp?id=804\&tid=157\#bookmark05 (accessed 16 June 2016)

Ahamed M, AISalhi M, Siddiqui MKJ. (2010) Silver nanoparticle application and human health. Clin Chim Acta; 411: 1841-1848.

American Lung Association. (2015) Pneumoconiosis. Available from: URL: http://www.lung.org/lung-health-and-diseases/lung-diseaselookup/pneumoconiosis/?referrer=https://www.google.co.za/ (accessed 12 February 2016) American Thoracic Society. (2015) What is chronic obstructive pulmonary disease? Available from: URL: http://www.thoracic.org/copd-guidelines/for-patients/what-is-chronic-obstructivepulmonary-disease-copd.php (accessed 12 February 2016)

Andujar P, Simon-Deckers A, Galateau-Sallé F et al. (2014) Role of metal oxide nanoparticles in histopathological changes observed in the lung of welders. Part Fibre Toxicol; 11: 1-13.

Antonini JM, Santamaria AB, Jenkins NT et al. (2006) Fate of manganese associated with the inhalation of welding fumes: Potential neurological effects. Neurotoxicol; 27: 304-310.

Antonini JM. (2003) Health effects of welding. Crit Rev Toxicol; 33: 61-103.

Atlas Foundry Company. (2010) Understanding cast irons. Available from: URL: http://www.atlasfdry.com/cast-irons.htm (accessed 16 November 2015)

Behera SN, Betha R, Huang X, Balasubramanian R. (2015) Characterization and estimation of human airway deposition of size-resolved particulate-bound trace elements during a recent haze episode in Southeast Asia. Environ Sci Pollut Res; 22: 4265-4280.

Bepko J, Mansalis K. (2016) Common occupational disorders: asthma, copd, dermatitis, and musculoskeletal disorders. Am Fam Physician; 93: 1000-1006.

BGI Inc. (2007) Instructions: GK2.69 Respirable/Thoracic Cyclone. Available from: URL: http://bgi.mesalabs.com/wp-content/uploads/sites/35/2014/10/GK-2.69_Cyclone.pdf (accessed 1 February 2016) 
Blaszczak-Boxe, A. (2015) Facts About Iron. Available from: URL: http://www.livescience.com/29263-iron.html (accessed 10 May 2016)

Brown JS, Gordon T, Price O, Asgharian B. (2013) Thoracic and respirable particle definitions for human health risk assessment. Part Fibre Toxicol; 10: 1-12.

Brown JS, Zeman KL, Bennett WD. (2002) Ultrafine particle deposition and clearance in the healthy and obstructed lung. Am J Resp Crit Care; 166: 1240-1247.

Canadian Centre for Occupational Health and Safety (CCOHS). (2016) Welding - Fumes and Gases.

Available from:

URL:

https://www.ccohs.ca/oshanswers/safety_haz/welding/fumes.html (accessed 10 May 2016)

Cândea VN, lordache CA, Dinu MO, Ploscariu C. (2009) Thermal cutting equipment for construction materials with thermal lancing. B Trans U Braşov; 2: 105-108.

Cary HB. (1989) Modern Welding Technology. New Jersey, USA: Prentice-Hall. p. 267-278. ISBN 0-13-599283-4.

Cena LG, Anthony TR, Peters TM. (2011) A personal nanoparticle respiratory deposition (NRD) sampler. Environ Sci Technol; 45: 6483-6490.

Cena LG, Keane MJ, Chisholm WP et al. (2014) A novel method for assessing respiratory deposition of welding fume nanoparticles. J Occup Environ Hyg; 11: 771-780.

Centers for Disease Control and Prevention (CDC). (2011) Welding fumes. Available from: URL: http://www.cdc.gov/niosh/pel88/welding.html (accessed 15 July 2016)

Centers for Disease Control and Prevention (CDC). (2013) Cobalt. Available from: URL: http://www.cdc.gov/niosh/topics/cobalt/ (accessed 15 July 2016)

Centers for Disease Control and Prevention (CDC). (2016a) Calcium oxide. Available from: URL: http://www.cdc.gov/niosh/npg/npgd0093.html (accessed 7 June 2016)

Centers for Disease Control and Prevention (CDC). (2016b) Potassium hydroxide. Available from: URL: https://www.cdc.gov/niosh/npg/npgd0523.html (accessed 16 June 2016)

Centers for Disease Control and Prevention (CDC). (2016c) Sodium hydroxide. Available from: URL: http://www.cdc.gov/niosh/npg/npgd0565.html (accessed 16 June 2016) 
Centers for Disease Control and Prevention (CDC). (2016d) Zirconium compounds. Available from: URL: http://www.cdc.gov/niosh/npg/npgd0677.html (accessed 16 June 2016)

Chang C, Demokritou P, Shafer M, Christiani D. (2013) Physicochemical and toxicological characteristics of welding fume derived particles generated from real time welding processes. Environ Sci - Proc Imp; 15: 214-224.

Cheng YS, Su WC. (2013) Thoracic fraction of inhaled fiber aerosol. J Occup Environ Hyg; 10: 194-202.

Cherrie JW, Aitken RJ. (1999) Measurement of human exposure to biologically relevant fractions of the total aerosol. Occup Environ Med; 56: 747-752.

Cole CWD, Davies JVSA, Kipling MD, Ritchie GL. (1964) Stannosis is hearth tinners. Br J Ind Med; 21: 235-241.

Cooper RG. (2008) Zinc toxicology following zinc inhalation. Indian J Occup Environ Med; 12 : 10-13.

Cooper RG, Harrison AP. (2009) The exposure to and health effects of antimony. Indian J Occup Environ Med; 13: 3-10.

Costa M. (2003) Potential hazards of hexavalent chromate in our drinking water. Toxicol Appl Pharmacol; 188: 1-5.

Danish Environmental Protection Agency (DEPA). (2008) Nickel sulphate risk assessment. Available from:

URL: http://eng.mst.dk/media/mst/67158/NickelBackground_EU_RAR_HH_March_2008_final_dra ft.pdf (accessed 1 February 2016)

Donaldson K, Tran L, Jimenez LA et al. (2005) Combustion-derived nanoparticles: A review of their toxicology following inhalation exposure. Part Fibre Toxicol; 2: 1-14.

Drake PL, Hazelwood KJ. (2005) Exposure-related health effects of silver and silver compounds: A review. Ann Occup Hyg; 49: 575-585.

Eschenbacher WL, Kullman GJ, Gomberg CC. (2000) Pulmonary effects of inhaled mineral dusts. in harris rl, editor. patty's industrial hygiene. United States of America: John Wiley \& Sons, Inc. p. 89-130. ISBN 0-471-29756-9. 
Fethke NB, Peters TM, Leonard S et al. (2015) Reduction of biomechanical and welding fume exposures in stud welding. Ann Occup Hyg; 60:387-401.

Firth I. (2007) Metals in the workplace. In Tillman C, editor. Principles of Occupational Health \& Hygiene: An Introduction. Singapore: ANL Printers. p. 173-208. ISBN 9781741750584.

Franzblau A, Fromes, MC. (2005) Copper, Manganese, Thallium, Vanadium, Zinc. In Rosenstock L, Cullen MR, Brodkin CA, Redlich CA, editors. Textbook of Clinical Occupational and Environmental Medicine. China: Elsevier Inc. p. 983-990. ISBN 0721689744.

Franzblau A, Garabrant DH. (2005a) Chromium. In Rosenstock L, Cullen MR, Brodkin CA, Redlich CA, editors. Textbook of Clinical Occupational and Environmental Medicine. China: Elsevier Inc. p. 958-960. ISBN 0721689744.

Franzblau A, Garabrant DH. (2005b) Nickel. In Rosenstock L, Cullen MR, Brodkin CA, Redlich CA, editors. Textbook of Clinical Occupational and Environmental Medicine. China: Elsevier Inc. p. 961-963. ISBN 0721689744.

Giorio C, Tapparo A, Scapellato ML et al. (2013) Filed comparison of a personal cascade impactor sampler, an optical particle counter and CEN-EU standard methods for $\mathrm{PM}_{10}, \mathrm{PM}_{2,5}$, and $\mathrm{PM}_{1}$ measurement in urban environment. J Aerosol Sci; 65: 111-120.

Hanley KW, Andrews R, Bertke S, Ashley K. (2015) Manganese fractionation using a sequential extraction method to evaluate welders' shielded metal arc welding exposures during construction projects in oil refineries. J Occup Environ Hyg; 12: 774-784.

Hariri A, Azreen N, Abdull N et al. (2014) Determination of customer requirement for welding fumes index development in automotive industries by using quality function deployment approach. Int J Automot Mech Eng; 9: 1609-1619.

Hartmann L, Bauer M, Bertram J et al. (2014) Assessment of the biological effects of welding fumes emitted from metal inert gas welding processes of aluminium and zinc-plated materials in humans. Int J Hyg Environ Health; 217: 160-168. 
Health and Safety Executive (HSE). (2010) Guidelines for work with irritants, sensitisers and other skin damaging agents. Available from: URL: https://www.google.co.za/url?sa=t\&rct=j\&q=\&esrc=s\&source=web\&cd=8\&cad=rja\&uact=8\&v ed=0ahUKEwiO24XWp6HLAhWGORQKHdOLD38QFghJMAc\&url=https\%3A\%2F\%2Fwww. qub.ac.uk\%2Fdirectorates\%2FHumanResources\%2FOccupationalHealthandSafety\%2FFile Store\%2FWordDocuments\%2FFiletoupload\%2C369623\%2Cen.doc\&usg=AFQjCNExNs9TT OvUjJ0BxbVVOXAs1q6DnA\&sig2=4X-qMI48UIGqaXEh5TySLg (accessed 2 March 2016)

Health and Safety Executive (HSE). (2013) Nickel and you. Available from: URL: http://www.hse.gov.uk/pubns/indg351.pdf (accessed 19 July 2016)

IARC (International Agency for Research on Cancer). (1989) Monographs on the evaluation of carcinogenic risks to humans (Volume 47): Some organic solvents, resin monomers and related compounds, pigments and occupational exposures in paint manufacture and painting. Available from: URL: http://monographs.iarc.fr/ENG/Monographs/vol47/mono47.pdf (accessed 16 June 2016)

IARC (International Agency for Research on Cancer). (1991) Monographs on the evaluation of carcinogenic risks to humans (Volume 52): Chlorinated drinking-water; chlorination byproducts; some other halogenated compounds; cobalt and cobalt compounds. Available from: URL: http://monographs.iarc.fr/ENG/Monographs/vol52/mono52.pdf (accessed 10 May 2015)

IARC (International Agency for Research on Cancer). (1993) Monographs on the evaluation of carcinogenic risks to humans (Volume 58): Beryllium, cadmium, mercury and exposures in the glass manufacturing industry. Available from: URL: https://monographs.iarc.fr/ENG/Monographs/vol58/mono58.pdf (accessed 16 June 2016)

IARC (International Agency for Research on Cancer). (2006a) Monographs on the evaluation of carcinogenic risks to humans (Volume 86): Cobalt in Hard Metals and Cobalt Sulfate, Gallium Arsenide, Indium Phosphide and Vanadium Pentoxide. Available from: URL: http://monographs.iarc.fr/ENG/Monographs/vol86/mono86.pdf (accessed 10 May 2015)

IARC (International Agency for Research on Cancer). (2006b) Monographs on the evaluation of carcinogenic risks to humans (Volume 87): Inorganic and Organic Lead Compounds. Available from: URL: http://monographs.iarc.fr/ENG/Monographs/vol87/mono87.pdf (accessed 10 May 2015) 
IARC (International Agency for Research on Cancer). (2012a) Monographs on the evaluation of carcinogenic risks to humans (Volume 100C): Arsenic, metals, fibres, and dusts. Available from: URL: http://monographs.iarc.fr/ENG/Monographs/vol100C/mono100C.pdf (accessed 10 May 2015)

IARC (International Agency for Research on Cancer). (2012b) Monographs on the evaluation of carcinogenic risks to humans (Volume 100F): Chemical agents and related occupations. Available from: URL: http://monographs.iarc.fr/ENG/Monographs/vol100F/mono100F.pdf (accessed 10 May 2015)

IARC (International Agency for Research on Cancer). (2016) Agents classified by the IARC Monographs, volumes 1-115. Available from: URL: http://monographs.iarc.fr/ENG/Classification/ (accessed 10 May 2015)

lavicoli I, Leso V, Fontana L et al. (2013) Characterization of inhalable, thoracic, and respirable fractions and ultrafine exposure during grinding, brazing, and welding activities in a mechanical engineering factory. Int J Occup Env Med; 55: 430-445.

Jiménez AS, Van Tongeren M, Cherrie JW. (2011) A review of monitoring methods for inhalable hardwood dust. Available from: URL: https://www.google.co.uk/url?sa=i\&rct=j\&q=\&esrc=s\&source=images\&cd=\&cad=rja\&uact=8 \&ved=0CAUQjRxqFQoTClfogOGNI8kCFUQ8FAodZukKkA\&url=http\%3A\%2F\%2Fec.europa .eu\%2Fsocial\%2FBlobServlet\%3Fdocld\%3D10153\%26langld\%3Den\&psig=AFQjCNEJ6F8T opGHjBRCPKppeEDnVaGvPw\&ust=1447837345411503 (accessed 17 November 2015)

Johnson GT. (2015) Silver. In Harbison RD, Bourgeois MM, Johnson GT, editors. Hamilton and Hardy's Industrial Toxicology. USA: John Wiley \& Sons. p. 229-232. ISBN 9781118834213.

Jumpponen M, Rönkkömäki H, Pasanen P, Laitinen J. (2014) Occupational exposure to solid chemical agents in biomass-fired power plants and associated health effects. Chemosphere; 104: 25-31.

Kang GS, Gillespie PA, Gunnison A et al. (2011) Long-term inhalation exposure to nickel nanoparticles exacerbated atherosclerosis in a susceptible mouse model. Environ Health Persp; 119: 176-181.

Keane MJ. (2014) An evaluation of welding processes to reduce hexavalent chromium exposures and reduce costs by using better welding techniques. Environ Health Insights; 8: 47-50. 
Kelly RJ. (2002) Particulates. In Plog BA, Quinlan PJ, editors. Fundamentals of Industrial Hygiene. United States of America: National Safety Council. p. 169-206. ISBN 0-87912-2161.

Kenny LC, Aitken RJ, Baldwin PEJ et al. (1999) The sampling efficiency of personal inhalable aerosol samplers in low air movement environments. J Aerosol Sci; 30: 627-638.

Kim CS, Hu SC. (2006) Total respiratory tract deposition of fine micrometer-sized particles in healthy adults: empirical equations for sex and breathing pattern. J Appl Physiol; 101: 401 412.

Klasson M, Bryngelsson IL, Pettersson C et al. (2016) Occupational exposure to cobalt and tungsten in swedish hard metal industry: air concentrations of particle mass, number, and surface area. Ann Occup Hyg; 60: 684-699.

Koch W, Dunkhorst W, Lödding $\mathrm{H}$ et al. (2002) Evaluation of the respicon as a personal inhalable sampler in industrial environments. J Environ Monit; 4: 657-662.

Kock H, Civic T, Koch W. (2015) Beryllium Concentrations at European Workplaces: Comparison of 'Total' and Inhalable Particulate Measurements. Ann Occup Hyg; 59: 788-796.

Kreiss K. (2005) Beryllium and Cobalt. In Rosenstock L, Cullen MR, Brodkin CA, Redlich CA, editors. Textbook of Clinical Occupational and Environmental Medicine. China: Elsevier Inc. p. 950-9954. ISBN 0721689744.

Krug HF, Wick P. (2011) Nanotoxicology: an interdisciplinary challenge. Angew Chem Int Ed; 50:1260-1278.

Kuempel ED, O'Flaherty EJ, Stayner LT et al. (2001) A biomathematical model of particle clearance and retention in the lungs of coal miners. Regul Toxicol Pharm; 34: 69-87.

La Vecchia GM, Maestrelli P. (2011) New welding processes and health effects of welding (Italian). G Ital Med Lav Ergon; 33: 252-256.

Lee MH, McClellan WJ, Candela J et al. (2007) Reduction of nanoparticle exposure to welding aerosols by modification of the ventilation system in the workplace. J Nanopart Res; 9: 127136.

Lehman-McKeeman LD. (2013) Absorption, distribution and excretion of toxicants. In Klaassen CD, editor. Casarett \& Doull's Toxicology: The Basic Science of Poison. China: McGraw-Hill. p. 153-183. ISBN 978-0-07-176923-5. 
Leikauf GD. (2013) Toxic responses of the respiratory system. In Klaassen CD, editor. Casarett \& Doull's Toxicology: The Basic Science of Poison. China: McGraw-Hill. p. 717. ISBN 978-0-07-176923-5.

Lever MJ, Schroter RC. (1995) Deposition of inhaled materials in the respiratory tract. In Harrington JM, Gardiner K, editors. Occupational Hygiene. Oxford: Blackwell Science Ltd. p. 23-34. ISBN 0-632-03734-2.

Li SN, Lundgren DA, Rovel-Rixx D. (2000) Evaluation of six inhalable aerosol samplers. Am Ind Hyg Assoc J; 61: 506-516.

Lippmann M. (1999) Rationale for particle size-selective aerosol sampling. In Vincent JH, editor. Particle size-selective sampling of particulate air contaminants. Cincinnati, $\mathrm{OH}$ : American Conference of Governmental Industrial Hygienists (ACGIH). p. 3-27. ISBN 9781882417308.

Liu HH, Chen CY, Chen Gl et al. (2012) Relationship between indium exposure and oxidative damage in workers in indium tin oxide production plants. Int Arch Occup Environ Health; 85: 447-453.

Lynch JR. (2000) Theory and rationale of exposure measurement. In Harris RL, editor. Patty's Industrial Hygiene. United States of America: John Wiley \& Sons, Inc. p. 211-264. ISBN 0471-29756-9.

Lyndon GS, Platcow PA. (2011) Welding and thermal cutting. Available from: URL: http://www.ilo.org/iloenc/part-xiii/metal-processing-and-metal-working-industry/metalprocessing-and-metal-working/item/676-welding-and-thermal-cutting (accessed 6 July 2015) Martin AR, Finlay WH. (2006) A general, algebraic equation for predicting total respiratory tract deposition of micrometer-sized aerosol particles in humans. Aerosol Sci; 38: 246-253.

Maynard AD, Kuempel ED. (2005) Airborne nanostructured particles and occupational health. J Nanopart Res; 7: 587-614.

McClellan RO. (2002) Setting ambient air quality standards for particulate matter. Toxicology; 181-182: 329-347.

Méndez LB, Gookin G, Phalen RF. (2010) Inhaled aerosol particle dosimetry in mice: A review. Inhal Toxicol; 22: 1032-1037.

Meo SA, Al-Khlaiwi T. (2003) Health hazards of welding fumes. Saudi Med J; 24: 1176-1182. 
Mohan S, Sivapirakasam SP, Bineesh P, Satpathy KK. (2014) Strategies for controlling welding fumes at the source - A review. Appl Mech Mater; 592-594: 2539-2545.

Moline JM, Landrigan PJ. (2005) Lead. In Rosenstock L, Cullen MR, Brodkin CA, Redlich CA, editors. Textbook of Clinical Occupational and Environmental Medicine. China: Elsevier Inc. p. 967-978. ISBN 0721689744.

Moroni B, Viti C. (2009) Grain size, chemistry, and structure of fine and ultrafine particles in stainless steel welding fumes. Aerosol Sci; 40: 938-949.

Muñoz-Escalona P, Payares MC, Dorta M, Diaz R. (2006) Analysis and influence of acetylene and propane during oxyfuel gas cutting of 1045 carbon steel. J Mater Eng Perform; 15: 684692.

National Occupational Health and Safety Commission (NOHSC). (1990) Welding: fumes and gases. Australia: Ambassador Press. ISBN 0-644-12857-7.

Nazaroff WW. (2004) Indoor particle dynamics. Indoor Air; 14: 175-183.

Nilsson PT, Isaxon C, Eriksson AC et al. (2013) Nano-objects emitted during maintenance of common particle generators: direct chemical characterization with aerosol mass spectrometry and implications for risk assessments. J Nanopart Res; 15: 1-16.

Notø HP, Nordby KC, Eduard W. (2016) Relationships between personal measurements of 'total' dust, respirable, thoracic, and inhalable aerosol fractions in the cement production industry. Ann Occup Hyg; 60: 453-466.

Oberdörster G, Kane AB, Klaper RD, Hurt RH. (2013) Nanotoxicology. In Klaassen CD, editor. Casarett \& Doull's Toxicology: The Basic Science of Poison. China: McGraw-Hill. p. 11891229. ISBN 978-0-07-176923-5.

Oberdörster G, Oberdörster E, Oberdörster J. (2005) Nanotoxicology: an emerging discipline evolving from studies of ultrafine particles. Environ Health Persp; 113: 823-839.

Persoons R, Arnoux D, Monssu T et al. (2014) Determinants of occupational exposure to metals by gas metal arc welding and risk management measures: A bio monitoring study. Toxicol Lett; 231: 135-141.

Petavratzi E, Kingman S, Lowndes I. (2005) Particulates from Mining Operations: A review of sources, effects and regulations. Miner Environ; 18: 1183-1199. 
Pickford G, Davies B. (2007) Aerosols. In Tillman C, editor. Principles of Occupational Health \& Hygiene: An Introduction. Singapore: ANL Printers. p. 125-171. ISBN 9781741750584.

Plog BA. (2002) Overview of Industrial Hygiene. In Plog BA, Quinlan PJ, editors. Fundamentals of Industrial Hygiene. United States of America: National Safety Council. p. 332. ISBN 0-87912-216-1.

Pui DYH, Qi C, Stanley N et al. (2008) Recirculating air filtration significantly reduces exposure to airborne nanoparticles. Environ Health Perspect; 116: 863-866.

Quadros ME, Marr LC. (2010) Environmental and human health risks of aerosolized silver nanoparticles. J Air Waste Manag Assoc; 60: 770-781.

Reist PC. (2000) Basic aerosol science. In Harris RL, editor. Patty's Industrial Hygiene. United States of America: John Wiley \& Sons, Inc. p. 355-410. ISBN 0-471-29756-9.

Riihimäki V, Aitio A. (2012) Occupational exposure to aluminium and its biomonitoring in perspective. Crit Rev Toxicol; 42: 827-853.

Riley MR, Boesewetter DE, Kim AM, Sirvent FP. (2003) Effects of metals Cu, Fe, Ni, V, and Zn on rat lung epithelial cells. Toxicology; 190: 171-184.

Royal Society of Chemistry. (2016a) Antimony. Available from: URL: http://www.rsc.org/periodic-table/element/51/antimony (accessed 7 June 2016)

Royal Society of Chemistry. (2016b) Iron. Available from: URL: http://www.rsc.org/periodictable/element/26/iron (accessed 10 May 2016)

Sasse FH, Frohlich RL, Green RD et al. (1978) Arc and Oxygen Cutting. In Kearns WH, editor. Welding Handbook Volume 2: Welding Processes - Arc and Gas Welding and Cutting, Brazing, and Soldering. Miami, FL: American Welding Society. p. 459-516. ISBN 0-87171148-6.

Schaumlöffel D. (2012) Nickel species: Analysis and toxic effects. J Trace Elem Med Biol; 26: $1-6$.

Schröder HHE. (2014) Dusts, solvents and metals. In Schoeman JJ, Van Den Heever, editors. Occupational Hygiene: The Science. South Africa: SUN MeDIA. p. 229-264. ISBN 978-0-62063414-4. 
Schulte P, Geraci C, Zumwalde R et al. (2008) Occupational risk management of engineered nanoparticles. J Occup Environ Hyg; 5: 239-249.

Shaffer RE, Rengasamy S. (2009) Respiratory protection against airborne nanoparticles: a review. J Nanopart Res; 11: 1661-1672.

Sivulka DJ. (2005) Assessment of respiratory carcinogenicity associated with exposure to metallic nickel: A review. Regul Toxicol Pharm; 43: 117-133.

Skaugset NP, Ellingsen DG, Notø H et al. (2013) Intersampler field comparison of Respicon (R), IOM, and closed-face $25 \mathrm{~mm}$ personal aerosol samplers during primary production of aluminium. Ann Occup Hyg; 57(8): 1054-1064.

SKC Inc. (2013) Sampling Train - Filters and Cyclones. Available from: URL: http://www.skcinc.com/catalog/pdf/instructions/1166.pdf (accessed 12 May 2015)

SKC Inc. (2014) SKC Reusable Parallel Particle Impactors (PPI) - Operating Instructions. Available from: URL: http://www.skcinc.com/catalog/pdf/instructions/38038.pdf (accessed 1 February 2016)

Sleeth DK. (2013) The impact of particle size selective sampling methods on occupational assessment of airborne beryllium particulates. Environ Sci - Proc Imp; 15: 898-903.

Sriram K, Lin GX, Jefferson AM et al. (2015) Modifying welding process parameters can reduce the neurotoxic potential of manganese-containing welding fumes. Toxicology; 328 : 168-178.

Stacey P, Lee T, Thorpe A et al. (2014) Collection efficiencies of high flow rate personal respirable samplers when measuring arizona road dust and analysis of quartz by $\mathrm{x}$-ray diffraction. Ann Occup Hyg; 58: 512-523.

Stanton DW. (2014) Welding Fumes. In Schoemann JJ, Van den Heever DJ, editors. Occupational Hygiene: The Science, Volume 1. Bloemfontein: SUN MeDIA. p. 265-309. ISBN 978-0-620-63414-4.

Sundar S, Chakravarty J. (2010) Antimony toxicity. Int J Environ Res Public Health; 7: 42674277.

Sung JC, Pulliam BL, Edwards DA. (2007) Nanoparticles for drug delivery to the lungs. Biotechnology; 25: 563-570. 
Taiwo OA. (2005) Aluminium. In Rosenstock L, Cullen MR, Brodkin CA, Redlich CA, editors. Textbook of Clinical Occupational and Environmental Medicine. China: Elsevier Inc. p. 943945. ISBN 0721689744.

Tang N, Zhu ZQ. (2003) Adverse reproductive effects in female workers of lead battery plants. Int J Occup Med Environ Health; 16: 359-361.

Tashiro S, Zeniya T, Yamamoto $\mathrm{K}$ et al. (2015) Numerical analysis of fume formation mechanism in TIG welding. Weld Int; 29: 165-172.

Thomas RJ, Webber D, Sellors W et al. (2008) Characterization and deposition of respirable large- and small-particle bioaerosols. Appl Environ Microbiol; 74: 6437-6443.

Thomas, GP. (2013) Air carbon arc cutting: fundamentals, industrial applications and benefits. Available from: URL: http://www.azom.com/article.aspx?ArticleID=7905 (accessed 25 January 2016)

Tian L, Inthavong K, Lidén G et al. (2016) Transport and deposition of welding fume agglomerates in a realistic human nasal airway. Ann Occup Hyg; 60: 731-747.

Tokar EJ, Boyd WA, Freedman JH, Waalkes MP. (2013) Toxic effects of metals. In Klaassen CD, editor. Casarett \& Doull's Toxicology: The Basic Science of Poison. China: McGraw-Hill. p. 981-1030. ISBN 978-0-07-176923-5.

Total Materia. (2001) Classification of carbon and low-allow steels. Available from: URL: http://www.totalmateria.com/articles/Art62.htm (accessed 16 November 2015)

Toxicology Data Network. (2001) Tin Oxide. Available from: URL: https://toxnet.nlm.nih.gov/cgi-bin/sis/search/a?dbs+hsdb:@term+@DOCNO+5064 (accessed 19 July 2016)

Trakumas S, Salter E. (2009) Parallel particle impactor - novel size-selective particle sampler for accurate fractioning of inhalable particles. J Phys; 151: 1-16.

TSI Inc. (2015) Respicon particle sampler 8522. Available from: URL: http://www.tsi.com/respicon-particle-sampler-8522/ (accessed 1 February 2016)

United States Department of Labor. (1973) Occupational Health Guideline for Iron Oxide Fume. Available from: URL: http://www.cdc.gov/niosh/docs/81-123/pdfs/0344.pdf (accessed 19 July 2016) 
United States Department of Labor. (2015) Toxic Metals. Available from: URL: https://www.osha.gov/SLTC/metalsheavy/ (accessed 19 July 2016)

United States Environmental Protection Agency (US EPA). (2016) Nickel Compounds. Available from: URL: https://www3.epa.gov/airtoxics/hlthef/nickel.html (accessed 19 July 2016)

Vincent JH. (2007) Aerosol sampling: Science, standards, instrumentation and applications. Chichester, UK: John Wiley \& Sons Ltd. p 222-470. ISBN 978-0-470-02725-7.

Wang H, Pranda P, Hlavacek V. (2004) The eutectic generation effect and chemical modification of thermal lance cutting of concrete. J Mater Sci; 39: 7003-7008.

Widmaier EP, Raff H, Strang KT. (2008) Vander's Human Physiology: The Mechanisms of Body Function. New York, USA: McGraw-Hill. p. 475-476, 724. ISBN 978-0-07-128366-3.

Wilson WE, Chow JC, Claiborn C et al. (2002) Monitoring of particulate matter outdoors. Chemosphere; 49: 1009-1043.

Win-Shwe TT, Fujimaki H. (2011) Nanoparticles and Neurotoxicity. Int J Mol Sci; 12: 62676280.

Wittczak T, Walusiak J, Palczyński C. (2009) Welding-related respiratory diseases. Med Pr; 60: 201-208.

World Health Organization (WHO). (2010) Exposure to Arsenic: A major public health concern. Available from: URL: http://www.who.int/ipcs/features/arsenic.pdf (accessed19 July 2016)

World Health Organization (WHO). (2012) Arsenic. Available from: URL: http://www.who.int/mediacentre/factsheets/fs372/en/ (accessed 7 June 2016)

World Health Organization (WHO). (2016) Mercury and health. Available from: URL: http://www.who.int/mediacentre/factsheets/fs361/en/ (accessed 19 July 2016)

Yang W, Peters JI, Williams RO. (2008) Inhaled nanoparticles - A current review. Int J Pharm; 356: 239-247.

Yilmaz A, Goçmen Ocal S, Doruk S, Acu B. (2009) Is tin fume exposure benign or not? Two case reports. Tuberk Toraks; 57: 422-426. 
Yu CH, Huang L, Shin JY et al. (2014) Characterization of concentration, particle size distribution, and contributing factors to ambient hexavalent chromium in an area with multiple emission sources. Atmos Environ; 94: 701-708.

Zeidler-Erdely PC, Erdely A, Antonini JM. (2012) Immunotoxicology of arc welding fume: Employee and experimental animal studies. J Immunotoxicol; 9: 411-425. 


\section{CHAPTER 3: ARTICLE}

Annals of Occupational Hygiene publishes original research and development material that helps reduce risk of ill-health resulting from work. The author's instructions are as follows:

\section{Structure}

Papers should generally conform to the pattern: Introduction, Methods, Results, Discussion and Conclusions - consult a recent issue for style of headings. A paper must be prefaced by an abstract of the argument and findings, which may be arranged under the headings Objectives, Methods, Results and Conclusions. Keywords should be given after the list of authors.

\section{Units and symbols}

SI units must be used, though their equivalent in other systems may be given as well.

\section{Figures}

Good quality low resolution electronic copies of figures, which include photographs, diagrams and charts, should be sent with the first submission. It is helpful to reviewers to incorporate them in the word-processor text or at the end. After review, the revised version of the paper should be accompanied by high-resolution electronic copies in a form and of a quality suitable for reproduction. They should be about the size they are to be reproduced, with a font size at least 6 point, using the standard Adobe set of fonts.

\section{Tables}

Tables should be numbered consecutively and given a suitable caption and each table typed on a separate page. Footnotes to tables should be provided below the table and should be referred to by superscript lowercase letters.

\section{References}

References should only be included which are essential to the development of an argument or hypothesis, or which describe methods for which the original account is too long to be reproduced. Only publications which can be obtained by the reader should be referenced. At the end of the paper, references should be listed in alphabetical order by name of first author, using the Vancouver Style of abbreviation and punctuation. ISBNs should be given for books and other publications where appropriate. Internet material can be referred to if it is likely to 
be permanently available and the date on which it was last accessed should be given. References will not be checked editorially, and their accuracy is the responsibility of authors. References in the text should be in the form Jones (1995), or Jones and Brown (1995), or Jones et al. (1995) if there are more than two authors.

Examples:

Reference to a journal publication: Simpson AT, Groves JA, Unwin J, Pinay M. (2000) Mineral oil metal working fluids (MWFs) - Development of practical criteria for mist sampling. Ann Occup Hyg; 44: 165-72.

Reference to a book: Vincent JH. (1989) Aerosol sampling: science and practice. Chichester, UK: John Wiley. ISBN 0471921750.

Reference to a chapter in an edited book: Swift DL, Cheng Y-S, Su Y-F, Yeh H-C. (1994) Ultrafine aerosol deposition in the human nasal and oral passages. In Dodgson J, McCallum RI, editors. Inhaled Particles VII. Oxford: Elsevier Science. p. 77-81. ISBN 0080408419 H.

Reference to an Internet source: Morse SS. (1995) Factors in the emergence of infectious diseases. Emerg Infect Dis [serial online] 1995 Jan-Mar; 1(1). Available from: URL: http://www.cdc.gov/ncidod/EID/eid.htm (accessed 25 Oct 2010)

\section{Ethics}

Authors must produce original data for inspection, if requested by the editor. Possible fraud may be referred to the authors' institutions. 


\title{
Particle size and metal composition of gouging and lancing fumes
}

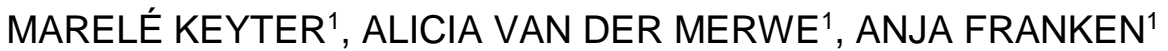

${ }^{1}$ Occupational Hygiene and Health Research Initiative (OHHRI), Faculty of Health Sciences, North-West University, Potchefstroom Campus, Private Bag X6001, Potchefstroom 2520, South Africa.

\section{Corresponding Author}

Ms A van der Merwe

Occupational Hygiene and Health Research Initiative (OHHRI)

Faculty of Health Sciences, North-West University, Potchefstroom Campus

Private Bag X6001

Potchefstroom

2520

South Africa

Tel: 0182991984

Fax: 0182991053

Email: alicia.vandermerwe@nwu.ac.za

Word count: 4888

Keywords: nanoparticles; particle size fractions; mining maintenance work; base metal. 


\subsection{Abstract}

Gouging and lancing processes during mining maintenance operations liberate fumes of unknown particle sizes and metal composition. These fumes are formed when vaporised materials condense in cool air. These processes give rise to very fine solid particles of sizes usually smaller than $1 \mu \mathrm{m}$ in diameter, which will generally agglomerate to form bigger clusters of particles. Inhalation of such a "metal fume mixture" may lead to adverse health effects such as asthma, bronchitis and neurological dysfunction.

Objectives: A field study was conducted to determine the particle size fractions as well as metal composition of fumes emitted during gouging and lancing processes. This study aimed to improve occupational hygiene work practices of workers utilising gouging and lancing methods by sampling different particle size fractions and analysing the metal composition. The study also aimed to include metal fumes and particle fractions not previously included (such as nanoparticles) during respiratory sampling.

Methods: Randomised side-by-side area samples of metalwork fumes liberated during gouging and lancing cutting processes were collected. These processes form part of maintenance work and was conducted in three different workshops at a mine in South Africa. Samplers included the IOM sampler (inhalable fraction), a GK2.69 cyclone (thoracic fraction), an aluminium cyclone (respirable fraction), a NRD sampler (nano-size fraction) and an openface filter cassette (particle size distribution).

Results: Particles in all fractions were present in the metal fumes emitted during gouging and lancing processes. Ambient workplace concentrations of the nano-sized fraction indicated a range of $1.01-3.40 \mathrm{mg} / \mathrm{m}^{3}$ in all three of the workshops. A total of 26 metals were present in the various particle size fractions and included arsenic, chromium, cobalt, lead, manganese, mercury and nickel. Lead was mostly found during lancing and manganese and nickel was found in both gouging and lancing in all four of the fractions. Lancing processes $(\bar{x}=32.3 \mathrm{~nm})$ emit smaller mean particle sizes than gouging processes $(\bar{x}=171.8 \mathrm{~nm})$. No statistically significant differences were found between the three workshops with regard to particle size fractions. Statistical differences were observed for copper, iron, molybdenum and nickel between gouging and lancing processes, with copper, iron and nickel emission higher during gouging processes and molybdenum emission higher during lancing processes.

Conclusions: Particle size fractions within the inhalable, thoracic, respirable as well as nanosize fractions were present in the metal fumes. Lancing could be considered as more hazardous than gouging, since the mean particle size liberated during lancing was smaller 
than the mean particle size liberated during gouging, with regard to nanoparticles. It is possible that adverse health effects may be caused outside of the respiratory system through absorption of nanoparticles into the blood circulation. This indicates the necessity to include the nano-size fraction during future personal exposure assessments and to implement specific control measures to reduce exposure of workers to nanoparticles.

\subsection{Introduction}

There are more than two million people employed on a full-time basis in welding processes and other associated activities worldwide (Sriram et al., 2012; Zeidler-Erdely et al., 2012; Bureau of Labour Statistics, U.S. Department of Labour, 2014; Sriram et al., 2015). These workers are a heterogeneous population utilising different methods and techniques which may influence their occupational exposure, during such processes. While there are various hazards associated with welding processes exposure to fumes emitted during such activities is considered to be the most hazardous (Mohan et al., 2014).

Fumes, primarily inhaled through the nose and mouth, are usually generated during welding and thermal metal cutting processes where the fume is formed when vaporised materials condense in cool air (Plog, 2002; Pickford and Davies, 2007). These processes liberate very fine solid particles of sizes usually smaller than $1 \mu \mathrm{m}$ in diameter which will generally agglomerate to form bigger clusters of particles (Plog, 2002; Zeidler-Erdely et al., 2012; Hariri et al., 2014).

Metal cutting is a process that is closely associated with welding processes and can be performed using gouging or lancing (Lyndon and Platcow; 2011). Gouging is used to prepare the weld groove or to remove defective welding zones and is done by melting the base metal with an electric arc and the subsequent removal of the molten metal through a jet of compressed air. Lancing severs or removes metal by the chemical reaction of pure oxygen with a base metal (Sasse et al., 1978; Lyndon and Platcow; 2011).

Metal fumes, which comprise a complex mixture of various toxic metals, can lead to adverse health effects through the inhalation thereof into the respiratory tract and may be categorised as acute or chronic health effects (Hartmann et al., 2014; Persoons et al., 2014; Sriram et al., 2015). Some of the acute health effects caused by the inhalation of metal fumes are metal fume fever, a decrease in lung function and pneumonia. Chronic health effects include asthma, bronchitis, neurological dysfunction, obstructive pulmonary disease, pneumoconiosis, pulmonary fibrosis and an increase in the prevalence of lung cancer (Antonini, 2003; Moroni and Viti, 2009; Wittczak et al., 2009; La Vecchia and Maestrelli, 2011; Sriram et al., 2015). 
The chemical composition of particles is also important to consider as a combination of different metals can cause adverse health effects (Hartmann et al., 2014; Sriram et al., 2015). The mixtures of metals present in these gouging and lancing fumes are unknown, with little or no published studies available to refer to.

The health effects caused by fumes occur because of the presence of different types of particles which can deposit in the respiratory tract and be absorbed from the respiratory tract. The region of deposition in the respiratory tract is determined by the particles' physical and chemical characteristics (Schaumlöffel, 2012; Hartmann et al., 2014). Particle size fractions that are biologically relevant in the occupational health community can be divided into three groups, namely inhalable $(<100 \mu \mathrm{m})$, thoracic $(<10 \mu \mathrm{m})$ and respirable $(<4 \mu \mathrm{m})$ fractions, based on the difference in their aerodynamic diameter (Cherrie and Aitken, 1999; Notø et al., 2016).

The respirable fraction also includes nanoparticles that are in the submicron range and are measured in nanometres (nm) (Oberdörster et al., 2005; Oberdörster et al., 2013). Nanoparticles could potentially cause more toxic responses than particles that are larger in size due to their ability to be absorbed into the blood circulation or de-agglomerate and elicit toxic effects in other regions of the body (Kang et al., 2011; Lehman-McKeeman, 2013; Nilsson et al., 2013). These particles have a large surface area per unit volume, which makes them highly reactive (e.g., as a catalyst) and increases their toxicological activity (Kang et al., 2011; Chang et al., 2013; Tokar et al., 2013). Characterising particle size fractions present in the metal cutting fumes is important for determining the presence of respirable- and nanoparticles. It is critical due to the ability of these particles to penetrate to the deepest structures of the lungs and cause adverse health effects (Cherrie and Aitken, 1999; Pickford and Davies, 2007; Kang et al., 2011; Lehman-McKeeman, 2013).

This study aimed to provide insight into the characterisation of metal fumes that are emitted from the metal cutting methods (gouging and lancing) with specific interest in the particle size fraction and metal composition thereof. Currently, inhalable and respirable particle size fractions of metal fumes are sampled at this mine without metal composition consideration. This study aimed to investigate thoracic and nano-sized particle fractions in addition to inhalable and respirable fractions as well as the metal composition of particles in the abovementioned fraction sizes. This information may be valuable to the mine as this will assist in determining whether the mine has to include the thoracic and/or nano-sized particle fractions during air monitoring in addition to inhalable and respirable sampling as well as to include metal composition and this information may be used to determine which precautions and control measures are required to be implemented to protect employees. 


\subsection{Methodology}

Inhalable, thoracic, respirable and nano-size particles were collected by using a randomised, side-by-side sampling stand. Samples were collected in two workshops during gouging and one workshop during lancing. Samplers were mounted at a minimum height of $1.3 \mathrm{~m}$ and a maximum height of $1.7 \mathrm{~m}$ which is representative of the height of workers standing up using a sampling station (Khattab and Levetin, 2008). Samplers were spaced out to ensure that they do not influence each other, and mounted on a sampling stand in a random fashion with the aid of Latin square randomisation (PennState Eberly College of Science, 2016). The sampling equipment used during this sampling process is summarised in Table 1.

Table 1: Different samplers used during sampling procedure.

\begin{tabular}{|l|l|c|l|}
\hline \multicolumn{1}{|c|}{ Sampler } & \multicolumn{1}{|c|}{$\begin{array}{c}\text { Particle size } \\
\text { fraction }\end{array}$} & Flow rate & \multicolumn{1}{c|}{ Filter used } \\
\hline $\begin{array}{l}\text { IOM (Institute of Occupational } \\
\text { Medicine) sampler }\end{array}$ & Inhalable fraction & $2.0 \mathrm{l} / \mathrm{min}$ & $\begin{array}{l}\text { MCE* filter, } 25 \mathrm{~mm}, \text { pore } \\
\text { size of } 0.8 \mu \mathrm{m} .\end{array}$ \\
\hline $\begin{array}{l}\text { GK2.69 cyclone sampler } \\
\text { sluminium respirable cyclone }\end{array}$ & Respirable fraction & $1.6 \mathrm{l} / \mathrm{min}$ & $\begin{array}{l}\text { MCE filter, } 37 \mathrm{~mm}, \text { pore } \\
\text { size of } 0.8 \mu \mathrm{m} .\end{array}$ \\
\hline $\begin{array}{l}\text { NRD (Nanoparticle Respiratory } \\
\text { Deposition) sampler }\end{array}$ & Nano-sized fraction & $2.5 \mathrm{l} / \mathrm{min}$ & $\begin{array}{l}\text { MCE filter, } 37 \mathrm{~mm}, \text { pore } \\
\text { size of } 0.8 \mu \mathrm{m} .\end{array}$ \\
\hline Open-faced filter cassette & $\begin{array}{l}\text { Particle size } \\
\text { distribution }\end{array}$ & $\begin{array}{l}\text { Nylon filters, } 25 \mathrm{~mm}, \\
\text { pore size of } 11 \mu \mathrm{m} .\end{array}$ \\
\hline
\end{tabular}

${ }^{*} \mathrm{MCE}-$ Mixed cellulose ester

Sampling pumps were calibrated at the respective flow rates of the different samplers by means of a Sensidyne Gilian Gilibrator-2, in line with the particle size fraction specific sampler. Pump calibration took place on site prior to the sampling and was verified after the sampling.

The gouging procedure was assessed at the maintenance workshop and the mining contractor's workshop and the lancing procedure at the secondary crusher. Gouging is performed on a daily basis; however, lancing is only done for two days every six weeks during the maintenance shutdown of the mine.

Inhalable, thoracic, respirable and nano-size particles were collected over a period of eight days. Samples were collected within $2 \mathrm{~m}$ from the source in the maintenance workshop and over a period of $45 \mathrm{~min}-106 \mathrm{~min}$, depending on work availability. Sample collection took 
place within $2 \mathrm{~m}$ from the source in the mining contractor's workshop and over a period of 47 min - 108 min, depending on work availability. Samples were collected at a range of between 5 and $10 \mathrm{~m}$ from the source in the secondary crusher workshop, due to space availability and over a period of $75 \mathrm{~min}-85 \mathrm{~min}$, depending on work availability. These samples were collected in the worst case scenario area (down-wind) which was predetermined using smoke tubes.

Open-faced $37 \mathrm{~mm}$ filter cassettes were also used to collect total inhalable particles in the worst case scenario area. These samples were analysed for the size distribution of the particles. One sample was collected per day at every area of sampling; therefore, a total of eight samples were collected for this purpose.

One field blank was collected for every 20 samples for every method; therefore, a total of four field blanks were collected.

The total number of samples collected for particle sizing and determining metal composition are shown in Table 2.

Table 2: Total samples at the various sampling areas.

\begin{tabular}{|c|c|c|c|c|c|c|c|}
\hline & & $\begin{array}{c}\text { Inhalable } \\
\text { fraction }\end{array}$ & $\begin{array}{l}\text { Thoracic } \\
\text { fraction }\end{array}$ & $\begin{array}{c}\text { Respirable } \\
\text { fraction }\end{array}$ & $\begin{array}{c}\text { Nanometre } \\
\text { fraction }\end{array}$ & $\begin{array}{c}\text { Particle } \\
\text { size range }\end{array}$ & $\begin{array}{l}\text { Number of } \\
\text { samples }\end{array}$ \\
\hline \multirow{9}{*}{ Method 1: } & \multicolumn{7}{|c|}{ Gouging } \\
\hline & \multicolumn{7}{|c|}{ Maintenance Workshop } \\
\hline & Day 2: & 2 & 2 & 2 & 2 & 1 & 9 \\
\hline & Day 3: & 1 & 1 & 1 & 1 & 1 & 5 \\
\hline & Day 8: & 2 & 2 & 2 & 2 & 1 & 9 \\
\hline & \multicolumn{7}{|c|}{ Mining Contractor's Workshop } \\
\hline & Day 5: & 2 & 2 & 2 & 2 & 1 & 9 \\
\hline & Day 6: & 2 & 2 & 2 & 2 & 1 & 9 \\
\hline & Day 7: & 1 & 1 & 1 & 1 & 1 & 5 \\
\hline \multirow{5}{*}{ Method 2: } & \multicolumn{7}{|c|}{ Lancing } \\
\hline & \multicolumn{7}{|c|}{ Primary and Secondary Crusher } \\
\hline & Day 1: & 3 & 3 & 3 & 3 & 1 & 13 \\
\hline & Day 4: & 3 & 3 & 3 & 3 & 1 & 13 \\
\hline & \multicolumn{6}{|c|}{ Total amount of samples } & 72 \\
\hline
\end{tabular}

This table does not include the control samples (field blanks). 
The pre- and post-weight of filters were used to determine the particulate mass concentration of the inhalable, thoracic, respirable and nanometre fractions that were present during gouging and lancing methods. These samples were sent for gravimetric analysis (Method: NIOSH 0500 and MDHS 14/3) as well as metal elements scan analysis (Method: OSHA ID125G and NIOSH 7300) to determine the total mass of inhalable, thoracic, respirable and nanometre particles and the metal composition of the fumes, respectively. An Inductively Coupled Plasma - Atomic Emission Spectroscopy (ICP-AES) was used to determine the metal elements present in the fumes. Analyses were done by a South African National Accreditation System (SANAS) accredited laboratory.

The eight samples that were collected using the open-faced $37 \mathrm{~mm}$ filter cassette were analysed to determine the particle size distribution range of all the collected particles. These samples were analysed by means of Dynamic Light Scattering using a Horiba LB 550 Particle Size Analyser.

\section{Statistical analysis}

For interpretation of results, basic descriptive statistics namely mean, minimum, maximum, median and standard deviation were utilised by means of IBM SPSS Statistics 23, Microsoft Excel and GraphPad Prism 5. The median was also included in the results since it provides an indication of the location of 50 percent of the data above and below this value. According to Horiba Instruments (2016), a single value, such as average, cannot describe data fully.

Normal distribution tests were performed on the data with regard to the concentration of the particle size fractions as well as the concentration of the various metals in order to determine the distribution of the data set. Tests indicated a skewed data set and data was log transformed. Data set skewness was not improved by means of log transformation and therefore; non-parametric statistical tests were utilised due to data not being normally distributed as well as the small sample size within each particle size fraction. The three workshops (maintenance workshop, mining contractor's workshop and secondary crusher workshop) were compared with each other with regard to particle size fractions and metal composition by means of a Kruskal-Wallis test. The two processes (gouging and lancing) were compared with regard to particle size fractions and metal composition using a Mann-Whitney $U$ test. All data with a $p$-value of $\leq 0.05$ was considered as statistically significant. Effect size tests were used to determine the practical significance (effect) between the workshops as well as the processes (small effect $\approx 0.1$; medium effect $\approx 0.3$; and large effect $\approx 0.5$ ) (Rosenthal, 
1991). Effect sizes can represent the meaningfulness of a difference between groups being evaluated and is used to distinguish practical significance from statistical significance (Steyn and Ellis, 2009). For the purpose of this study, the following formula and Cohen's guideline for interpreting effect sizes were used; $r=Z$-value divided by the square root of $n$ (total number of samples) (Ellis, 2009).

Measured values that were below the limit of detection, were substituted with values that were calculated using $\beta$-substitution (Ganser and Hewett, 2010). The $\beta$-substitution method is considered to be superior to the LOD divided by two and LOD divided by the square root of two methods, as these methods are considered to be biased (Ganser and Hewett, 2010). Five samples were collected for each fraction during gouging and six samples were collected for each fraction during lancing. Fifty percent of the data should be uncensored (available) to calculate substitution values using $\beta$-substitution. This means that more than half of the collected samples should have values of above the limit of detection. Therefore, where five or six samples were collected; only where three or more values were available, $\beta$-substitution was performed.

\section{Ethical considerations}

Static area monitoring was decided upon due to various reasons. It is unpractical and challenging to equip five personal sampling trains to a single worker. However, the main reason was to limit variation in personal sampling due to factors that cannot be controlled by the researcher. The aim was to determine particle size fractions and composition of the liberated fumes and not to compare concentrations against occupational exposure limits (OELs) in an attempt to evaluate worker exposure. Ethical approval was not required for this study since personal sampling was not conducted.

\subsection{Results}

The particulate mass concentration, metal composition and particle size distribution were determined for the maintenance workshop (gouging), the mining contractor's workshop (gouging) and the secondary crusher workshop (lancing). All statistical results will be discussed in the next paragraphs.

The following sections will be depicted in this order:

- Descriptive data for the concentration levels of the inhalable, thoracic and respirable particle size fractions;

- Descriptive data for the concentration levels of the nano-size particle size fraction; 
- Descriptive data for the nanometre particle size distribution;

- Descriptive data for the concentration levels of the metals present in the respirable particle size fraction;

- Descriptive data for the concentration levels of the metals present in the nano-size particle size fraction; and

- Particle size distribution figures and supporting SEM (scanning electron microscope) photos.

Descriptive data for the concentration levels of the inhalable, thoracic and respirable particle size fractions

Table 3 portrays the basic descriptive statistical data for the inhalable, thoracic and respirable fractions emitted during gouging and lancing processes. The contractor's workshop (gouging) indicated the highest mean ambient workplace concentration levels in the inhalable, thoracic and respirable fractions. 
Table 3: Descriptive statistical data for the inhalable, thoracic and respirable particle size fractions $\left(\mathrm{mg} / \mathrm{m}^{3}\right)$.

\begin{tabular}{|c|c|c|c|c|c|c|c|c|c|c|c|c|c|c|c|c|}
\hline \multirow{2}{*}{ Process and Workshop } & \multirow{2}{*}{$\mathbf{n}$} & \multicolumn{5}{|c|}{ Inhalable fraction } & \multicolumn{5}{|c|}{ Thoracic fraction } & \multicolumn{5}{|c|}{ Respirable fraction } \\
\hline & & Mean & Min & Max & Median & SD & Mean & Min & Max & Median & SD & Mean & Min & Max & Median & SD \\
\hline $\begin{array}{l}\text { Gouging: Maintenance } \\
\text { workshop }\end{array}$ & 5 & 4.48 & 1.27 & 12.73 & 2.99 & 4.62 & 4.22 & 1.83 & 11.29 & 2.38 & 3.99 & 2.36 & 1.16 & 5.57 & 1.67 & 1.81 \\
\hline $\begin{array}{c}\text { Gouging: Mining } \\
\text { contractor's workshop }\end{array}$ & 5 & 7.05 & 1.66 & 17.27 & 5.68 & 5.96 & 4.77 & 2.08 & 13.96 & 2.41 & 5.15 & 4.48 & 0.88 & 15.83 & 1.44 & 6.40 \\
\hline $\begin{array}{c}\text { Lancing: Secondary crusher } \\
\text { workshop }\end{array}$ & 6 & 4.06 & 2.34 & 5.60 & 4.40 & 1.30 & 3.44 & 2.82 & 4.01 & 3.43 & 0.39 & 2.46 & 1.89 & 3.24 & 2.38 & 0.46 \\
\hline
\end{tabular}


In Table 4 the basic descriptive statistical data is depicted for the nano-size fraction in fumes emitted during gouging and lancing processes in the maintenance workshop, the mining contractor's workshop and the secondary crusher workshop. The Table also includes a percentage value that portrays the total nano-sized particle concentration ( $\leq 300 \mathrm{~nm}$ ) found in the total NRD sampler. The NRD sampler used to sample the nano-sized particle fraction, samples all particles $\leq 4 \mu \mathrm{m}$ in the inertial impactor stage and particles $\leq 300 \mathrm{~nm}$ in the diffusion stage. Therefore, this shows the percentage of the nano-sized particle fraction in the total sampler, including particles up to $4 \mu \mathrm{m}$.

Table 4: Descriptive statistical data (concentrations, in $\mathrm{mg} / \mathrm{m}^{3}$ ) for the nano-sized particle fraction collected during the diffusion stage $(\leq 300 \mathrm{~nm})$ of the NRD sampler.

\begin{tabular}{|c|c|c|c|c|c|c|c|}
\hline $\begin{array}{c}\text { Process and } \\
\text { Workshop }\end{array}$ & $\mathbf{n}$ & Mean & Min & Max & Median & SD & $\begin{array}{c}\text { Nano-sized } \\
\text { particles in NRD } \\
\text { sampler (\%) }\end{array}$ \\
\hline $\begin{array}{c}\text { Gouging: } \\
\text { Maintenance } \\
\text { workshop }\end{array}$ & 5 & 2.02 & 1.62 & 2.86 & 1.87 & 0.50 & 14.42 \\
\hline $\begin{array}{c}\text { Gouging: } \\
\text { Mining } \\
\text { contractor's } \\
\text { workshop }\end{array}$ & 5 & 1.75 & 1.01 & 3.40 & 1.44 & 0.95 & 15.74 \\
\hline $\begin{array}{c}\text { Lancing: } \\
\text { Secondary } \\
\text { crusher } \\
\text { workshop }\end{array}$ & 6 & 1.96 & 1.60 & 2.10 & 2.04 & 0.19 & 14.67 \\
\hline
\end{tabular}

Descriptive data for the nanometre particle size distribution

In Table 5 the basic descriptive statistical data for the particle size distribution of nano-sized particles is depicted. Particle size distribution is used to determine the size or size range of particles and is important since the diameter of particles determine where in the respiratory tract deposition will take place and the subsequent clearance of particles (Particle Technology Lab, 2015). The contractor's workshop (gouging) indicated the largest mean and median particle size. 
Table 5: Descriptive statistical data for the nanometre particle size distribution (in nanometre).

\begin{tabular}{|c|c|c|c|c|c|c|}
\hline $\begin{array}{c}\text { Process and } \\
\text { Workshop }\end{array}$ & $\mathbf{n}$ & Mean & Min & Max & Median & SD \\
\hline $\begin{array}{c}\text { Gouging: } \\
\text { Maintenance } \\
\text { workshop }\end{array}$ & 9 & 149.60 & 35.60 & 675.30 & 45.30 & 29.47 \\
\hline $\begin{array}{c}\text { Gouging: } \\
\text { Mining } \\
\text { contractor's } \\
\text { workshop }\end{array}$ & 9 & 193.91 & 44.70 & 465.00 & 153.70 & 83.07 \\
\hline $\begin{array}{c}\text { Lancing: } \\
\text { Secondary } \\
\text { crusher } \\
\text { workshop }\end{array}$ & 6 & 32.33 & 23.90 & 44.50 & 31.70 & 7.17 \\
\hline
\end{tabular}

Particle size fractions were compared in the three workshops and indicated no significant differences in the inhalable, thoracic, respirable and nano-size fractions $(p=0.422 ; p=0.217$; $p=0.370 ; p=0.250$, respectively). Gouging and lancing processes did not statistically differ in the inhalable, respirable and nano-size fractions $(p=0.588 ; p=0.159 ; p=0.278$, respectively). Potential statistical differences were observed between the thoracic fractions liberated during gouging and lancing processes $(p=0.082)$.

Descriptive data for the concentration levels of the metals present in the respirable particle size fraction

Table 6 shows the basic descriptive statistical data for the metals present in the respirable fraction emitted during gouging and lancing processes. This data is included since the respirable fraction (defined as particles $<4 \mu \mathrm{m}$ ) includes the nano-size fraction. The inhalable and thoracic particle size fractions were not included to keep the information concise (included in Annexure A in Chapter 6). The grey blocks indicate that a metal was not present in the respirable fraction or that less than $50 \%$ of values were available and therefore; $\beta$-substitution could not be performed. The following metals were found in all three workshops in the respirable fraction: aluminium, calcium, chromium, copper, iron, magnesium, manganese, 
molybdenum, nickel, potassium, sodium, tin and zinc. Lancing processes also liberated arsenic and lead fumes. Iron showed the highest mean ambient workplace concentration levels in all three workshops.

Descriptive data for the concentration levels of the metals present in the nano-size particle size fraction

Table 7 depicts the basic descriptive statistical data for the metals present in the nano-size fraction emitted during gouging and lancing processes. The grey blocks indicate that a metal was not present in the nano-size fraction or that less than $50 \%$ of values were available and therefore; $\beta$-substitution could not be performed. The following metals were found in all three workshops in the nano-size fraction: calcium, chromium, copper, iron, magnesium, manganese, potassium, tin and titanium. Arsenic, lead, molybdenum and sodium were also present in fumes emitted during lancing processes. Iron showed the highest mean ambient workplace concentration levels in all three workshops.

The three workshops were compared to determine if the concentration of metals liberated in these workshops differed. Statistically significant differences were observed for copper, molybdenum and nickel between the three workshops $(p \leq 0.048)$, with copper and nickel higher in the mining contractor's workshop and molybdenum higher in the secondary crusher workshop. The two processes (i.e. gouging and lancing) were also compared to determine if the concentration of metals liberated during these processes differed. Statistically significant differences were observed for copper, iron, molybdenum and nickel between gouging and lancing ( $p \leq 0.05)$, with copper, iron and nickel emission higher during gouging processes and molybdenum emission higher during lancing processes. 
Table 6: Descriptive statistical data for various metals present in the respirable particle size fraction $\left(\mathrm{mg} / \mathrm{m}^{3}\right)$.

\begin{tabular}{|c|c|c|c|c|c|c|c|c|c|c|c|c|c|c|c|}
\hline \multirow{3}{*}{ Metal } & \multicolumn{15}{|c|}{ Respirable fraction } \\
\hline & \multicolumn{5}{|c|}{$\begin{array}{c}\text { Gouging }(\mathrm{n}=5) \\
\text { Maintenance workshop }\end{array}$} & \multicolumn{5}{|c|}{$\begin{array}{c}\text { Gouging }(n=5) \\
\text { Contractor's workshop }\end{array}$} & \multicolumn{5}{|c|}{$\begin{array}{c}\text { Lancing }(n=6) \\
\text { Secondary crusher workshop }\end{array}$} \\
\hline & Mean & Min & Max & Median & SD & Mean & Min & Max & Median & SD & Mean & Min & Max & Median & SD \\
\hline Aluminium (Al) & 0.0070 & 0.0004 & 0.0210 & 0.0054 & 0.0082 & 0.0040 & 0.0002 & 0.0081 & 0.0035 & 0.0039 & 0.0041 & 0.0003 & 0.0073 & 0.0047 & 0.0027 \\
\hline \multicolumn{16}{|l|}{ Antimony (Sb) } \\
\hline Arsenic (As) & & & & & & & & & & & 0.0027 & 0.0011 & 0.0040 & 0.0028 & 0.0013 \\
\hline \multicolumn{16}{|l|}{ Barium $(\mathrm{Ba})$} \\
\hline Calcium (Ca) & 0.1031 & 0.0188 & 0.3972 & 0.0354 & 0.1647 & 0.0477 & 0.0158 & 0.1211 & 0.0303 & 0.0434 & 0.0390 & 0.0147 & 0.0565 & 0.0430 & 0.0141 \\
\hline Chromium (Cr) & 0.0089 & 0.0048 & 0.0194 & 0.0067 & 0.0059 & 0.0112 & 0.0061 & 0.0272 & 0.0076 & 0.0090 & 0.0079 & 0.0048 & 0.0106 & 0.0081 & 0.0026 \\
\hline \multicolumn{16}{|l|}{ Cobalt (Co) } \\
\hline Copper (Cu) & 0.0279 & 0.0094 & 0.0731 & 0.0189 & 0.0260 & 0.0776 & 0.0207 & 0.2598 & 0.0321 & 0.1025 & 0.0098 & 0.0024 & 0.0186 & 0.0087 & 0.0081 \\
\hline Iron (Fe) & 1.0805 & 0.4475 & 2.7458 & 0.7448 & 0.9402 & 2.2405 & 0.5403 & 8.1593 & 0.7253 & 3.3198 & 1.3432 & 1.0362 & 1.8509 & 1.2765 & 0.2783 \\
\hline Lead $(\mathrm{Pb})$ & & & & & & & & & & & 0.0018 & 0.0008 & 0.0032 & 0.0017 & 0.0010 \\
\hline Magnesium (Mg) & 0.0057 & 0.0003 & 0.0081 & 0.0062 & 0.0032 & 0.0034 & 0.0010 & 0.0083 & 0.0017 & 0.0031 & 0.0025 & 0.0005 & 0.0053 & 0.0017 & 0.0019 \\
\hline Manganese (Mn) & 0.0693 & 0.0181 & 0.1898 & 0.0419 & 0.0695 & 0.1040 & 0.0179 & 0.3380 & 0.0583 & 0.1335 & 0.1035 & 0.0349 & 0.2110 & 0.0871 & 0.0775 \\
\hline \multicolumn{16}{|l|}{ Mercury $(\mathrm{Hg})$} \\
\hline Molybdenum (Mo) & 0.0033 & 0.0003 & 0.0104 & 0.0023 & 0.0042 & 0.0050 & 0.0008 & 0.0192 & 0.0016 & 0.0080 & 0.0131 & 0.0045 & 0.0261 & 0.0120 & 0.0094 \\
\hline Nickel (Ni) & 0.0035 & 0.0013 & 0.0080 & 0.0017 & 0.0030 & 0.0184 & 0.0006 & 0.0835 & 0.0028 & 0.0364 & 0.0026 & 0.0007 & 0.0051 & 0.0027 & 0.0016 \\
\hline \multicolumn{16}{|l|}{ Palladium $(\mathrm{Pd})$} \\
\hline Potassium (K) & 0.0105 & 0.0057 & 0.0181 & 0.0095 & 0.0047 & 0.0131 & 0.0026 & 0.0311 & 0.0124 & 0.0109 & 0.0139 & 0.0066 & 0.0363 & 0.0107 & 0.0112 \\
\hline \multicolumn{16}{|l|}{ Selenium (Se) } \\
\hline \multicolumn{16}{|l|}{ Silver $(\mathrm{Ag})$} \\
\hline Sodium (Na) & 0.2020 & 0.0704 & 0.4937 & 0.0857 & 0.1853 & 0.1686 & 0.1400 & 0.2176 & 0.1647 & 0.0299 & 0.0973 & 0.0002 & 0.2025 & 0.0975 & 0.0847 \\
\hline \multicolumn{16}{|l|}{ Strontium (Sr) } \\
\hline $\operatorname{Tin}(\mathrm{Sn})$ & 0.0368 & 0.0261 & 0.0564 & 0.0333 & 0.0121 & 0.0428 & 0.0265 & 0.0689 & 0.0431 & 0.0170 & 0.0294 & 0.0150 & 0.0413 & 0.0311 & 0.0108 \\
\hline Titanium (Ti) & 0.0031 & 0.0007 & 0.0058 & 0.0027 & 0.0022 & & & & & & & & & & \\
\hline \multicolumn{16}{|l|}{ Tungsten (W) } \\
\hline Zinc (Zn) & 0.0103 & 0.0012 & 0.0291 & 0.0040 & 0.0117 & 0.0037 & 0.0021 & 0.0078 & 0.0027 & 0.0024 & 0.0045 & 0.0024 & 0.0067 & 0.0046 & 0.0014 \\
\hline Zirconium $(\mathrm{Zr})$ & & & & & & & & & & & & & & & \\
\hline
\end{tabular}


Table 7: Descriptive statistical data for various metals present in the nanometre particle size fraction $\left(\mathrm{mg} / \mathrm{m}^{3}\right)$.

\begin{tabular}{|c|c|c|c|c|c|c|c|c|c|c|c|c|c|c|c|}
\hline \multirow{3}{*}{ Metal } & \multicolumn{15}{|c|}{ Nano-sized fraction } \\
\hline & \multicolumn{5}{|c|}{$\begin{array}{c}\text { Gouging }(n=5) \\
\text { Maintenance workshop }\end{array}$} & \multicolumn{5}{|c|}{$\begin{array}{c}\text { Gouging }(n=5) \\
\text { Contractor's workshop }\end{array}$} & \multicolumn{5}{|c|}{$\begin{array}{c}\text { Lancing }(n=6) \\
\text { Secondary crusher workshop }\end{array}$} \\
\hline & Mean & Min & Max & Median & SD & Mean & Min & Max & Median & SD & Mean & Min & Max & Median & SD \\
\hline Aluminium (Al) & 0.0030 & 0.0002 & 0.0054 & 0.0035 & 0.0024 & 0.0011 & 0.0003 & 0.0022 & 0.0005 & 0.0009 & & & & & \\
\hline \multicolumn{16}{|l|}{ Antimony (Sb) } \\
\hline Arsenic (As) & & & & & & & & & & & 0.0006 & 0.0003 & 0.0009 & 0.0005 & 0.0003 \\
\hline \multicolumn{16}{|l|}{ Barium $(\mathrm{Ba})$} \\
\hline Calcium (Ca) & 0.0292 & 0.0056 & 0.0364 & 0.0342 & 0.0133 & 0.0232 & 0.0031 & 0.0416 & 0.0255 & 0.0255 & 0.0602 & 0.0114 & 0.1907 & 0.0409 & 0.0654 \\
\hline Chromium (Cr) & 0.0020 & 0.0002 & 0.0054 & 0.0011 & 0.0022 & 0.0017 & 0.0004 & 0.0042 & 0.0014 & 0.0015 & 0.0013 & 0.0003 & 0.0026 & 0.0012 & 0.0011 \\
\hline \multicolumn{16}{|l|}{ Cobalt (Co) } \\
\hline Copper (Cu) & 0.0118 & 0.0023 & 0.0185 & 0.0123 & 0.0070 & 0.0126 & 0.0071 & 0.0266 & 0.0091 & 0.0081 & 0.0018 & 0.0006 & 0.0032 & 0.0017 & 0.0011 \\
\hline Iron (Fe) & 0.3069 & 0.0583 & 0.4088 & 0.3631 & 0.1416 & 0.2114 & 0.0815 & 0.5316 & 0.1190 & 0.1858 & 0.2986 & 0.2405 & 0.3327 & 0.3176 & 0.0373 \\
\hline Lead $(\mathrm{Pb})$ & & & & & & & & & & & 0.0005 & 0.0003 & 0.0009 & 0.0004 & 0.0002 \\
\hline Magnesium (Mg) & 0.0064 & 0.0035 & 0.0121 & 0.0052 & 0.0035 & 0.0057 & 0.0014 & 0.0113 & 0.0068 & 0.0042 & 0.0151 & 0.0050 & 0.0474 & 0.0079 & 0.0162 \\
\hline Manganese (Mn) & 0.0219 & 0.0024 & 0.0365 & 0.0255 & 0.0132 & 0.0149 & 0.0030 & 0.0323 & 0.0105 & 0.0120 & 0.0175 & 0.0102 & 0.0271 & 0.0168 & 0.0070 \\
\hline \multicolumn{16}{|l|}{ Mercury $(\mathrm{Hg})$} \\
\hline Molybdenum (Mo) & & & & & & & & & & & 0.0027 & 0.0015 & 0.0043 & 0.0025 & 0.0013 \\
\hline Nickel (Ni) & 0.0007 & 0.0006 & 0.0009 & 0.0006 & 0.0001 & & & & & & 0.0005 & 0.0004 & 0.0007 & 0.0005 & 0.0001 \\
\hline \multicolumn{16}{|l|}{ Palladium $(\mathrm{Pd})$} \\
\hline Potassium (K) & 0.0063 & 0.0045 & 0.0109 & 0.0056 & 0.0026 & 0.0062 & 0.0017 & 0.0113 & 0.0057 & 0.0038 & 0.0052 & 0.0003 & 0.0126 & 0.0040 & 0.0045 \\
\hline Selenium (Se) & 0.0010 & 0.0004 & 0.0018 & 0.0010 & 0.0006 & & & & & & 0.0009 & 0.0002 & 0.0024 & 0.0006 & 0.0009 \\
\hline \multicolumn{16}{|l|}{ Silver $(\mathrm{Ag})$} \\
\hline Sodium (Na) & & & & & & & & & & & 0.0141 & 0.0001 & 0.0584 & 0.0061 & 0.0226 \\
\hline \multicolumn{16}{|l|}{ Strontium (Sr) } \\
\hline $\operatorname{Tin}(S n)$ & 0.0053 & 0.0003 & 0.0147 & 0.0012 & 0.0064 & 0.0022 & 0.0003 & 0.0067 & 0.0005 & 0.0028 & 0.0018 & 0.0001 & 0.0050 & 0.0009 & 0.0021 \\
\hline Titanium (Ti) & 0.0040 & 0.0002 & 0.0123 & 0.0020 & 0.0048 & 0.0020 & 0.0002 & 0.0056 & 0.0015 & 0.0022 & 0.0023 & 0.0001 & 0.0056 & 0.0017 & 0.0025 \\
\hline \multicolumn{16}{|l|}{ Tungsten (W) } \\
\hline Zinc $(Z n)$ & 0.0292 & 0.0001 & 0.1105 & 0.0021 & 0.0476 & & & & & & & & & & \\
\hline Zirconium $(\mathrm{Zr})$ & & & & & & & & & & & & & & & \\
\hline
\end{tabular}


Figure 1 illustrates the particle size distribution range of fumes emitted during gouging and lancing processes in three workshops. Particle size distribution is used as an index (in the form of a figure or table) to depict the frequency in percentage of particles present in various particle size intervals (Shimadzu Corporation, 2016). For example, gouging in the maintenance workshop on day 2 showed a large amount of particles in a narrow range (23\% of particles were $44.3 \mathrm{~nm}$ in diameter) and gouging in the contactor's workshop on day 5 showed particles in a wide range of sizes $(50.7-2268.7 \mathrm{~nm})$.

Figure 2 supports Figure 1 by illustrating various particles in the nano-size fraction. Figure 2 (a) shows a particle with a diameter of $300-400 \mathrm{~nm}$. Figure 2 (b) and (c) shows various nanoparticles as well as particle agglomeration, creating particles with larger diameters. 
a)

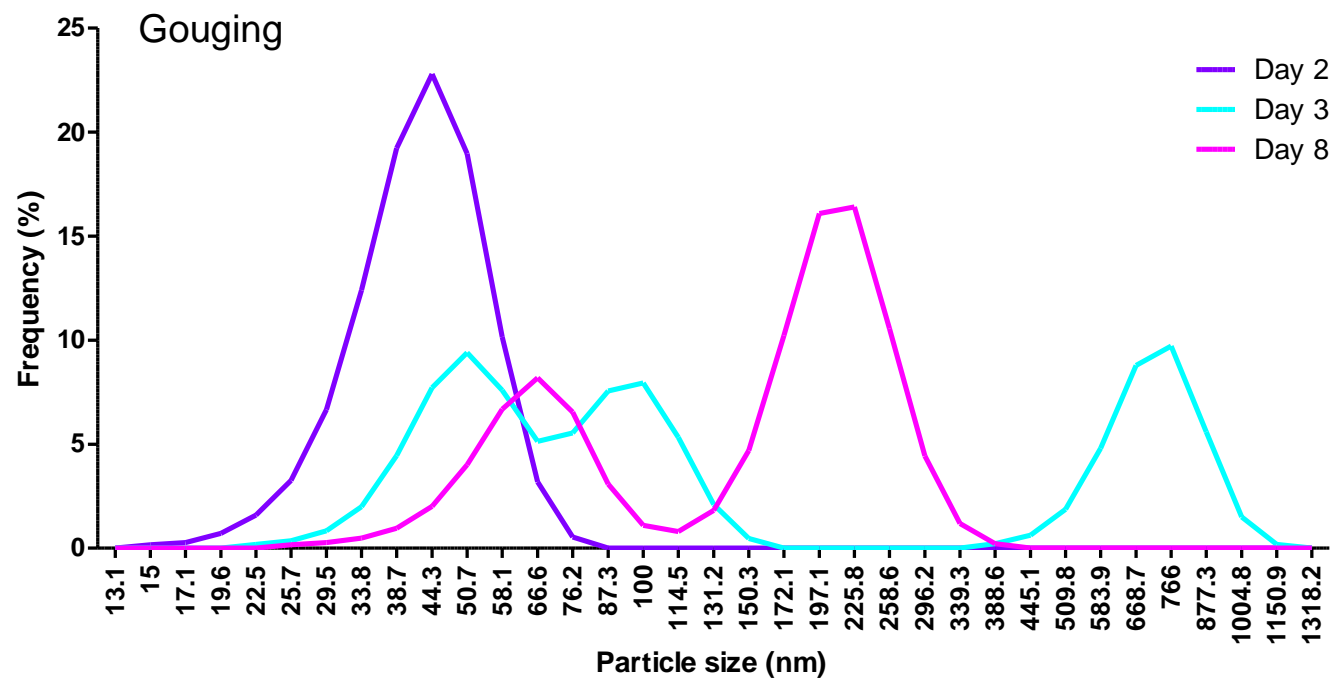

b)

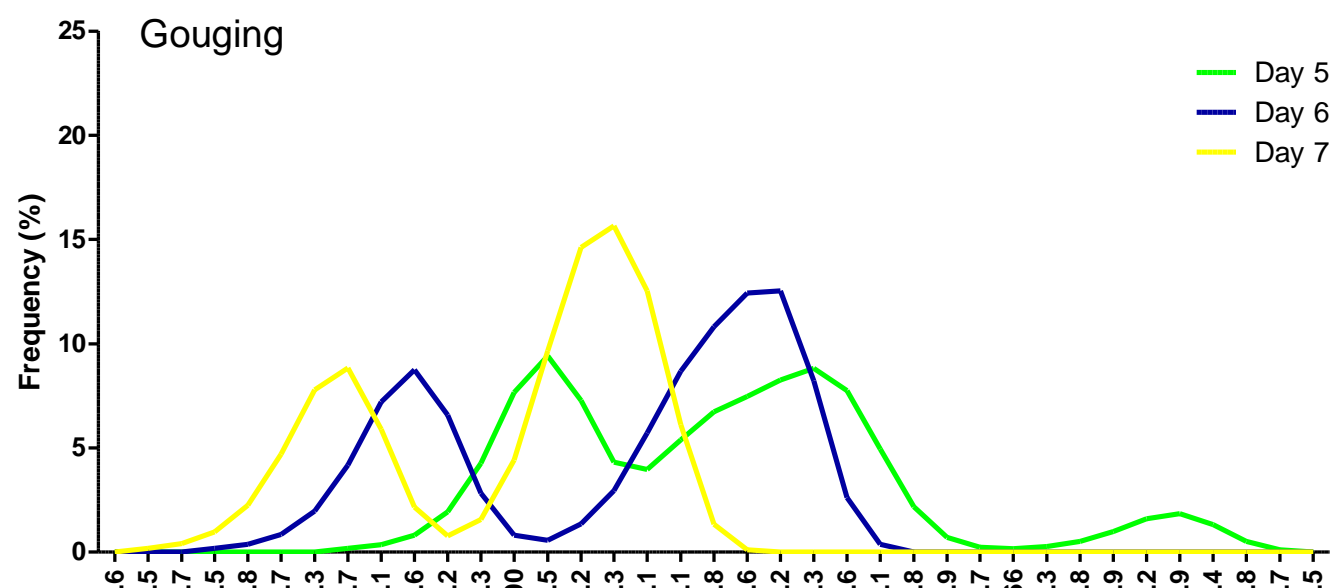

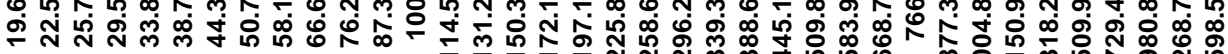
Particle size $(\mathrm{nm})$

c)

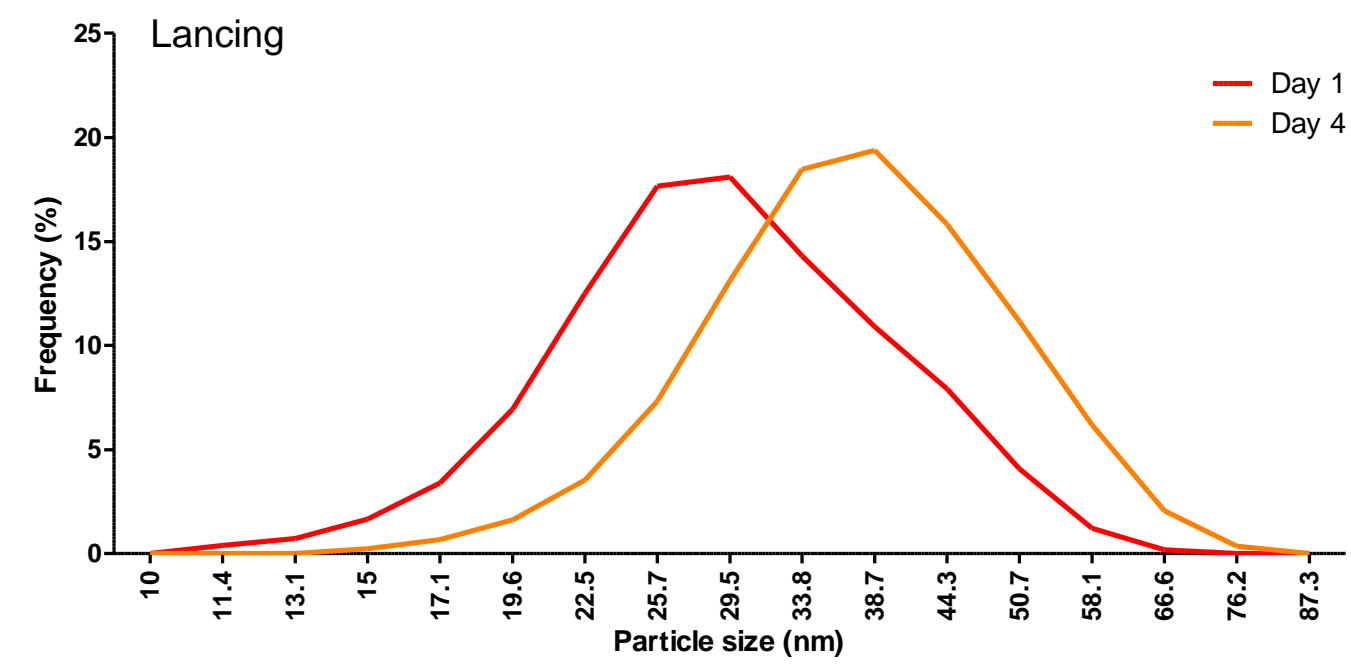

Figure 1: Particle size distribution of fumes emitted at the (a) maintenance workshop during gouging, (b) mining contractor's workshop during gouging and (c) secondary crusher workshop during lancing. 
a)
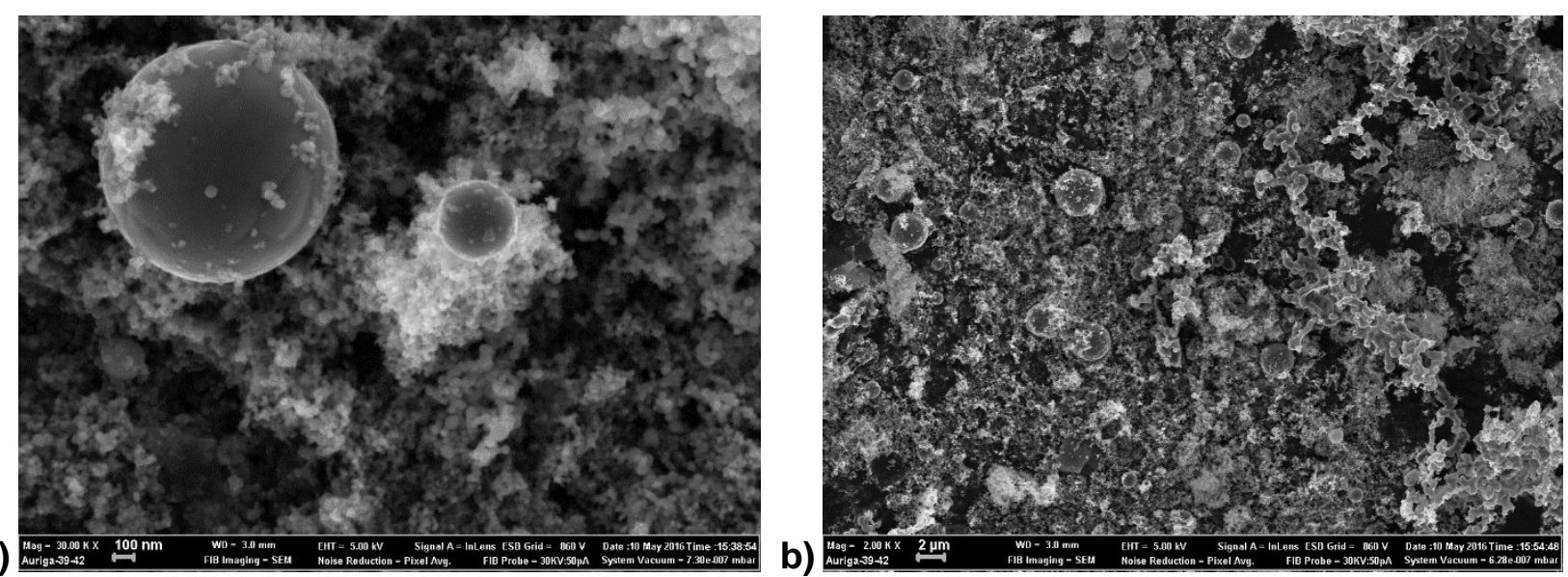

b)

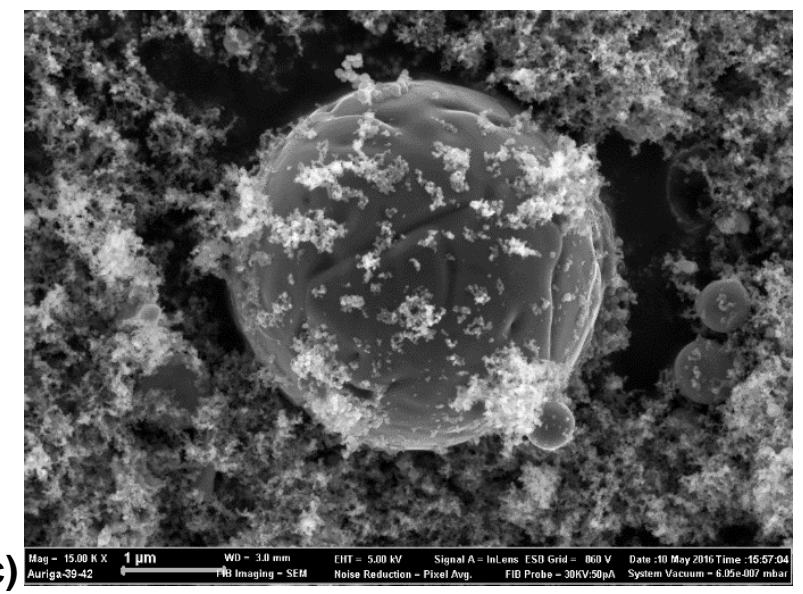

Figure 2: $\quad$ SEM (scanning electron microscopy) photos of particulate matter present in fumes.

\section{Effect sizes}

Effect sizes are used to distinguish practical significance from statistical significance and can represent the significance of a difference between evaluated groups (Steyn and Ellis, 2009). Statistical significance is determined using a p-value; however, a value may show no statistical significant difference and still show practically significant difference, by indicating a small, medium or large effect size.

A small effect size was determined for the inhalable fraction between the two processes, whereas medium effect sizes were determined for the thoracic, respirable and nano-size fractions, indicating a medium practical difference between gouging and lancing for these three fraction sizes.

Small, medium and large effects were established for the particle size fractions in the three workshops (depicted in Table 8). A large practical difference was found between the maintenance workshop and the secondary crusher workshop for the respirable fraction. 
Table 8: Effect sizes determined for fraction sizes in three workshops.

\begin{tabular}{|l|c|c|c|}
\hline \multirow{2}{*}{ Particle size fraction } & \multicolumn{2}{|c|}{ Effect size } \\
\cline { 2 - 4 } & $\begin{array}{c}\text { Comparison between } \\
\text { maintenance and } \\
\text { contractor's workshops }\end{array}$ & $\begin{array}{c}\text { Comparison between } \\
\text { maintenance and } \\
\text { secondary crusher } \\
\text { workshops }\end{array}$ & $\begin{array}{c}\text { Comparison between } \\
\text { contractor's and } \\
\text { secondary crusher } \\
\text { workshops }\end{array}$ \\
\hline Inhalable fraction & 0.3 (medium) & 0.1 (small) & 0.4 (medium) \\
\hline Thoracic fraction & 0.1 (small) & 0.4 (medium) & 0.4 (medium) \\
\hline Respirable fraction & 0.2 (small) & $\mathbf{0 . 5}$ (large) & 0.2 (small) \\
\hline Nano-size fraction & 0.4 (medium) & 0.1 (small) & 0.4 (medium) \\
\hline
\end{tabular}

The two processes were compared to determine if the concentration of metals liberated by these processes differed. A small effect was determined for aluminium, calcium, chromium, iron, lead, magnesium, manganese, potassium, selenium, tin, titanium and zinc between gouging and lancing processes, indicating small to no practical differences between gouging and lancing. Medium effect sizes were determined between these two processes for nickel and sodium and large effect sizes for copper and molybdenum, practical differences in the concentration of the metals liberated between the two processes.

\subsection{Discussion}

This study was conducted to determine particle size and metal composition of airborne particulate matter present in metal fumes that are emitted during gouging and lancing processes. These processes were conducted in three workshops at a South African mine (maintenance workshop, mining contractor's workshop and secondary crusher workshop).

The results from the gravimetric analysis of the collected samples indicated the presence of inhalable, thoracic, respirable and nano-size particles in the fumes emitted during gouging and lancing. The aerodynamic diameter of airborne particulate matter present in metal fumes plays an important role in the deposition and subsequent clearance of particulate matter from the respiratory tract and this will determine the amount of particles that will deposit in the respiratory tract of a worker (Wilson et al., 2002; Pickford and Davies, 2007, Tian et al., 2016). Respirable and nanoparticles found in this study suggests a potential high risk to workers since these particles could deposit in the alveolar region of the lungs and may be absorbed into the blood circulation, from where they may be transported to other regions of the body (LehmanMcKeeman, 2013).

As seen in the results, nanoparticles are present in the fumes liberated during gouging and lancing processes. It is important to take note of nanoparticles, since little research has been done in this field. Elihn and Berg (2009) conducted a study in seven industrial plants to investigate the presence of nanoparticles. They found that hot processes such as welding and metal cutting 
methods generate high concentrations of nanoparticles with an aerodynamic diameter in the nanometre range, a finding supported by results obtained during this study with sizes ranging between 11.4 and $2268.7 \mathrm{~nm}$. Nanoparticles were generated during gouging and lancing processes and were released into the work environment, possibly exposing maintenance workers as well as other employees working in the immediate vicinity to these particles. Nanoparticles can migrate to the alveolar region of the lungs and be absorbed into the blood, where they will move through the body and may elicit toxic effects at other target organs and regions of the body (Kang et al., 2011; Lehman-McKeeman, 2013). The clearance of nanoparticles from the lungs is also poor as these particles are too small to be recognised and phagocytised by alveolar macrophages (Oberdörster et al., 2013). These unique characteristics may cause challenges in addressing the potential health effects and impact of nanoparticles, since the health effects caused by nano-size metals are still unknown.

As part of particle size characterisation, particle size distribution analysis was conducted to determine the size of particles present in gouging and lancing fumes. Particle size distribution is an index that indicates the frequency of particles present in various particle size intervals (Shimadzu Corporation, 2016). Particle size distribution analysis supported the presence of nanoparticles, indicating a range of 23.9 to $675.3 \mathrm{~nm}$. Lancing could be considered as potentially more hazardous than gouging, since mean particle sizes are smaller than with gouging, in terms of nanoparticles. Lancing processes liberate particles with an average size of $32.3 \mathrm{~nm}$ and gouging processes liberate particles with an average size of $171.8 \mathrm{~nm}$. Gouging fumes contain particles with a wide range of sizes, whereas lancing fumes contain a high frequency of particles in a small range. The results of this study indicated that workers are mostly exposed to particle sizes in a narrow range. Since nanotoxicology currently remains an unfamiliar field, it is possible that there may be adverse health effects outside of the respiratory system such as translocation to the blood-brain barrier and this may subsequently cause neurological dysfunction (LehmanMcKeeman, 2013).

Due to the lack of information regarding nanoparticles, exposure to these particles should be minimised or eliminated. Literature shows that nanoparticles may remain airborne for longer periods of time than their larger counterparts if they are not contained. These particles will follow surrounding airflow in a workshop and are highly mobile; therefore, they can be contained using ventilation systems, such as local exhaust ventilation with a high-efficiency particulate air (HEPA) filter (Schulte et al., 2008). Personal protective equipment (PPE) may be used in addition to other control measures as the health risk profiles of nanoparticles are still unknown (Schulte et al., 2008). This PPE may include shoes made of low permeability material, trousers without turn-ups, clothes made out of woven fibres and $\mathrm{NIOSH}$-certified air-purifying respirators with $\mathrm{P} 100$ filtering media in a cartridge (Rengasamy et al., 2008; Shaffer and Rengasamy, 2009; Del Castillo, 2013). 
This study also aimed to determine metal composition of gouging and lancing fumes, since the composition of the base metals that were gouged or lanced were unknown and there is little information available on gouging and lancing processes. Metal composition of inhalable and thoracic particle size fractions were also determined; however, to keep the information concise, this was not included in the results (included in Annexure A in Chapter 6). The metals that are discussed in the following section were present in either the respirable or nano-size fraction, or both.

According to literature, chromium (Cr), cobalt (Co), iron (Fe), lead (Pb), manganese (Mn), nickel $(\mathrm{Ni})$, titanium $(\mathrm{Ti})$ and zinc $(\mathrm{Zn})$ may be present in fumes emitted during hot processes, such as metal cutting (Hartmann et al., 2014; Persoons et al., 2014; Sriram et al., 2015). As shown in the results, these metals were all present in the fumes emitted during gouging and lancing, along with various other metals. The following prominent metals were present in the fumes emitted during gouging and lancing: aluminium, arsenic, chromium, cobalt, iron, lead, manganese, nickel, and tin. These metals all have cancer classifications or notable health effects (IARC, 2012a; IARC, 2012b; Tokar et al., 2013).

Aluminium, arsenic, hexavalent chromium, iron and nickel are classified as Group 1 human carcinogens (IARC, 2012a; IARC, 2012b). Nickel is a Type IV skin sensitiser (Tokar et al., 2013). Lead is classified as Group 2A (inorganic lead) and Group 3 (organic lead) carcinogens and may lead to the development of peripheral neuropathy (IARC, 2006b; ATSDR, 2010; Tokar et al., 2013). Cobalt is classified as a Group 2B human carcinogen and may lead to the development of hard metal lung disease and may cause a decrease in lung function (IARC, 2006a). Manganese may lead to the development of bronchitis, asthma and manganism (a neurological disorder similar to Parkinson's disease) (IARC, 2012b; Tokar et al., 2013; Sriram et al., 2015). Tin may lead to the development of pulmonary fibrosis as well as stannosis, a benign non-fibrotic pneumoconiosis (Liu et al., 2012; ATSDR, 2014).

Antimony and mercury were only found in fumes liberated during lancing procedures. Antimony is classified as a Group 2B human carcinogen and may result in the development of antimoniosis (a form of pneumoconiosis) (IARC, 1989; Tokar et al., 2013). Mercury is classified as a Group 2B (methyl mercury compounds) and Group 3 (metallic mercury and inorganic mercury) human carcinogen and may lead to the development of corrosive bronchitis and could be associated with effects on the central nervous system (IARC, 1993; Tokar et al., 2013; WHO, 2016).

Metal composition is an important factor to take into account, since it will influence the risk of exposure of workers and it may influence the control measures that could be implemented by the mine. Metals liberated during gouging and lancing processes will influence the toxicological profile 
of the fume. Various metals have different health effects and may cause additive effects which can exacerbate adverse health effects (Hartmann et al., 2014; Sriram et al., 2015).

Carbon $(\mathrm{C})$, sulphur $(\mathrm{S})$, phosphorous $(\mathrm{P})$ and silicon dioxide $\left(\mathrm{SiO}_{2}\right)$ were also present in the metal cutting fumes; however, it will not be discussed, since they are not metal elements and are not relevant to this study. It should be noted that all of the samples were collected through area sampling and, therefore, cannot be seen as a representation of personal exposure, as this was not the aim of the study.

\subsection{Conclusions}

This study provided an understanding of the ambient workplace concentration levels during gouging and lancing processes in three workshops with specific reference to different particle size fractions and metal compositions of fumes emitted. No prior knowledge existed concerning the particle size (especially nano-size fraction) and metal composition of the airborne particulate matter present in metal fumes specifically emitted during gouging and lancing.

This study is novel by indicating the presence of nanoparticles (submicron particles) in the ambient particulate matter emitted during gouging and lancing. These particles may pose a potentially higher risk to workers, because of their smaller size and unknown health effects. As discussed earlier, clearance of these particles is poor and may present a significant health risk to maintenance workers. The metal composition of the fumes emitted during gouging and lancing plays a role of great importance in the toxicological effects on the maintenance workers as these metals may accumulate in the body and cause various health effects in different regions of the body.

The findings of this study indicate that maintenance workers are exposed to various hazardous metals in all of the particle size fractions, including nanoparticles. Both processes liberate nanosized particles; however, lancing processes liberate smaller particles than gouging processes. Lancing processes also liberate more metals than gouging processes. Based on these results, it may be deduced that lancing processes can be more hazardous than gouging processes. This study shows that the nano-size fraction and possibly the thoracic fraction should also be included during future personal exposure assessments and monitoring in addition to inhalable and respirable sampling. This information may assist the mine to implement control measures as well as precautions, specifically for nanoparticle exposure, to protect their workers' health. These may include ventilation systems (local exhaust ventilation), administrative controls (reduction of work periods and/or rotation of workers) and PPE (specific to nanoparticles). 


\section{Acknowledgements}

This study was funded by a world class mining group.

The authors would like to thank Ms. Marike Cockeran for her help and guidance with the analysis and interpretation of the data for this study. 


\subsection{References}

Agency for Toxic Substances and Disease Registry (ATSDR). (2010) Lead toxicity. Available from: URL: http://www.atsdr.cdc.gov/csem/csem.asp?csem=7\&po=10 (accessed 18 July 2016) Agency for Toxic Substances and Disease Registry (ATSDR). (2014) Toxic Substances Portal Tin. Available from: URL: http://www.atsdr.cdc.gov/toxfaqs/tf.asp?id=542\&tid=98\#bookmark05 (accessed 16 June 2016)

Antonini JM. (2003) Health effects of welding. Crit Rev Toxicol; 33: 61-103.

Bureau of Labor Statistics, U.S. Department of Labor. (2014) Occupational outlook handbook: welding, soldering, and brazing workers. Available from: URL: http://www.bls.gov/ooh/production/welders-cutters-solderers-and-brazers.htm $\quad$ (accessed 4 September 2015)

Chang C, Demokritou P, Shafer M, Christiani D. (2013) Physicochemical and toxicological characteristics of welding fume derived particles generated from real time welding processes. Environ Sci - Proc Imp; 15: 214-224.

Cherrie JW, Aitken RJ. (1999) Measurement of human exposure to biologically relevant fractions of the total aerosol. Occup Environ Med; 56: 747-752.

Del Castillo AM. (2013) Nanomaterials and workplace health \& safety: What are the issues for workers? Brussels: European Trade Union Institute. p. 23-24. ISBN 978-2-87452-288-8.

Elihn K, Berg P. (2009) Ultrafine particle characteristics in seven industrial plants. Ann Occup Hyg; 53:475-484.

Ellis PD. (2009) Thresholds for interpreting effect sizes. Available from: URL: http://www.polyu.edu.hk/mm/effectsizefaqs/thresholds_for_interpreting_effect_sizes2.html (accessed 14 October 2016)

Ganser GH, Hewett P. (2010) An accurate substitution method for analyzing censored data. J Occup Environ Hyg; 7: 233-244.

Hariri A, Azreen N, Abdull N et al. (2014) Determination of customer requirement for welding fumes index development in automotive industries by using quality function deployment approach. Int J Automot Mech Eng; 9: 1609-1619. 
Hartmann L, Bauer M, Bertram J et al. (2014) Assessment of the biological effects of welding fumes emitted from metal inert gas welding processes of aluminium and zinc-plated materials in humans. Int J Hyg Envir Health; 217: 160-168.

Horiba Instruments. (2016) A guidebook to particle size analysis. Available from: URL: https://www.horiba.com/fileadmin/uploads/Scientific/eMag/PSA/Guidebook/pdf/PSA_Guidebook .pdf (accessed 27 September 2016)

IARC (International Agency for Research on Cancer). (1989) Monographs on the evaluation of carcinogenic risks to humans (Volume 47): Some organic solvents, resin monomers and related compounds, pigments and occupational exposures in paint manufacture and painting. Available from: URL: http://monographs.iarc.fr/ENG/Monographs/vol47/mono47.pdf (accessed 16 June 2016)

IARC (International Agency for Research on Cancer). (1993) Monographs on the evaluation of carcinogenic risks to humans (Volume 58): Beryllium, cadmium, mercury and exposures in the glass manufacturing industry. Available from: URL: https://monographs.iarc.fr/ENG/Monographs/vol58/mono58.pdf (accessed 16 June 2016)

IARC (International Agency for Research on Cancer). (2006a) Monographs on the evaluation of carcinogenic risks to humans (Volume 86): Cobalt in Hard Metals and Cobalt Sulfate, Gallium Arsenide, Indium Phosphide and Vanadium Pentoxide. Available from: URL: http://monographs.iarc.fr/ENG/Monographs/vol86/mono86.pdf (accessed 10 May 2015)

IARC (International Agency for Research on Cancer). (2006b) Monographs on the evaluation of carcinogenic risks to humans (Volume 87): Inorganic and Organic Lead Compounds. Available from: URL: http://monographs.iarc.fr/ENG/Monographs/vol87/mono87.pdf (accessed 10 May 2015)

IARC (International Agency for Research on Cancer). (2012a) Monographs on the evaluation of carcinogenic risks to humans (Volume 100C): Arsenic, metals, fibres, and dusts. Available from: URL: http://monographs.iarc.fr/ENG/Monographs/vol100C/mono100C.pdf (accessed 10 May 2015)

IARC (International Agency for Research on Cancer). (2012b) Monographs on the evaluation of carcinogenic risks to humans (Volume 100F): Chemical agents and related occupations. Available from: URL: http://monographs.iarc.fr/ENG/Monographs/vol100F/mono100F.pdf (accessed 10 May 2015) 
Kang GS, Gillespie PA, Gunnison A et al. (2011) Long-term inhalation exposure to nickel nanoparticles exacerbated atherosclerosis in a susceptible mouse model. Environ Health Persp; 119: 176-181.

Khattab A, Levetin E. (2008) Effect of sampling height on the concentration of airborne fungal spores. Ann Allergy Ashtma Immunol; 101: 529-534.

La Vecchia GM, Maestrelli P. (2011) New welding processes and health effects of welding (Italian). G Ital Med Lav Ergon; 33: 252-256.

Lehman-McKeeman LD. (2013) Absorption, distribution and excretion of toxicants. In Klaassen CD, editor. Casarett \& Doull's Toxicology: The Basic Science of Poison. China: McGraw-Hill. p. 153-183. ISBN 978-0-07-176923-5.

Liu HH, Chen CY, Chen Gl et al. (2012) Relationship between indium exposure and oxidative damage in workers in indium tin oxide production plants. Int Arch Occup Environ Health; 85: 447453.

Lyndon GS, Platcow PA. (2011) Welding and thermal cutting. Available from: URL: http://www.ilo.org/iloenc/part-xiii/metal-processing-and-metal-working-industry/metalprocessing-and-metal-working/item/676-welding-and-thermal-cutting (accessed 6 July 2015)

Mohan S, Sivapirakasam SP, Bineesh P, Satpathy KK. (2014) Strategies for controlling welding fumes at the source - A review. Appl Mech Mater; 592-594: 2539-2545.

Moroni B, Viti C. (2009) Grain size, chemistry, and structure of fine and ultrafine particles in stainless steel welding fumes. Aerosol Sci; 40: 938-949.

Nilsson PT, Isaxon C, Eriksson AC et al. (2013) Nano-objects emitted during maintenance of common particle generators: direct chemical characterization with aerosol mass spectrometry and implications for risk assessments. J Nanopart Res; 15: 1-16.

Notø HP, Nordby KC, Eduard W. (2016) Relationships between personal measurements of 'total' dust, respirable, thoracic, and inhalable aerosol fractions in the cement production industry. Ann Occup Hyg; 60: 453-466.

Oberdörster G, Kane AB, Klaper RD, Hurt RH. (2013) Nanotoxicology. In Klaassen CD, editor. Casarett \& Doull's Toxicology: The Basic Science of Poison. China: McGraw-Hill. p. 1189-1229. ISBN 978-0-07-176923-5. 
Oberdörster G, Oberdörster E, Oberdörster J. (2005) Nanotoxicology: An emerging discipline evolving from studies of ultrafine particles. Environ Health Persp; 113: 823-839.

Particle Technology Lab. (2015) Particle size distribution analyses. Available from: URL: http://particletechlabs.com/services/particle-size-distribution-analyses (accessed 27 September 2016)

PennState Eberly College of Science. (2016) The latin square design. Available from: URL: https://onlinecourses.science.psu.edu/stat503/node/21 (accessed 4 April 2016)

Persoons R, Arnoux D, Monssu T et al. (2014) Determinants of occupational exposure to metals by gas metal arc welding and risk management measures: A bio monitoring study. Toxicol Lett; 231: 135-141.

Pickford G, Davies B. (2007) Aerosols. In Tillman C, editor. Principles of Occupational Health \& Hygiene: An Introduction. Singapore: ANL Printers. p. 125-171. ISBN 9781741750584.

Plog BA. (2002) Overview of Industrial Hygiene. In Plog BA, Quinlan PJ, editors. Fundamentals of Industrial Hygiene. United States of America: National Safety Council. p. 3-32. ISBN 0-87912216-1.

Rengasamy S, King WP, Eimer BC, Shaffer RE. (2008) Filtering performance of NIOSH-approved N95 and P100 filtering facepiece respirators against 4 to 30 nanometer-size nanoparticles. J Occup Environ Hyg; 5: 556-564.

Rosenthal, R. (1991) Meta-analytic procedures for social research (revised). Newbury Park: CA: Sage. p. 14-19. ISBN 9780803942462.

Sasse FH, Frohlich RL, Green RD et al. (1978) Arc and Oxygen Cutting. In Kearns WH, editor. Welding Handbook Volume 2: Welding Processes - Arc and Gas Welding and Cutting, Brazing, and Soldering. Miami, FL: American Welding Society. p. 459-516. ISBN 0-87171-148-6.

Schaumlöffel D. (2012) Nickel species: Analysis and toxic effects. J Trace Elem Med Bio; 26: 16.

Schulte P, Geraci C, Zumwalde R et al. (2008) Occupational risk management of engineered nanoparticles. J Occup Environ Hyg; 5: 239-249.

Shaffer RE, Rengasamy S. (2009) Respiratory protection against airborne nanoparticles: a review. J Nanopart Res; 11: 1661-1672. 
Shimadzu Corporation. (2016) Particle size distribution dependent on principle of measurement. Available from: URL: http://www.shimadzu.com/an/powder/support/practice/p01/lesson02.html (accessed 31 August 2016)

Sriram K, Lin GX, Jefferson AM et al. (2012) Manganese accumulation in nail clippings as a biomarker of welding fume exposure and neurotoxicity. Toxicology; 291: 73-82.

Sriram K, Lin GX, Jefferson AM et al. (2015) Modifying welding process parameters can reduce the neurotoxic potential of manganese-containing welding fumes. Toxicology; 328: 168-178.

Steyn HS, Ellis SM. (2009) Estimating an effect size in one-way multivariate analysis of variance (MANOVA). Multivariate Behav Res; 44: 106-129.

Tian L, Inthavong K, Lidén G et al. (2016) Transport and deposition of welding fume agglomerates in a realistic human nasal airway. Ann Occup Hyg; 60: 731-747.

Tokar EJ, Boyd WA, Freedman JH, Waalkes MP. (2013) Toxic Effects of Metals. In Klaassen CD, editor. Casarett \& Doull's Toxicology: The Basic Science of Poison. China: McGraw-Hill. p. 9811030. ISBN 978-0-07-176923-5.

Wilson WE, Chow JC, Claiborn C et al. (2002) Monitoring of particulate matter outdoors. Chemosphere; 49: 1009-1043.

Wittczak T, Walusiak J, Palczyński C. (2009) Welding-related respiratory diseases. Med Pr; 60: 201-208.

World Health Organization (WHO). (2016) Mercury and health. Available from: URL: http://www.who.int/mediacentre/factsheets/fs361/en/ (accessed 19 July 2016)

Zeidler-Erdely PC, Erdely A, Antonini JM. (2012) Immunotoxicology of arc welding fume: Employee and experimental animal studies. J Immunotoxicol; 9: 411-425. 
CHAPTER 4: CASE STUDY

Fumes released during gouging and lancing on various metal workpieces: A case study

MARELÉ KEYTER ${ }^{1}$, ALICIA VAN DER MERWE¹, ANJA FRANKEN¹

${ }^{1}$ Occupational Hygiene and Health Research Initiative (OHHRI), Faculty of Health Sciences, North-West University, Potchefstroom Campus, Private Bag X6001, Potchefstroom 2520, South Africa.

\section{Corresponding Author}

Ms A van der Merwe

Occupational Hygiene and Health Research Initiative (OHHRI)

Faculty of Health Sciences, North-West University, Potchefstroom Campus

Private Bag X6001

Potchefstroom

2520

South Africa

Tel: 0182991984

Fax: 0182991053

Email: alicia.vandermerwe@nwu.ac.za

Word count: 2999

Keywords: nanoparticles; particle size fractions; mining maintenance work; base metal. 


\subsection{Abstract}

Gouging and lancing on various metal workpieces during mining maintenance operations liberate fumes of unknown particle sizes and composition. Inhalation of such a "metal fume mixture" may lead to adverse health effects.

Objectives: A field study was conducted to determine the particle size fractions, including nanoparticles, and fume composition emitted during gouging and lancing on six metal workpieces. This case study also aimed to confirm that the composition of the base metal gouged or lanced influenced the metal fumes as well as the particle size fractions emitted.

Methods: Randomised side-by-side area samples of metalwork fumes liberated during gouging and lancing cutting processes were collected. These processes form part of maintenance work and was conducted on six metal workpieces at a South African mine. Samplers included the IOM sampler (inhalable fraction), a GK2.69 cyclone (thoracic fraction), an aluminium cyclone (respirable fraction), a NRD sampler (nano-size fraction) and an open-face filter cassette (particle size distribution). Metal workpieces included two backhoe shovels, a face shovel bucket, a head nut, a crusher liner and an axle liner.

Results: The backhoe shovel 2 had the widest range of ambient workplace concentration levels in all four particle size fractions. In the nano-size fraction, the head nut had the highest mean ambient concentration level $\left(2.46 \mathrm{mg} / \mathrm{m}^{3}\right)$ and backhoe shovel 2 the lowest $\left(1.74 \mathrm{mg} / \mathrm{m}^{3}\right)$. A total of 26 metals were present in the various particle size fractions and included aluminium, antimony, arsenic, chromium, cobalt, iron, lead, manganese, mercury, nickel, silver, tin and zinc. Fumes emitted from backhoe shovel 1 , the crusher liner and the axle liner contained the smallest particles with averages of $40.3 \mathrm{~nm}, 28.5 \mathrm{~nm}$ and $36.1 \mathrm{~nm}$, respectively.

Conclusions: Nanoparticles were present in the ambient particulate matter emitted from all six metal workpieces during gouging and lancing maintenance work. The findings of this study indicates that maintenance workers are exposed to various metals in all of the particle size fractions, which may guide the mine to implement control measures to protect their workers' health. It can be concluded that the composition of the base metal and the type of metalwork being done (gouging or lancing) determines the particle sizes and metal fumes emitted during these processes. 


\subsection{Introduction}

Fumes are generated during welding and thermal metal cutting processes and formation thereof takes place when vaporised materials condense in cool air (Plog, 2002; Pickford and Davies, 2007). These processes give rise to very fine solid particles of sizes usually smaller than $1 \mu \mathrm{m}$ in diameter which may agglomerate to form bigger clusters of particles (Plog, 2002; Zeidler-Erdely et al., 2012; Hariri et al., 2014).

Metal cutting is a process that is closely associated with welding processes and can be performed by means of gouging or lancing (Lyndon and Platcow; 2011). Gouging is used to prepare the weld groove or to remove defective welding zones and is done by melting the base metal (metal that is gouged or lanced) with an electric arc and the subsequent removal of the molten metal through a jet of compressed air. Lancing severs or removes metal by the chemical reaction of pure oxygen with a base metal (Sasse et al., 1978; Lyndon and Platcow; 2011).

Metal cutting methods are utilised during maintenance at the mine on various metal workpieces such as backhoe shovels, liners, face shovel buckets and head nuts (Lyndon and Platcow; 2011). Gouging is performed on a daily basis however, lancing is only performed over two days every six weeks during maintenance. For the purpose of this case study, the term 'metal workpieces' is used to describe the metal parts of mining equipment on which maintenance work was performed, since metalworking is defined as an operation in which work is performed on metals to generate individual parts or assemblies (U.S. Government Publishing Office; 2014). Gouging and lancing may be performed on backhoe shovels, face shovel buckets, head nuts, crusher liners, axle liners and various other metal workpieces. A backhoe shovel is a digging bucket used for excavating, a face shovel bucket is used for excavating and the moving of earth and a head nut is used to fasten wheels and liners (Holmes, 2000; Department of Science and Technology, 2012). Crusher and axle liners, when used together, are known as a gyratory crusher and is used to crush ore (OZZ Foundries, 2013; Titus Steel, 2015).

Backhoe shovels and face shovel buckets may contain chromium, cobalt, copper, iron, manganese, molybdenum, nickel, titanium and various other filler metals used as alloys (Holmes, 2000). Head nuts may contain chromium, copper, iron, manganese, molybdenum, nickel and various additives in the form of alloys (Department of Science and Technology, 2012). Crusher liners and axle liners may contain chromium, manganese, molybdenum, nickel, titanium as well as a variety of alloys (OZZ Foundries, 2013; Titus Steel, 2015). The metal composition of the metal workpieces gouged or lanced on may determine the metal fumes that will be emitted and the particle size fractions will be determined by the method used as well as the particles released from the weld pool (pool of molten metal) (Tian et al., 2016). 
Metal fumes from gouging and lancing processes, which comprise a complex mixture of various toxic metals, can cause adverse health effects through the inhalation thereof into the respiratory tract (Hartmann et al., 2014; Persoons et al., 2014; Sriram et al., 2015). The region of deposition in the respiratory tract is determined by the particle's physical and chemical characteristics (Schaumlöffel, 2012; Hartmann et al., 2014). Particle size fractions that are biologically relevant in the occupational health community can be divided into three groups, namely inhalable $(<100 \mu \mathrm{m})$, thoracic $(<10 \mu \mathrm{m})$ and respirable $(<4 \mu \mathrm{m})$ fractions based on the difference in their aerodynamic diameter (Cherrie and Aitken, 1999; Notø et al., 2016). Characterising particle size fractions present in the metal cutting fumes is important for determining the presence of respirable- and nanoparticles as these particles have the ability to penetrate to the deepest structures of the lungs and lead to health effects (Cherrie and Aitken, 1999; Pickford and Davies, 2007; Kang et al., 2011; Lehman-McKeeman, 2013).

The respirable fraction also includes nanoparticles that are in the submicron range and are measured in nanometres (nm) (Oberdörster et al., 2005; Oberdörster et al., 2013). Nanoparticles could potentially cause more toxic responses than particles that are larger in size because of their ability to move through the respiratory system and be absorbed into the blood circulation or deagglomerate in the lung fluid, where they will move through the body to target organs from where they will elicit toxic effects in other regions of the body (Kang et al., 2011; Lehman-McKeeman, 2013; Nilsson et al., 2013). These particles have a large surface area per unit volume, which makes them highly reactive (e.g., as a catalyst) and increases their toxicological activity (Kang et al., 2011; Chang et al., 2013; Tokar et al., 2013).

The different metals present in the base metal may influence the composition of the fumes emitted during gouging and lancing. This case study aimed to provide insight into metal fumes that are emitted during maintenance through metal cutting methods on different metal workpieces, with specific interest in the particle size fraction and metal composition thereof. This case study aimed to confirm that the composition of the base metal gouged or lanced influenced the metal fumes as well as the particle size fractions emitted.

\subsection{Methodology}

Area samples were collected during gouging and lancing metalworking were performed on six metal workpieces.

Inhalable, thoracic, respirable and nano-size particles were collected by means of a randomised, side-by-side sampling stand. Sample collection took place in two workshops (gouging) and one workshop (lancing), respectively. Samplers were mounted at a minimum height of $1.3 \mathrm{~m}$ and a maximum height of $1.7 \mathrm{~m}$ which is representative of the height of workers standing up using a 
sampling station (Khattab and Levetin, 2008). Samplers were spaced out to ensure that they do not influence each other, and mounted on a sampling stand in a random fashion with the aid of Latin square randomisation (PennState Eberly College of Science, 2016). The sampling equipment used during this sampling process is indicated in Table 1.

Table 1: Samplers used.

\begin{tabular}{|c|c|c|c|}
\hline Sampler & Particle size fraction & Flow rate & Filter used \\
\hline $\begin{array}{c}\text { IOM (Institute of Occupational Medicine) } \\
\text { sampler }\end{array}$ & Inhalable fraction & $2.0 \mathrm{l} / \mathrm{min}$ & $\begin{array}{l}\text { MCE* filter, } 25 \mathrm{~mm} \text {, } \\
\text { pore size of } 0.8 \mu \mathrm{m} \text {. }\end{array}$ \\
\hline GK2.69 cyclone sampler & Thoracic fraction & $1.6 \mathrm{l} / \mathrm{min}$ & $\begin{array}{l}\text { MCE filter, } 37 \mathrm{~mm} \text {, } \\
\text { pore size of } 0.8 \mu \mathrm{m} \text {. }\end{array}$ \\
\hline Aluminium respirable cyclone sampler & Respirable fraction & $2.5 \mathrm{l} / \mathrm{min}$ & $\begin{array}{l}\text { MCE filter, } 37 \mathrm{~mm} \text {, } \\
\text { pore size of } 0.8 \mu \mathrm{m} \text {. }\end{array}$ \\
\hline $\begin{array}{l}\text { NRD (Nanoparticle Respiratory } \\
\text { Deposition) sampler }\end{array}$ & Nano-sized fraction & $2.5 \mathrm{l} / \mathrm{min}$ & $\begin{array}{l}\text { Nylon filters, } 25 \mathrm{~mm} \text {, } \\
\text { pore size of } 11 \mu \mathrm{m} .\end{array}$ \\
\hline Open-faced filter cassette & $\begin{array}{l}\text { Particle size distribution } \\
\text { range }\end{array}$ & $2.0 \mathrm{l} / \mathrm{min}$ & $\begin{array}{l}\text { MCE filter, } 37 \mathrm{~mm} \text {, } \\
\text { pore size of } 0.8 \mu \mathrm{m} \text {. }\end{array}$ \\
\hline
\end{tabular}

${ }^{*}$ MCE - Mixed cellulose ester

Sampling pumps were calibrated at the respective flow rates of the different samplers by means of a Sensidyne Gilian Gilibrator-2 (Calibration date: July 2015), in line with the particle size fraction specific sampler. Pump calibration took place on site prior to the sampling and was verified after the sampling.

Samples were collected for each fraction size at the following six metal workpieces: two backhoe shovels, a face shovel bucket, a head nut, a crusher liner and an axle liner. Sample collection took place in the worst case scenario area (down-wind) which was pre-determined using smoke tubes. The samples were collected $2 \mathrm{~m}$ from the source and over a period of $45 \mathrm{~min}-108 \mathrm{~min}$ for gouging and at a range of between 5 and $10 \mathrm{~m}$ from the source and over a period of 75 min - 85 min for lancing, depending on the type of work and space availability.

Open-faced $37 \mathrm{~mm}$ filter cassettes were also used to collect total inhalable particles in the worst case scenario area. These samples were analysed for the size distribution range of the particles. One sample was collected per day in each workshop; therefore, a total of eight samples were collected for this purpose. 


\section{Analysis of samples}

The pre- and post-weight of filters were used to determine the particulate mass concentration of the inhalable, thoracic, respirable and nanometre fractions that were present during gouging and lancing operations. These samples were sent for gravimetric analysis (Method: NIOSH 0500 and MDHS 14/3) as well as metal elements scan analysis (Method: OSHA ID125G \& NIOSH 7300) to determine the total mass of inhalable, thoracic, respirable and nanometre particles and the metal composition of the particles respectively. An ICP-AES was used to determine the metal elements present in the fumes. Analyses were done by a SANAS accredited laboratory.

The eight samples that were collected using the open-faced $37 \mathrm{~mm}$ filter cassette were analysed to determine the particle size distribution range of all the collected particles. These samples were analysed by means of a Particle Size Analyser (Dynamic Light Scattering using a Horiba LB 550).

\section{Data analysis}

Descriptive statistics were utilised, namely mean, minimum and maximum. Microsoft Excel and GraphPad Prism 5 were used.

\section{Ethical considerations}

Static area monitoring was decided upon due to various reasons. It is unpractical and challenging to equip five personal sampling trains to a single worker. However, the main reason was to limit variation in personal sampling due to factors that cannot be controlled by the researcher. The aim was to determine particle size fractions and composition of the liberated fumes and not to compare concentrations against exposure limits in an attempt to evaluate worker exposure. Ethical approval was not required for this study since personal sampling was not conducted.

\subsection{Results}

The particulate mass concentration, metal composition and particle size distribution were determined for six metal workpieces being gouged or lanced.

Figure 1 presents the average, minimum and maximum concentration values (in $\mathrm{mg} / \mathrm{m}^{3}$ ), as measured by means of gravimetrical weighing of filters, of each fraction emitted during gouging on two backhoe shovels and a head nut and during lancing on a crusher liner and an axle liner. Backhoe shovel 2 indicated the greatest variation in all four fractions. Backhoe shovel 1 and 2 had the highest mean ambient workplace concentration levels in the inhalable, thoracic and respirable fractions and the head nut had the highest mean ambient workplace concentration levels in the nano-size fraction. 

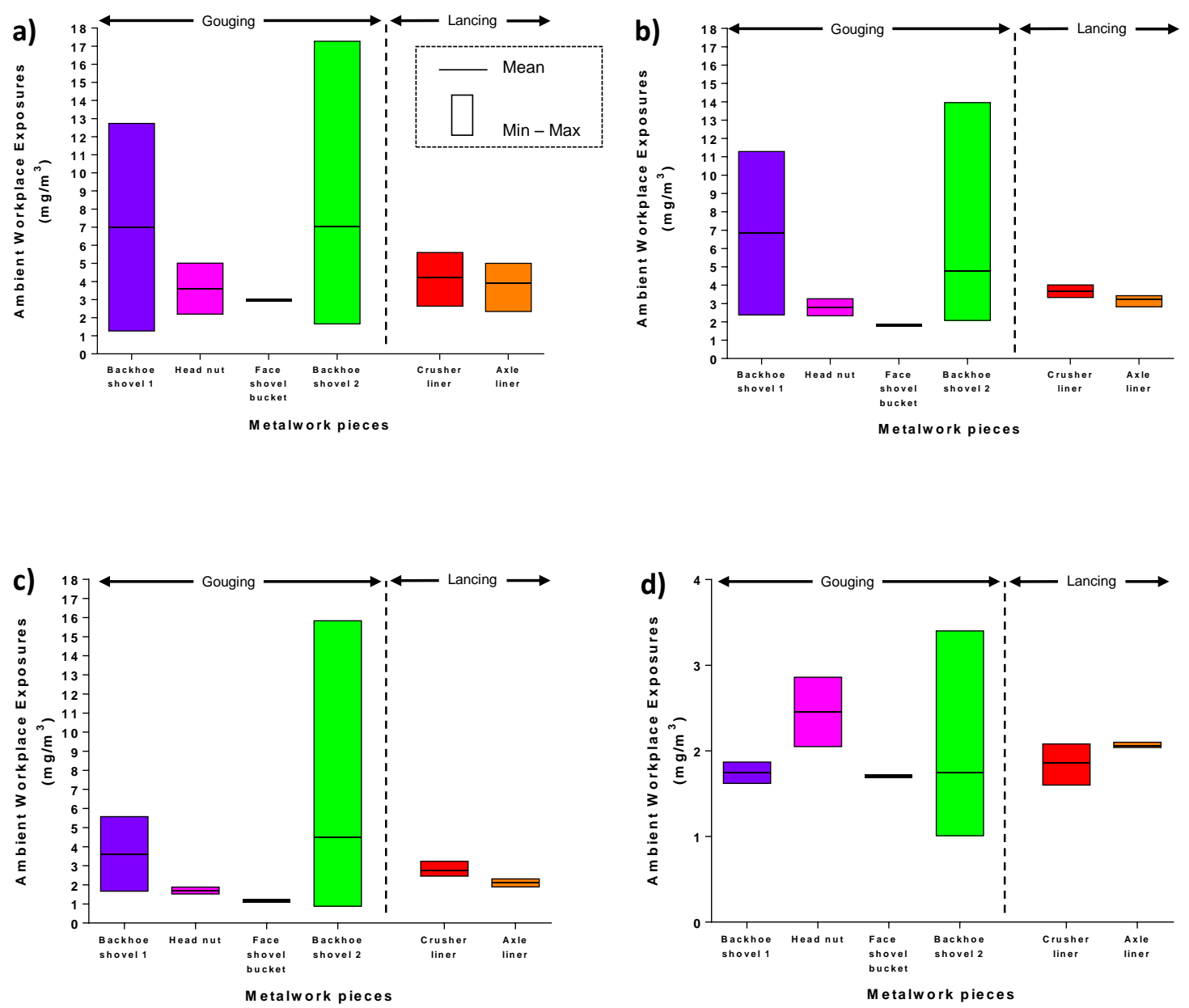

Figure 1: Ambient workplace concentration levels of the (a) inhalable fraction, (b) thoracic fraction, (c) respirable fraction and (d) nano-size fraction emitted during work on various metal workpieces.

The face shovel bucket shows a line in Figure 1, as only one sample was collected for each of the fractions.

Figure 2 indicates the various metals present in the metal workpieces that were gouged or lanced. A total of 26 metals were present. Twelve metals were present in all six of the metal workpieces: $\mathrm{Al}, \mathrm{Ca}, \mathrm{Cr}, \mathrm{Cu}, \mathrm{Fe}, \mathrm{Mg}, \mathrm{Mn}, \mathrm{Ni}, \mathrm{Na}, \mathrm{Sn}, \mathrm{Ti}$ and $\mathrm{Zn}$ (indicated in bold in Figure 4.2). Mercury was only present in the axle liner samples. Arsenic was found in backhoe shovel 2, the crusher liner and the axle liner. Cobalt was present in all of the metal workpieces, except for the head nut and the face shovel bucket, while lead was found in all of the metal workpieces, except the face shovel bucket. 


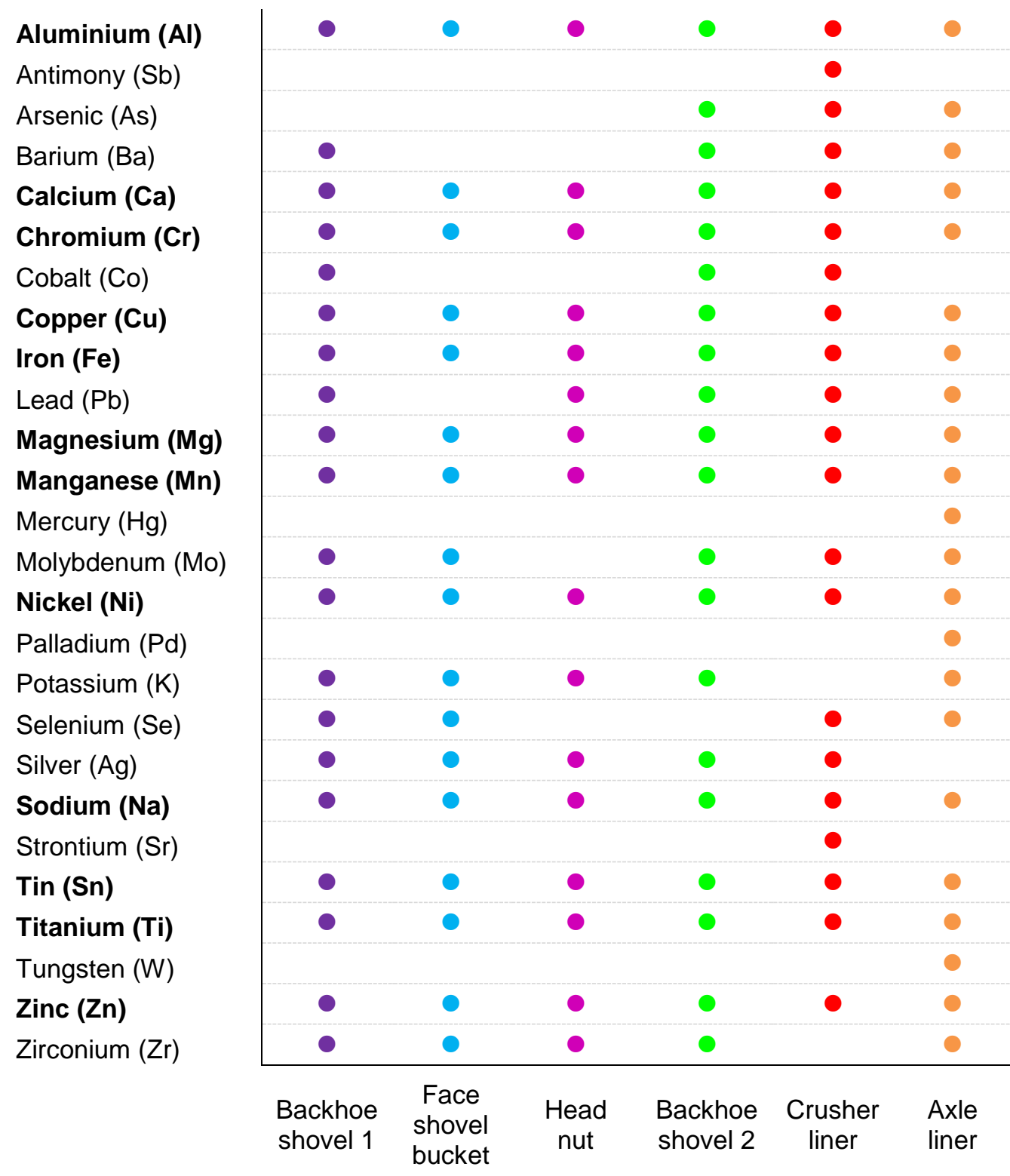

Figure 2: $\quad$ Figure showing metals present in fumes emitted during work on various metal workpieces. (Metals in bold were present in fumes emitted from all six metal workpieces)

Figure 3 indicates the particle size distribution (in $\mathrm{nm}$ ) of the fumes emitted from the six metal workpieces that were gouged or lanced. Particle size distribution is used as an index (in the form of a figure or table) to depict the frequency in percentage of particles present in various particle size intervals (Shimadzu Corporation, 2016). For example, backhoe shovel 1 showed a large amount of particles in a small range and backhoe shovel 2 showed particles in a wide range of sizes. Particles emitted from backhoe shovel 2 were in the range of $22.50-2268.7 \mathrm{~nm}$, whereas $20.8 \%$ of the particles emitted from backhoe shovel 1 were approximately $44.3 \mathrm{~nm}$. 
25.00

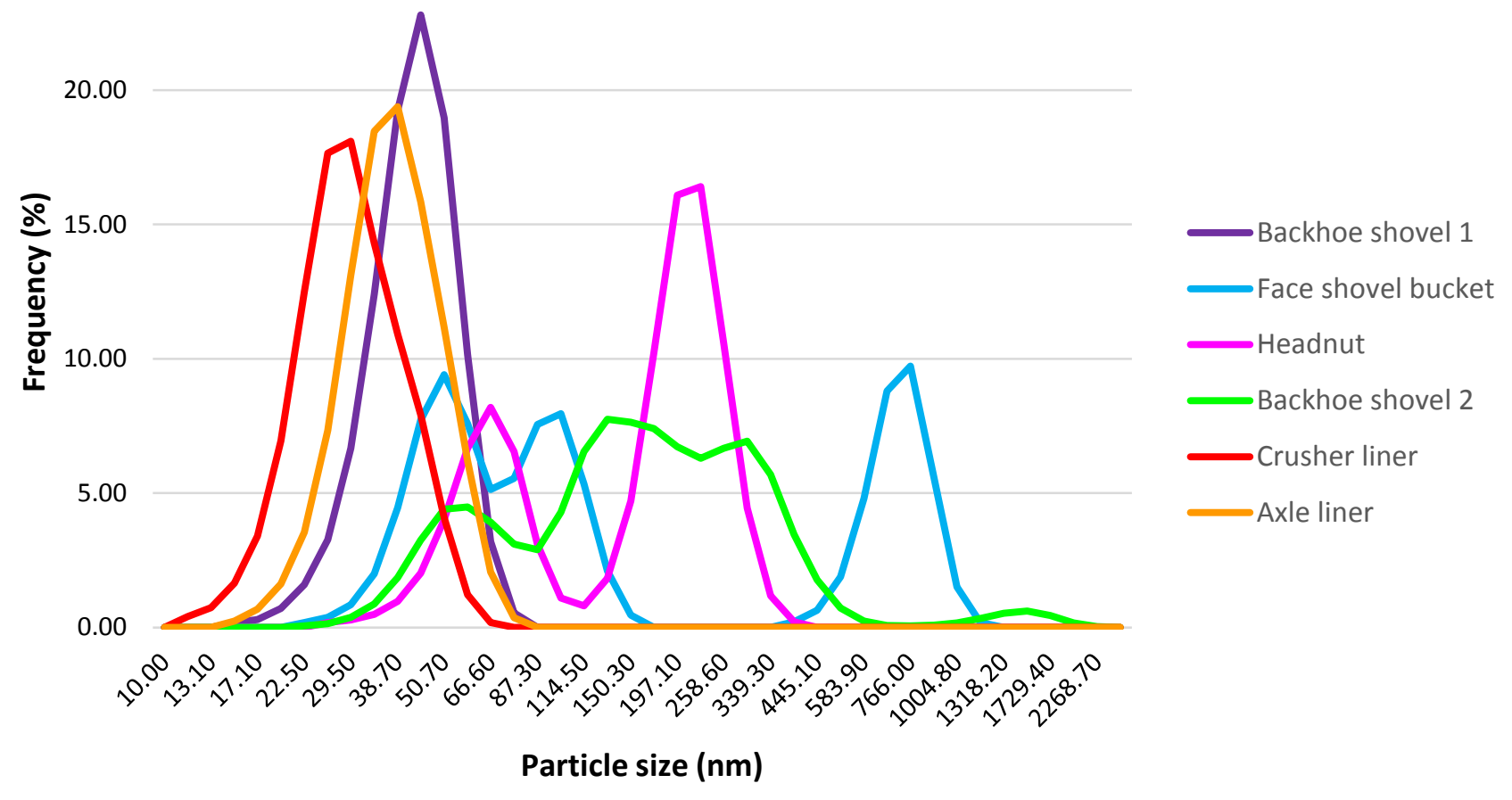

Figure 3: Particle size distribution of fumes emitted from various metal workpieces.

\subsection{Discussion}

This study was specifically conducted on various metal workpieces to determine particle size and metal composition of airborne particulate matter present in metal fumes emitted during maintenance work to confirm if the base metals of the metal workpieces being gouged or lanced influence the fumes liberated. This study is unique, since it focusses on various metal workpieces and not on processes.

The results from the gravimetric analysis of the collected samples suggested the presence of inhalable, thoracic, respirable and nano-size fractions emitted from each of the six of the metal workpieces that were gouged and lanced.

Nanoparticles were generated during maintenance work on all six metal workpieces that were released into the work environment, potentially exposing maintenance workers as well as other employees working in the immediate vicinity to these particles. Nanoparticles can migrate to the alveolar region of the lungs and be absorbed into the blood, and can therefore be transported throughout the body, eliciting toxic effects at other target organs and regions of the body (Kang et al., 2011; Lehman-McKeeman, 2013). These particles are highly reactive and have a large surface area per unit volume and this makes them unique to larger particles (Kang et al., 2011; Chang et al., 2013). The clearance of nanoparticles from the lungs is also poor as these particles are too small to be recognised and phagocytised by alveolar macrophages 
(Oberdörster et al., 2013). These unique characteristics may be deemed as challenging when addressing the potential health effects and impact of nanoparticles, since the health effects caused by nano-size metals are still unknown.

Nanoparticles may remain airborne for longer periods of time than larger particles and will follow the surrounding airflow in a workshop. Therefore, they can be controlled using local exhaust ventilation systems (Schulte et al., 2008). Supplemental use of personal protective equipment (PPE) is important, since the health risk profiles of nanoparticles are still undefined (Schulte et al., 2008). This PPE may include shoes made of low permeability material, trousers without turn-ups, clothes made out of woven fibres and $\mathrm{NIOSH}$-certified air-purifying respirators with P100 filtering media (Rengasamy et al., 2008; Shaffer and Rengasamy, 2009; Del Castillo, 2013).

The gouging and lancing of various metal workpieces will give rise to fumes with an unknown metal composition. This case study showed the following metals as indicated in Figure 2 in the metal fumes emitted during maintenance work on various metal workpieces. Aluminium particles in the nano-size fraction were found in both backhoe shovels, the crusher and axle liners. Aluminium is classified as a Group 1 carcinogen (IARC, 2012b). Arsenic and mercury were only found in the axle liner in the nano-size fraction and are both carcinogenic (Group 1 and Group 2B (methyl mercury compounds), respectively (IARC, 1993; IARC, 2012a). Metallic mercury is classified as a Group 3 carcinogen (IARC, 1993). Group 3 carcinogens are "not classifiable as to its carcinogenicity to humans", however the metals that fall within this group cannot be excluded since it cannot be ruled out that these metals may cause cancer (IARC, 2016). All of the metal workpieces, except the face shovel bucket, contained chromium in the nano-size fraction and is also classified as a Group 1 carcinogen (hexavalent chromium) and Group 3 carcinogen (trivalent chromium) (IARC, 2012a). Iron and manganese were present in the nano-size fraction in all of the metal workpieces. Iron is a known human carcinogen (Group 1 carcinogen) and manganese may lead to the development of bronchitis, pneumonitis, asthma, a decrease in lung function and manganism (a neurological disorder similar to Parkinson's disease) (IARC, 2012b; Tokar et al., 2013; Sriram et al., 2015). Manganism affects dopamine release from dopaminergic neurons and may cause bradykinesia (slow movements), rigidity, behavioural changes, emotional instability, memory loss, speech disturbances, dystonia, muscle cramps and a decrease in muscle movement (Berardelli et al., 2001; Antonini et al., 2006; Tokar et al., 2013). Lead is also classified as a carcinogen (Group 2A) and was found in backhoe shovel 1, the head nut, the crusher and axle liners (IARC, 2006). Lead exposure may lead to the development of peripheral neuropathy, encephalopathy and hypertension, may influence the reproductive systems in both males and females and is stored in the body, leading to accumulation (IARC, 2006; ATSDR, 2010; Tokar et al., 2013). Nickel, a Type IV skin sensitiser as well as a Group 1 and 2B carcinogen (nickel compounds and metallic nickel), was present in the nano-size fraction of both backhoe 
shovels, the face shovel bucket and the crusher liner (IARC, 2012a). Tin nanoparticles were found in the head nut, axle liner and both backhoe shovels and may lead to the development of stannosis (a benign non-fibrotic pneumoconiosis), pulmonary fibrosis, pulmonary changes and neurological problems (Liu et al., 2012; Tokar et al., 2013). Backhoe shovel 1 and the head nut contained zinc nanoparticles, which may lead to lung fibrosis, pneumonitis, occupational asthma, damage to the mucous membranes and metal fume fever (Tokar et al., 2013). The metal workpieces gouged or lanced could be ranked from most hazardous to less hazardous, based on maximum concentrations sampled, as follows: backhoe shovel 2, gouging > backhoe shovel 1, gouging > crusher liner, lancing $>$ head nut, gouging $>$ axle liner, lancing $>$ face shovel bucket, gouging.

\subsection{Conclusions}

This study provided a specific understanding of the ambient workplace concentration levels by focusing on six metal workpieces during maintenance work with specific reference to different particle size fractions and metal composition of fumes emitted. No prior knowledge existed concerning the particle size fractions (especially the nano-size fraction) present or the metal composition of these metal workpieces, during gouging and lancing maintenance work. Supervisors, managers and workers did not have any knowledge of the metal composition of the metal workpieces being gouged or lanced.

This study is novel by indicating the presence of nanoparticles (submicron particles) in the ambient particulate matter emitted from all six metal workpieces. The metal composition of the fumes emitted from the metal workpieces by gouging and lancing plays a role of great importance in the toxicological effects on the maintenance workers as these metals may accumulate in the body and cause various health effects in different regions of the body. This information may assist the mine to take the base metals worked on into account during risk assessments and to implement control measures to protect their workers' health, such as local exhaust ventilation, reduction of work periods or rotation of workers and specific PPE for nanoparticle exposure. From the results, it can be concluded that the composition of the base metal being gouged or lanced will definitely influence the particle sizes and metal fumes that will be emitted during these processes.

\section{Acknowledgements}

This study was funded by a world class mining group. 


\subsection{References}

Agency for Toxic Substances and Disease Registry (ATSDR). (2010) Lead toxicity. Available from: URL: http://www.atsdr.cdc.gov/csem/csem.asp?csem=7\&po=10 (accessed 18 July 2016)

Antonini JM, Santamaria AB, Jenkins NT et al. (2006) Fate of manganese associated with the inhalation of welding fumes: Potential neurological effects. Neurotoxicol; 27: 304-310.

Berardelli A, Rothwell JC, Thompson PD, Hallet M. (2001) Pathophysiology of bradykinesia in Parkinson's disease. Brain; 124: 2131-2146.

Chang C, Demokritou P, Shafer M, Christiani D. (2013) Physicochemical and toxicological characteristics of welding fume derived particles generated from real time welding processes. Environ Sci - Proc Imp; 15: 214-224.

Cherrie JW, Aitken RJ. (1999) Measurement of human exposure to biologically relevant fractions of the total aerosol. Occup Environ Med; 56: 747-752.

Del Castillo AM. (2013) Nanomaterials and workplace health \& safety: What are the issues for workers? Brussels: European Trade Union Institute. p. 23-24. ISBN 978-2-87452-288-8.

Department of Science and Technology, India. (2012) M.S. and high tensile nuts and bolts. Available from: URL: http://www.techno-preneur.net/technology/projectprofiles/mechanics/bolts.html (accessed 25 July 2016)

Hariri A, Azreen N, Abdull N et al. (2014) Determination of customer requirement for welding fumes index development in automotive industries by using quality function deployment approach. Int J Automot Mech Eng; 9: 1609-1619.

Hartmann L, Bauer M, Bertram J et al. (2014) Assessment of the biological effects of welding fumes emitted from metal inert gas welding processes of aluminium and zinc-plated materials in humans. Int J Hyg Envir Health; 217: 160-168.

Holmes GS. (2000) How products are made: Backhoe. Available from: URL: http://www.madehow.com/Volume-6/Backhoe.html (accessed 25 July 2016)

IARC (International Agency for Research on Cancer). (1993) Monographs on the evaluation of carcinogenic risks to humans (Volume 58): Beryllium, cadmium, mercury and exposures in the glass manufacturing industry. Available from: URL: https://monographs.iarc.fr/ENG/Monographs/vol58/mono58.pdf (accessed 16 June 2016) 
IARC (International Agency for Research on Cancer). (2006) Monographs on the evaluation of carcinogenic risks to humans (Volume 87): Inorganic and Organic Lead Compounds. Available from: URL: http://monographs.iarc.fr/ENG/Monographs/vol87/mono87.pdf (accessed 10 May 2015)

IARC (International Agency for Research on Cancer). (2012a) Monographs on the evaluation of carcinogenic risks to humans (Volume 100C): Arsenic, metals, fibres, and dusts. Available from: URL: http://monographs.iarc.fr/ENG/Monographs/vol100C/mono100C.pdf (accessed 10 May 2015)

IARC (International Agency for Research on Cancer). (2012b) Monographs on the evaluation of carcinogenic risks to humans (Volume 100F): Chemical agents and related occupations. Available from: URL: http://monographs.iarc.fr/ENG/Monographs/vol100F/mono100F.pdf (accessed 10 May 2015)

IARC (International Agency for Research on Cancer). (2016) Agents classified by the IARC Monographs, volumes 1-115. Available from: URL: http://monographs.iarc.fr/ENG/Classification/ (accessed 10 May 2015)

Kang GS, Gillespie PA, Gunnison A et al. (2011) Long-term inhalation exposure to nickel nanoparticles exacerbated atherosclerosis in a susceptible mouse model. Environ Health Persp; 119: 176-181.

Khattab A, Levetin E. (2008) Effect of sampling height on the concentration of airborne fungal spores. Ann Allergy Ashtma Immunol; 101: 529-534.

Lehman-McKeeman LD. (2013) Absorption, distribution and excretion of toxicants. In Klaassen CD, editor. Casarett \& Doull's Toxicology: The Basic Science of Poison. China: McGraw-Hill. p. 153-183. ISBN 978-0-07-176923-5.

Liu HH, Chen CY, Chen Gl et al. (2012) Relationship between indium exposure and oxidative damage in workers in indium tin oxide production plants. Int Arch Occup Environ Health; 85: 447453.

Lyndon GS, Platcow PA. (2011) Welding and Thermal Cutting. Available from: URL: http://www.ilo.org/iloenc/part-xiii/metal-processing-and-metal-working-industry/metalprocessing-and-metal-working/item/676-welding-and-thermal-cutting (accessed 6 July 2015)

Nilsson PT, Isaxon C, Eriksson AC et al. (2013) Nano-objects emitted during maintenance of common particle generators: direct chemical characterization with aerosol mass spectrometry and implications for risk assessments. J Nanopart Res; 15: 1-16. 
Notø HP, Nordby KC, Eduard W. (2016) Relationships between personal measurements of 'total' dust, respirable, thoracic, and inhalable aerosol fractions in the cement production industry. Ann Occup Hyg; 60: 453-466.

Oberdörster G, Kane AB, Klaper RD, Hurt RH. (2013) Nanotoxicology. In Klaassen CD, editor. Casarett \& Doull's Toxicology: The Basic Science of Poison. China: McGraw-Hill. p. 1189-1229. ISBN 978-0-07-176923-5.

Oberdörster G, Oberdörster E, Oberdörster J. (2005) Nanotoxicology: An Emerging Discipline Evolving from Studies of Ultrafine Particles. Environ Health Persp; 113: 823-839.

OZZ Foundries. (2013) Material Specifications Catalogue. Available from: URL: http://www.crushingequip.com.au/products/pdf/OZZ-Material\%20Specifications.pdf (accessed 26 July 2016)

PennState Eberly College of Science. (2016) The Latin Square Design. Available from: URL: https://onlinecourses.science.psu.edu/stat503/node/21 (accessed 4 April 2016)

Persoons R, Arnoux D, Monssu T et al. (2014) Determinants of occupational exposure to metals by gas metal arc welding and risk management measures: A bio monitoring study. Toxicol Lett; 231: 135-141.

Pickford G, Davies B. (2007) Aerosols. In Tillman C, editor. Principles of Occupational Health \& Hygiene: An Introduction. Singapore: ANL Printers. p. 125-171. ISBN 9781741750584.

Plog BA. (2002) Overview of Industrial Hygiene. In Plog BA, Quinlan PJ, editors. Fundamentals of Industrial Hygiene. United States of America: National Safety Council. p. 3-32. ISBN 0-87912216-1.

Rengasamy S, King WP, Eimer BC, Shaffer RE. (2008) Filtering performance of NIOSH-approved N95 and P100 filtering facepiece respirators against 4 to 30 nanometer-size nanoparticles. J Occup Environ Hyg; 5: 556-564.

Sasse FH, Frohlich RL, Green RD et al. (1978) Arc and Oxygen Cutting. In Kearns WH, editor. Welding Handbook Volume 2: Welding Processes - Arc and Gas Welding and Cutting, Brazing, and Soldering. Miami, FL: American Welding Society. p. 459-516. ISBN 0-87171-148-6.

Schaumlöffel D. (2012) Nickel species: Analysis and toxic effects. J Trace Elem Med Bio; 26: 16. 
Schulte P, Geraci C, Zumwalde R et al. (2008) Occupational risk management of engineered nanoparticles. J Occup Environ Hyg; 5: 239-249.

Shaffer RE, Rengasamy S. (2009) Respiratory protection against airborne nanoparticles: a review. J Nanopart Res; 11: 1661-1672.

Shimadzu Corporation. (2016) Particle size distribution dependent on principle of measurement. Available from: URL: http://www.shimadzu.com/an/powder/support/practice/p01/lesson02.html (accessed 31 August 2016)

Sriram K, Lin GX, Jefferson AM et al. (2015) Modifying welding process parameters can reduce the neurotoxic potential of manganese-containing welding fumes. Toxicology; 328: 168-178.

Tian L, Inthavong K, Lidén G et al. (2016) Transport and deposition of welding fume agglomerates in a realistic human nasal airway. Ann Occup Hyg; 60: 731-747.

Titus Steel. (2015) Manganese Steel. Available from: URL: http://www.titussteel.com/ourproducts/wear-steel/manganese/ (accessed 26 July 2016)

Tokar EJ, Boyd WA, Freedman JH, Waalkes MP. (2013) Toxic Effects of Metals. In Klaassen CD, editor. Casarett \& Doull's Toxicology: The Basic Science of Poison. China: McGraw-Hill. p. 9811030. ISBN 978-0-07-176923-5.

U.S. Government Publishing Office. (2014) Title 7: Agriculture (Part 3201 - Guidelines for Designating Biobased Products for Federal Procurement). Available from: URL: http://www.ecfr.gov/cgi-

$\mathrm{bin} /$ retrieveECFR?gp=\&SID=0736d7b11 ec8e6d72bfe7e60c90c7101\&mc=true\& $=$ pt7.15.3201\& r=PART\&ty=HTML\#se7.15.3201_141 (accessed 8 September 2016)

Zeidler-Erdely PC, Erdely A, Antonini JM. (2012) Immunotoxicology of arc welding fume: Employee and experimental animal studies. J Immunotoxicol; 9: 411-425. 


\section{CHAPTER 5: CONCLUDING CHAPTER}

\subsection{Further discussion and final conclusion}

This study was requested by a mine in South Africa where gouging and lancing processes are performed on various metal workpieces. The particle size fractions as well as metal composition present in these fumes liberated during the above-mentioned processes were unknown and therefore, deemed the general aim of this study. With known particle size fractions and metal fume composition, informed decisions can be made with regard to the particle size fractions to be included in monitoring (either area or personal exposure monitoring) and possible control measures to be implemented.

Three maintenance workshops were selected as gouging and lancing processes were performed in these locations. In the mine's maintenance workshop, welding and metal cutting processes are performed at various workstations. This workshop has extraction fans that are situated in the roof and far from the source or activity. In the mining contractor's workshop, welding and metal cutting processes are also performed. This workshop has two large doors situated next to each other, with little mechanical ventilation systems. The secondary crusher workshop contains the secondary crusher, where ore is being crushed, and only lancing is performed in this open-plan workshop.

Characterising the particle size fractions present in metal fumes is of importance since exposure to the respirable (including the nano-size) fraction may increase the risk posed to workers in terms of particle deposition in the respiratory tract. It is critical to consider these fraction sizes since the particles may penetrate to the alveolar region and the deepest structures of the lungs, form where they may be absorbed into the blood circulation (Wilson et al., 2002; Pickford and Davies, 2007). In the blood circulation, these particles can migrate through the body and may elicit toxic effects in other regions of the body (Kang et al., 2011; Nilsson et al., 2013; Oberdörster et al., 2013). There is still little information regarding the toxicity of nanoparticles, as nanoparticles in the occupational hygiene setting has not been extensively researched and is a new field of research.

Characterising the composition of metal fumes liberated during gouging and lancing on various metal workpieces is also important since exposure to various metals may lead to various adverse health effects, including metal fume fever, bronchitis, pneumoconiosis, asthma, emphysema, neurological dysfunction and various types of cancer, to name just a few (Antonini, 2003; Wittczak et al., 2009; La Vecchia and Maestrelli, 2011; Persoons et al., 2014; Wardhana and Datau, 2014). 
In Chapter 3, the results indicated the presence of inhalable, thoracic, respirable and nano-size fractions in the fumes liberated during gouging and lancing processes. All four fractions had the highest mean ambient workplace concentration during gouging processes $\left(7.05 \mathrm{mg} / \mathrm{m}^{3}\right.$, $4.77 \mathrm{mg} / \mathrm{m}^{3}, 4.48 \mathrm{mg} / \mathrm{m}^{3}, 2.02 \mathrm{mg} / \mathrm{m}^{3}$, respectively). Lancing processes $(\bar{x}=32.3 \mathrm{~nm})$ emitted smaller mean particle sizes than gouging processes $(\bar{x}=171.8 \mathrm{~nm})$. Gouging fumes contain particles with a wide range of sizes, whereas lancing fumes contain a high frequency of particles in a small range and of smaller sizes. It is possible that ambient workplace concentration levels in the secondary crusher workshop, where lancing was performed, could have been influenced by the crusher that is situated in this workshop. The secondary crusher is actively crushing ore, which may emit ore dust into the environment. Therefore, the crusher may cause highly variable ambient concentration levels in the surrounding area, which may cause an additional exposure risk to workers.

A total of 26 metals were present in the various particle size fractions and included aluminium, arsenic, chromium, cobalt, iron, lead, manganese, mercury and nickel. The following metals were found in the respirable and nano-size fraction during gouging and lancing processes: calcium, chromium, copper, iron, magnesium, manganese, potassium, tin and titanium. Aluminium, molybdenum, nickel, sodium and zinc were also present in the respirable fraction liberated during gouging and lancing. Lancing also liberated arsenic and lead fumes in the respirable fraction and arsenic, lead, molybdenum and sodium in the nano-size fraction.

Chapter 4 indicated that all four fractions, including nanoparticles, were present in the fumes liberated during gouging and lancing on six specific metal workpieces. The backhoe shovels liberated the highest mean ambient workplace concentration levels in the inhalable, thoracic and respirable fractions and the head nut liberated the highest mean ambient workplace concentration levels in the nano-size fraction. The backhoe shovel 1, the crusher liner and the axle liner liberated smaller mean particle sizes and showed a high frequency of particles in a small range. The backhoe shovel 2, face shovel bucket and head nut liberated a wide range of particle sizes. Twelve metals were present in all six of the metal workpieces: aluminium, calcium, chromium, copper, iron, magnesium, manganese, nickel, sodium, tin, titanium and zinc. Mercury was only present in the axle liner samples. Arsenic was found in backhoe shovel 2, the crusher liner and the axle liner. Cobalt was present in all of the metal workpieces, except for the head nut and the face shovel bucket, while lead was found in all of the metal workpieces, except the face shovel bucket.

To summarise the results of Chapter 3 and 4; all four fraction sizes and a total of 26 metals were present in the fumes liberated during gouging and lancing of various metal workpieces. In general, lancing processes emitted smaller mean particle sizes than gouging processes, with the exception 
of the backhoe shovel 1. This could impact the workers in the occupational setting, since information on metals in the nano-size fraction is limited and the toxicity is unknown.

No prior knowledge existed concerning the particle size fractions (especially the nano-size fraction) present or the metal composition of the fumes emitted during gouging and lancing on these metal workpieces. Supervisors, managers and workers did not have any knowledge of the metal composition of the metal workpieces being gouged or lanced. This study provided this information and indicated that the exposure of workers to metal fumes and particle size fractions is determined by the metal workpiece being gouged or lanced, the type of metalwork being done (gouging or lancing) and the electrodes or rods used during the processes, since electrodes and rods comprise different materials and metals (Lehnert et al., 2012).

The findings of this study indicate that maintenance workers are exposed to various hazardous metals in all of the particle size fractions as well as nanoparticles. This study shows that the nanosize fraction and possibly the thoracic fraction should also be included during future personal or area exposure assessments and monitoring in addition to inhalable and respirable sampling. Exposure assessments should go beyond compliance by including these fractions, even when there are no OELs available, to protect the health of workers. Due to the lack of legislative standards for the thoracic and nano-size fraction, exposure to these particles size fractions, should be minimised. This information may assist the mine in implementing control measures as well as precautions to protect their workers' health such as ventilation systems (local exhaust ventilation), administrative controls (reduction of work periods and/or rotation of workers) and lastly, appropriate PPE. These are discussed in detail in Section 5.4.

This study consisted of two research questions. Literature indicates that metal fumes contain inhalable, thoracic and respirable particulate matter; however, little research has been done on the presence of the nano-sized particulate fraction in metal fumes (Vincent and Brosseau, 1995; Zeidler-Erdely et al., 2012; Hariri et al., 2014; Tashiro et al., 2015). Nanoparticles will cause stronger toxic responses than larger particles because of their ability to be absorbed from the lungs into the blood circulation and travel to target organs (Kang et al., 2011; Oberdörster et al., 2013; Peixe et al., 2015). Therefore, it raised the first research question: Are nanoparticles present in the metal fumes emitted from gouging and lancing methods? This study indicated that nanoparticles were liberated during both methods utilised on all six of the metal workpieces in all three maintenance workshops that were selected in this study. The study also indicated that workers utilising gouging and lancing processes on these metal workpieces may be potentially at risk with regard to the inhalable, thoracic and respirable fractions in addition to the nano-size fraction. To answer the first research question; nanoparticles were indeed present in fumes liberated during both gouging and lancing processes on various metal workpieces. 
The chemical composition of particles is also an important consideration as it will influence the toxicological profile of the fume. In addition to this, metal fume combinations may have and additive effect, which may result in adverse health effects (Hartmann et al., 2014; Sriram et al., 2015). Therefore, it raised the second research question: What is the metal composition of the fumes emitted from cutting methods (gouging and lancing) to which workers are exposed? This study showed 26 metals present in the fumes emitted during gouging and lancing on all six metal workpieces in all three maintenance workshops. Gouging on backhoe shovels, a face shovel bucket and a head nut liberated the following metals in the maintenance and the mining contractor's workshops: aluminium, arsenic, barium, calcium, chromium, cobalt, copper, iron, lead, magnesium, manganese, molybdenum, nickel, potassium, selenium, silver, sodium, tin, titanium, zinc and zirconium. Lancing on a crusher liner and an axle liner in the secondary crusher workshop liberated the same metals as gouging as well as the following unique metals: antimony, mercury, palladium, strontium and tungsten. Therefore, to answer the second research question; a total of 26 various metals were liberated during gouging and lancing processes on metal workpieces, with slight differences in metal composition between gouging and lancing, with potential serious health effects.

\subsection{Limitations of this study}

As nanoparticles in the occupational hygiene setting have not been extensively researched, literature regarding nanoparticle exposure is still very limited. There are currently no available OELs concerning nanoparticles due to the lack of knowledge relating to nanoparticle toxicology which may have hampered the updating of legislation. To determine OELs for nanoparticle exposure, various physicochemical factors should be considered and nanoparticle toxicology should be researched in depth (Schulte et al., 2008). Due to the lack of OELs for nanoparticles, worker exposure to these particles should be minimised by using control measures, such as mechanical ventilation and PPE (OSHA, 2013). Supplementary research should also be conducted to determine filter media effectiveness, respirator leakage and the effectiveness of clothing or gloves against nanoparticle exposure (Schulte et al., 2008).

The success of airborne particulate matter collection by samplers can be influenced by environmental factors such as changing wind directions. The changing wind directions may potentially influence the ability of some samplers to capture sufficient amounts of fumes and should be considered when sampling.

During this study, area samples were collected due to the difficulty to equip one employee with five different samplers as well as the variation in personal samples as a result of factors that cannot be controlled by the researcher, such as employees tampering with the sampling equipment. The aim of this project was also not to compare exposure with OELs as the particle 
size fraction and the metal composition of fumes could be determined using area samples. However, this leads to the inability to compare the measured exposure concentrations to OELs as well as the inability to determine compliance with legislation.

\subsection{Future studies}

As mentioned previously, area sampling was conducted in this study. For future studies, it would be ideal to conduct both area and personal sampling and to compare the two methods to determine if area sampling is a true representation of workers' exposure to metal fumes.

The IARC classifies various metals (aluminium, antimony, arsenic, chromium, cobalt, iron, lead, mercury and nickel) found in the fumes emitted during gouging and lancing as carcinogenic to humans (IARC, 1989; IARC, 1991; IARC, 1993; IARC, 2006a; IARC, 2006b; IARC, 2012a; IARC, 2012b). There are no safe OELs or limits for these metals and therefore, the mine should consider

specific control measures to protect workers against exposure to these potential carcinogenic metals.

In future studies, gouging and lancing could also be investigated in separate studies and more focus can be placed on the two processes. More samples could also be collected and each process could be investigated over a longer period of time, during different scenarios.

A study could also be done on the composition of metal workpieces that were gouged and lanced, to determine the composition of these pieces and fumes liberated, since the managers, supervisors and employees do not know what they are working on.

More extensive research may also be done on the GK2.69 cyclone as well as the NRD sampler and their applications in the occupational hygiene industry, to determine the efficiency of these samplers and if they can be incorporated into occupational hygiene monitoring programmes. 


\subsection{Recommendations}

\subsubsection{Engineering and administrative control measures}

\begin{tabular}{|c|c|}
\hline Observation & Recommendation \\
\hline $\begin{array}{l}\text { No mechanical ventilation system was } \\
\text { installed in the mining contractor's workshop } \\
\text { during the time of the study. Natural } \\
\text { ventilation was utilised by means of doors } \\
\text { which may not be sufficient. }\end{array}$ & $\begin{array}{l}\text { Consider a mechanical ventilation system, } \\
\text { local exhaust ventilation (LEV) or the use of } \\
\text { floor fans (dilution ventilation) to redirect } \\
\text { fumes away from the activity or source. } \\
\text { Ventilation should be such as not to form a } \\
\text { dead space (area were no airflow is present). }\end{array}$ \\
\hline $\begin{array}{l}\text { There are mechanical ventilation systems } \\
\text { installed in the maintenance workshop; } \\
\text { however, it may not be sufficient, since the } \\
\text { extraction fans are situated too far from the } \\
\text { activity or source. }\end{array}$ & $\begin{array}{l}\text { Floor fans could be used to redirect fumes } \\
\text { away from the activity or source. Ventilation } \\
\text { should be such as not to form a dead space } \\
\text { (area were no airflow is present). }\end{array}$ \\
\hline $\begin{array}{l}\text { Workers performing lancing processes on } \\
\text { the crusher liner create a semi-confined } \\
\text { space while working (see Photo 1). }\end{array}$ & $\begin{array}{l}\text { Engineering and administrative control } \\
\text { measures could be implemented to } \\
\text { decrease the risks of work in the confined } \\
\text { space, such as local extraction ventilation at } \\
\text { the source/activity, reduction of work } \\
\text { periods, rotation of workers and supervision } \\
\text { to ensure workers are wearing PPE and are } \\
\text { following the correct work procedures. }\end{array}$ \\
\hline $\begin{array}{l}\text { Picture 2: Worker creating a semi-confined space } \\
\text { while lancing. }\end{array}$ & $\begin{array}{l}\text { Picture 3: Example of local exhaust ventilation } \\
\text { system (DiscoveryBlog, 2016). }\end{array}$ \\
\hline
\end{tabular}




\begin{tabular}{|c|c|}
\hline $\begin{array}{l}\text { Supervisors and workers in the vicinity of the } \\
\text { gouging/lancing processes do not wear } \\
\text { respiratory protective equipment, although } \\
\text { they are also exposed to the fumes from } \\
\text { these processes. }\end{array}$ & $\begin{array}{l}\text { Engineering and administrative control } \\
\text { measures could be implemented to } \\
\text { decrease the risk of exposure, such as floor } \\
\text { fans, standing in a different area, intermittent } \\
\text { check-ups on workers to ensure correct use } \\
\text { of PPE, wearing PPE and RPE (such as air } \\
\text { purifying respirators). Areas should be } \\
\text { demarcated as respirator zones and no } \\
\text { person may be allowed to enter a } \\
\text { demarcated area without appropriate } \\
\text { respiratory protective equipment. } \\
\qquad \begin{array}{c}\text { WARNING } \\
\text { Picture 4: Example of demarcated respirator zone } \\
\text { signage. }\end{array}\end{array}$ \\
\hline
\end{tabular}

Information regarding particle sizes and metal composition of fumes may assist the engineering department of the mine to design equipment and control measures to decrease or eliminate exposure to gouging and lancing fumes as well as to determine if the current equipment and control measures are efficient.

\subsubsection{Personal protective equipment (PPE)}

PPE is considered as the last resort in terms of exposure control according to the hierarchy of control. It may be used in combination with engineering and administrative controls. When these controls are not adequate, or while they are being implemented, respirators and other PPE could be used to help reduce exposure to nanoparticles and other particle size fractions. RPE should be used correctly as part of a comprehensive respiratory programme, which includes training, fit testing (to prevent face seal leakage) and medical evaluation (3M Technical Data Bulletin, 2015). PPE should be used to reduce worker exposure and if used correctly, may reduce the risk to develop illnesses caused by exposure to metal cutting fumes. Observations and recommendations regarding PPE usage continue on the next page. 


\begin{tabular}{|c|c|}
\hline Observation & Recommendation \\
\hline $\begin{array}{l}\text { Workers were equipped with the following } \\
\text { PPE: } \\
\text { - Welding face shield } \\
\text { - Custom-made hearing protection } \\
\text { - Coveralls with reflector stripes and turn- } \\
\text { ups } \\
\text { - Welding aprons } \\
\text { - Welding gloves and sleeves } \\
\text { - Safety boots } \\
\text { - Dräger Piccola FFP2 S-V Carbon dust } \\
\text { mask (protects against welding fumes } \\
\text { and is equipped with a special carbon } \\
\text { layer and an odour filter). } \\
\text { One worker was also equipped with a } \\
\text { harness, since he was working at a height of } \\
1.5 \text { m. }\end{array}$ & $\begin{array}{l}\text { PPE worn by the workers could be re- } \\
\text { evaluated to ensure sufficient protection and } \\
\text { may include the following, in addition to PPE } \\
\text { that is already being used: } \\
\text { - Safety boots made of low permeability } \\
\text { material. } \\
\text { - Trousers without turn-ups. } \\
\text { - Clothes made out of woven fibres. } \\
\text { - NIOSH-certified half-face or full-face air- } \\
\text { purifying respirators with P100 filtering } \\
\text { media (used for any type of aerosol) in a } \\
\text { cartridge to remove nanoparticles, } \\
\text { gasses and vapours. }\end{array}$ \\
\hline
\end{tabular}

Information regarding particulate size exposure may be used to re-evaluate the respiratory protective equipment used by the mine and to determine if the RPE is efficient for this exposure, especially for nanoparticle exposure. This will ensure that the respirators used during gouging and lancing processes are adequate to protect workers against specific particle sizes and metals.

\subsubsection{Education and training}

Employees working with or in close proximity to gouging and lancing processes should be educated on the particle size exposure of these processes as well as how these particles penetrate and are distributed into the respiratory tract. This may lead to an informed worker that understands why it is necessary to wear specific protective equipment and this may influence their behaviour regarding compliance with PPE guidelines. Programmes regarding the use of different PPE and RPE should be implemented to inform and train workers on how to correctly use or wear various PPE and RPE. 


\subsection{References}

3M Technical Data Bulletin. (2015) Nanotechnology and Respirator Use. Available from: URL: http://multimedia.3m.com/mws/media/3761790/nanotechnology-and-respirator-use.pdf (accessed 5 October 2016)

Antonini JM. (2003) Health Effects of Welding. Crit Rev Toxicol; 33: 61-103.

DiscoveryBlog. (2016) Local Exhaust Ventilation - When To Call In The Pros. Available from: URL: http://thediscoveryblog.com/local-exhaust-ventilation-systems-when-to-call-in-the-pros/ (accessed 14 October 2016)

Hariri A, Azreen N, Abdull N et al. (2014) Determination of customer requirement for welding fumes index development in automotive industries by using quality function deployment approach. Int J Automot Mech Eng; 9: 1609-1619.

Hartmann L, Bauer M, Bertram J et al. (2014) Assessment of the biological effects of welding fumes emitted from metal inert gas welding processes of aluminium and zinc-plated materials in humans. Int J Hyg Envir Health; 217: 160-168.

IARC (International Agency for Research on Cancer). (1989) Monographs on the evaluation of carcinogenic risks to humans (Volume 47): Some organic solvents, resin monomers and related compounds, pigments and occupational exposures in paint manufacture and painting. Available from: URL: http://monographs.iarc.fr/ENG/Monographs/vol47/mono47.pdf (accessed 16 June 2016)

IARC (International Agency for Research on Cancer). (1991) Monographs on the evaluation of carcinogenic risks to humans (Volume 52): Chlorinated drinking-water; chlorination by-products; some other halogenated compounds; cobalt and cobalt compounds. Available from: URL: http://monographs.iarc.fr/ENG/Monographs/vol52/mono52.pdf (accessed 10 May 2015)

IARC (International Agency for Research on Cancer). (1993) Monographs on the evaluation of carcinogenic risks to humans (Volume 58): Beryllium, cadmium, mercury and exposures in the glass manufacturing industry. Available from: URL: https://monographs.iarc.fr/ENG/Monographs/vol58/mono58.pdf (accessed 16 June 2016)

IARC (International Agency for Research on Cancer). (2006a) Monographs on the evaluation of carcinogenic risks to humans (Volume 86): Cobalt in Hard Metals and Cobalt Sulfate, Gallium Arsenide, Indium Phosphide and Vanadium Pentoxide. Available from: URL: http://monographs.iarc.fr/ENG/Monographs/vol86/mono86.pdf (accessed 10 May 2015) 
IARC (International Agency for Research on Cancer). (2006b) Monographs on the evaluation of carcinogenic risks to humans (Volume 87): Inorganic and Organic Lead Compounds. Available from: URL: http://monographs.iarc.fr/ENG/Monographs/vol87/mono87.pdf (accessed 10 May 2015)

IARC (International Agency for Research on Cancer). (2012a) Monographs on the evaluation of carcinogenic risks to humans (Volume 100C): Arsenic, metals, fibres, and dusts. Available from: URL: http://monographs.iarc.fr/ENG/Monographs/vol100C/mono100C.pdf (accessed 10 May 2015)

IARC (International Agency for Research on Cancer). (2012b) Monographs on the evaluation of carcinogenic risks to humans (Volume 100F): Chemical agents and related occupations. Available from: URL: http://monographs.iarc.fr/ENG/Monographs/vol100F/mono100F.pdf (accessed 10 May 2015)

Kang GS, Gillespie PA, Gunnison A et al. (2011) Long-term inhalation exposure to nickel nanoparticles exacerbated atherosclerosis in a susceptible mouse model. Environ Health Persp; 119: 176-181.

La Vecchia GM, Maestrelli P. (2011) New welding processes and health effects of welding (Italian). G Ital Med Lav Ergon; 33: 252-256.

Lehnert M, Pesch B, Lotz A et al. (2012) Exposure to inhalable, respirable, and ultrafine particles in welding fume. Ann Occup Hyg; 56; 557-567.

Nilsson PT, Isaxon C, Eriksson AC et al. (2013) Nano-objects emitted during maintenance of common particle generators: direct chemical characterization with aerosol mass spectrometry and implications for risk assessments. J Nanopart Res; 15: 1-16.

Oberdörster G, Kane AB, Klaper RD, Hurt RH. (2013) Nanotoxicology. In Klaassen CD, editor. Casarett \& Doull's Toxicology: The Basic Science of Poison. China: McGraw-Hill. p. 1189-1229. ISBN 978-0-07-176923-5.

Occupational Safety and Health Administration (OSHA). (2013) Fact Sheet: Working Safely with Nanomaterials. Available from: URL: https://www.osha.gov/Publications/OSHA_FS-3634.pdf (accessed 14 October 2016)

Peixe TS, de Souza Nascimento E, Schofield KL et al. (2015) Nanotoxicology and exposure in the occupational setting. Occup Dis Environ Med; 3: 35-48. 
Persoons R, Arnoux D, Monssu T et al. (2014) Determinants of occupational exposure to metals by gas metal arc welding and risk management measures: A bio monitoring study. Toxicol Lett; 231: 135-141.

Pickford G, Davies B. (2007) Aerosols. In Tillman C, editor. Principles of Occupational Health \& Hygiene: An Introduction. Singapore: ANL Printers. p. 125-171. ISBN 9781741750584.

Schulte P, Geraci C, Zumwalde R et al. (2008) Occupational Risk Management of Engineered Nanoparticles. J Occup Environ Hyg; 5: 239-249.

Sriram K, Lin GX, Jefferson AM et al. (2015) Modifying welding process parameters can reduce the neurotoxic potential of manganese-containing welding fumes. Toxicology; 328: 168-178.

Tashiro S, Zeniya T, Yamamoto K et al. (2015) Numerical analysis of fume formation mechanism in TIG welding. Weld Int; 29: 165-172.

Vincent JH, Brosseau LM. (1995) The nature and properties of workplace airborne contaminants. In Harrington JM, Gardiner K, editors. Occupational Hygiene. Oxford: Blackwell Science Ltd. p. 61-83. ISBN 0-632-03734-2.

Wardhana, Datau EA. (2014) Metal fume fever among galvanised welders. Indones J Intern Med; 46: 256-262.

Wilson WE, Chow JC, Claiborn C et al. (2002) Monitoring of particulate matter outdoors. Chemosphere; 49: 1009-1043.

Wittczak T, Walusiak J, Palczyński C. (2009) Welding-related respiratory diseases. Med Pr; 60: 201-208.

Zeidler-Erdely PC, Erdely A, Antonini JM. (2012) Immunotoxicology of arc welding fume: Employee and experimental animal studies. J Immunotoxicol; 9: 411-425. 


\section{CHAPTER 6: ANNEXURES}

\subsection{Annexure A: Table 1 and Table 2}

Tables 1 and 2 show the descriptive statistical data for various metals present in the inhalable and thoracic particle size fractions emitted during gouging and lancing processes in the maintenance workshop, the mining contractor's workshop and the secondary crusher workshop. The grey blocks indicate that a metal was not present in the specific fraction or that less than $50 \%$ of the values were available and therefore, $\beta$-substitution was not carried out and the information was not included in the tables. 
Table 1: Descriptive statistical data for various metals present in the inhalable particle size fraction.

\begin{tabular}{|c|c|c|c|c|c|c|c|c|c|c|c|c|c|c|c|}
\hline \multirow{3}{*}{ Metal } & \multicolumn{15}{|c|}{ Inhalable fraction } \\
\hline & \multicolumn{5}{|c|}{$\begin{array}{c}\text { Gouging }(n=5) \\
\text { Maintenance workshop }\end{array}$} & \multicolumn{5}{|c|}{$\begin{array}{c}\text { Gouging }(n=5) \\
\text { Contractor's workshop }\end{array}$} & \multicolumn{5}{|c|}{$\begin{array}{c}\text { Lancing }(n=6) \\
\text { Secondary crusher workshop }\end{array}$} \\
\hline & Mean & Min & Max & Median & SD & Mean & Min & Max & Median & SD & Mean & Min & Max & Median & SD \\
\hline Aluminium (Al) & 0.0054 & 0.0002 & 0.0187 & 0.0014 & 0.0078 & & & & & & 0.0022 & 0.0003 & 0.0047 & 0.0016 & 0.0020 \\
\hline \multicolumn{16}{|l|}{ Antimony (Sb) } \\
\hline Arsenic (As) & & & & & & & & & & & 0.0009 & 0.0005 & 0.0012 & 0.0010 & 0.0003 \\
\hline Barium $(\mathrm{Ba})$ & & & & & & & & & & & 0.0015 & 0.0005 & 0.0022 & 0.0018 & 0.0007 \\
\hline Calcium (Ca) & 0.0296 & 0.0101 & 0.0547 & 0.0259 & 0.0165 & 0.0269 & 0.0064 & 0.0418 & 0.0262 & 0.0134 & 0.0203 & 0.0092 & 0.0508 & 0.0151 & 0.0153 \\
\hline Chromium (Cr) & 0.0057 & 0.0022 & 0.0172 & 0.0030 & 0.0065 & 0.0064 & 0.0022 & 0.0104 & 0.0065 & 0.0029 & 0.0044 & 0.0032 & 0.0060 & 0.0042 & 0.0012 \\
\hline \multicolumn{16}{|l|}{ Cobalt (Co) } \\
\hline Copper $(\mathrm{Cu})$ & 0.0231 & 0.0071 & 0.0720 & 0.0097 & 0.0277 & 0.0390 & 0.0100 & 0.0690 & 0.0347 & 0.0215 & 0.0053 & 0.0011 & 0.0121 & 0.0034 & 0.0050 \\
\hline Iron $(\mathrm{Fe})$ & 1.2739 & 0.3974 & 3.4246 & 0.8941 & 1.2379 & 1.6137 & 0.3602 & 3.5023 & 1.2628 & 1.1818 & 1.0877 & 0.5299 & 2.1526 & 0.8639 & 0.6139 \\
\hline Lead $(\mathrm{Pb})$ & & & & & & & & & & & 0.0012 & 0.0005 & 0.0022 & 0.0010 & 0.0007 \\
\hline Magnesium (Mg) & 0.0038 & 0.0012 & 0.0080 & 0.0038 & 0.0027 & & & & & & 0.0023 & 0.0004 & 0.0060 & 0.0019 & 0.0021 \\
\hline Manganese (Mn) & 0.0521 & 0.0175 & 0.1595 & 0.0198 & 0.0612 & 0.0549 & 0.0108 & 0.0943 & 0.0629 & 0.0349 & 0.1099 & 0.0212 & 0.2777 & 0.0719 & 0.1022 \\
\hline \multicolumn{16}{|l|}{ Mercury $(\mathrm{Hg})$} \\
\hline Molybdenum (Mo) & 0.0042 & 0.0004 & 0.0136 & 0.0017 & 0.0055 & 0.0041 & 0.0012 & 0.0102 & 0.0018 & 0.0038 & 0.0090 & 0.0022 & 0.0202 & 0.0061 & 0.0074 \\
\hline Nickel (Ni) & 0.0058 & 0.0005 & 0.0146 & 0.0016 & 0.0065 & 0.0099 & 0.0028 & 0.0325 & 0.0035 & 0.0128 & 0.0017 & 0.0004 & 0.0034 & 0.0014 & 0.0011 \\
\hline \multicolumn{16}{|l|}{ Palladium $(\mathrm{Pd})$} \\
\hline Potassium $(\mathrm{K})$ & 0.0042 & 0.0008 & 0.0083 & 0.0043 & 0.0027 & 0.0024 & 0.0003 & 0.0056 & 0.0013 & 0.0025 & 0.0058 & 0.0003 & 0.0088 & 0.0066 & 0.0030 \\
\hline \multicolumn{16}{|l|}{ Selenium (Se) } \\
\hline \multicolumn{16}{|l|}{ Silver $(\mathrm{Ag})$} \\
\hline \multicolumn{16}{|l|}{ Sodium $(\mathrm{Na})$} \\
\hline \multicolumn{16}{|l|}{ Strontium (Sr) } \\
\hline $\operatorname{Tin}(\mathrm{Sn})$ & 0.0312 & 0.0162 & 0.0591 & 0.0296 & 0.0168 & 0.0330 & 0.0099 & 0.0672 & 0.0194 & 0.0242 & 0.0241 & 0.0087 & 0.0312 & 0.0262 & 0.0079 \\
\hline Titanium (Ti) & 0.0033 & 0.0014 & 0.0066 & 0.0027 & 0.0021 & & & & & & & & & & \\
\hline \multicolumn{16}{|l|}{ Tungsten (W) } \\
\hline Zinc $(Z n)$ & & & & & & 0.0011 & 0.0006 & 0.0018 & 0.0011 & 0.0004 & 0.0012 & 0.0002 & 0.0032 & 0.0007 & 0.0012 \\
\hline Zirconium (Zr) & & & & & & & & & & & & & & & \\
\hline
\end{tabular}


Table 2: Descriptive statistical data for various metals present in the thoracic particle size fraction.

\begin{tabular}{|c|c|c|c|c|c|c|c|c|c|c|c|c|c|c|c|}
\hline \multirow{3}{*}{ Metal } & \multicolumn{15}{|c|}{ Thoracic fraction } \\
\hline & \multicolumn{5}{|c|}{$\begin{array}{c}\text { Gouging }(n=5) \\
\text { Maintenance workshop }\end{array}$} & \multicolumn{5}{|c|}{$\begin{array}{c}\text { Gouging }(n=5) \\
\text { Contractor's workshop }\end{array}$} & \multicolumn{5}{|c|}{$\begin{array}{c}\text { Lancing }(n=6) \\
\text { Secondary crusher workshop }\end{array}$} \\
\hline & Mean & Min & Max & Median & SD & Mean & Min & Max & Median & SD & Mean & Min & Max & Median & SD \\
\hline Aluminium (Al) & 0.0168 & 0.0024 & 0.0350 & 0.0085 & 0.0154 & 0.0083 & 0.0002 & 0.0256 & 0.0060 & 0.0104 & 0.0052 & 0.0003 & 0.0126 & 0.0048 & 0.0048 \\
\hline \multicolumn{16}{|l|}{ Antimony (Sb) } \\
\hline Arsenic (As) & & & & & & & & & & & 0.0025 & 0.0012 & 0.0039 & 0.0023 & 0.0011 \\
\hline \multicolumn{16}{|l|}{ Barium $(\mathrm{Ba})$} \\
\hline Calcium (Ca) & 0.0945 & 0.0192 & 0.1989 & 0.0555 & 0.0789 & 0.0638 & 0.0191 & 0.1774 & 0.0470 & 0.0648 & 0.1768 & 0.0275 & 0.8401 & 0.0466 & 0.3255 \\
\hline Chromium (Cr) & 0.0150 & 0.0089 & 0.0310 & 0.0101 & 0.0093 & 0.0127 & 0.0087 & 0.0230 & 0.0102 & 0.0059 & 0.0105 & 0.0073 & 0.0138 & 0.0104 & 0.0032 \\
\hline \multicolumn{16}{|l|}{ Cobalt (Co) } \\
\hline Copper (Cu) & 0.0369 & 0.0131 & 0.1137 & 0.0197 & 0.0432 & 0.0493 & 0.0251 & 0.1261 & 0.0269 & 0.0435 & 0.0091 & 0.0020 & 0.0165 & 0.0087 & 0.0074 \\
\hline Iron $(\mathrm{Fe})$ & 1.7179 & 0.8932 & 4.7513 & 1.0178 & 1.6968 & 1.8740 & 0.7904 & 5.5385 & 0.9940 & 2.0519 & 1.4182 & 1.0148 & 1.7275 & 1.4376 & 0.2359 \\
\hline Lead $(\mathrm{Pb})$ & & & & & & & & & & & 0.0018 & 0.0007 & 0.0036 & 0.0016 & 0.0012 \\
\hline Magnesium (Mg) & 0.0110 & 0.0011 & 0.0202 & 0.0120 & 0.0072 & 0.0063 & 0.0027 & 0.0156 & 0.0035 & 0.0054 & 0.0341 & 0.0025 & 0.1763 & 0.0062 & 0.0697 \\
\hline Manganese $(\mathrm{Mn})$ & 0.0808 & 0.0179 & 0.2475 & 0.0407 & 0.0944 & 0.0693 & 0.0246 & 0.1725 & 0.0485 & 0.0603 & 0.1081 & 0.0384 & 0.2038 & 0.1006 & 0.0746 \\
\hline \multicolumn{16}{|l|}{ Mercury $(\mathrm{Hg})$} \\
\hline Molybdenum (Mo) & 0.0061 & 0.0005 & 0.0203 & 0.0044 & 0.0082 & 0.0049 & 0.0012 & 0.0157 & 0.0028 & 0.0061 & 0.0136 & 0.0046 & 0.0258 & 0.0128 & 0.0092 \\
\hline Nickel (Ni) & 0.0082 & 0.0019 & 0.0179 & 0.0034 & 0.0080 & 0.0141 & 0.0010 & 0.0590 & 0.0033 & 0.0252 & 0.0029 & 0.0006 & 0.0063 & 0.0026 & 0.0019 \\
\hline \multicolumn{16}{|l|}{ Palladium $(\mathrm{Pd})$} \\
\hline Potassium (K) & 0.0279 & 0.0066 & 0.0501 & 0.0212 & 0.0201 & 0.0134 & 0.0077 & 0.0278 & 0.0097 & 0.0083 & 0.0263 & 0.0086 & 0.0655 & 0.0215 & 0.0204 \\
\hline \multicolumn{16}{|l|}{ Selenium (Se) } \\
\hline \multicolumn{16}{|l|}{ Silver $(\mathrm{Ag})$} \\
\hline Sodium (Na) & 0.2180 & 0.0062 & 0.5703 & 0.1746 & 0.2109 & 0.2841 & 0.1559 & 0.4165 & 0.2648 & 0.1154 & 0.1963 & 0.0002 & 0.2952 & 0.2458 & 0.1210 \\
\hline \multicolumn{16}{|l|}{ Strontium (Sr) } \\
\hline $\operatorname{Tin}(\mathrm{Sn})$ & 0.0572 & 0.0435 & 0.0719 & 0.0614 & 0.0129 & 0.0663 & 0.0424 & 0.1099 & 0.0615 & 0.0268 & 0.0501 & 0.0350 & 0.0613 & 0.0546 & 0.0110 \\
\hline Titanium $(\mathrm{Ti})$ & 0.0038 & 0.0014 & 0.0074 & 0.0030 & 0.0023 & & & & & & & & & & \\
\hline \multicolumn{16}{|l|}{ Tungsten (W) } \\
\hline Zinc (Zn) & 0.0185 & 0.0030 & 0.0393 & 0.0170 & 0.0132 & 0.0057 & 0.0028 & 0.0119 & 0.0049 & 0.0035 & 0.0071 & 0.0004 & 0.0219 & 0.0053 & 0.0076 \\
\hline Zirconium (Zr) & 0.0011 & 0.0007 & 0.0016 & 0.0010 & 0.0004 & 0.0011 & 0.0006 & 0.0017 & 0.0011 & 0.0005 & & & & & \\
\hline
\end{tabular}


6.2 Annexure B: Language Editing Certificate

\section{To whom it may concern}

It is hereby certified that I have language edited the Mini-Dissertation

"Particle size and metal composition of gouging and lancing fumes"

by

M Keyter

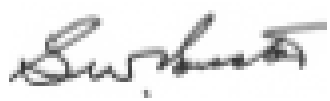

11 November 2016

Prot sW Vorcter

Aooredited Member No. 1000923

south Afriloan Tranclatore" Inctitute

Cell 0727197025

schalk. vorsterenenw.sc.zs 
6.3 Annexure C: Winner of Student Poster Presentation at SAIOH Conference 2016 Certificate of Recognition

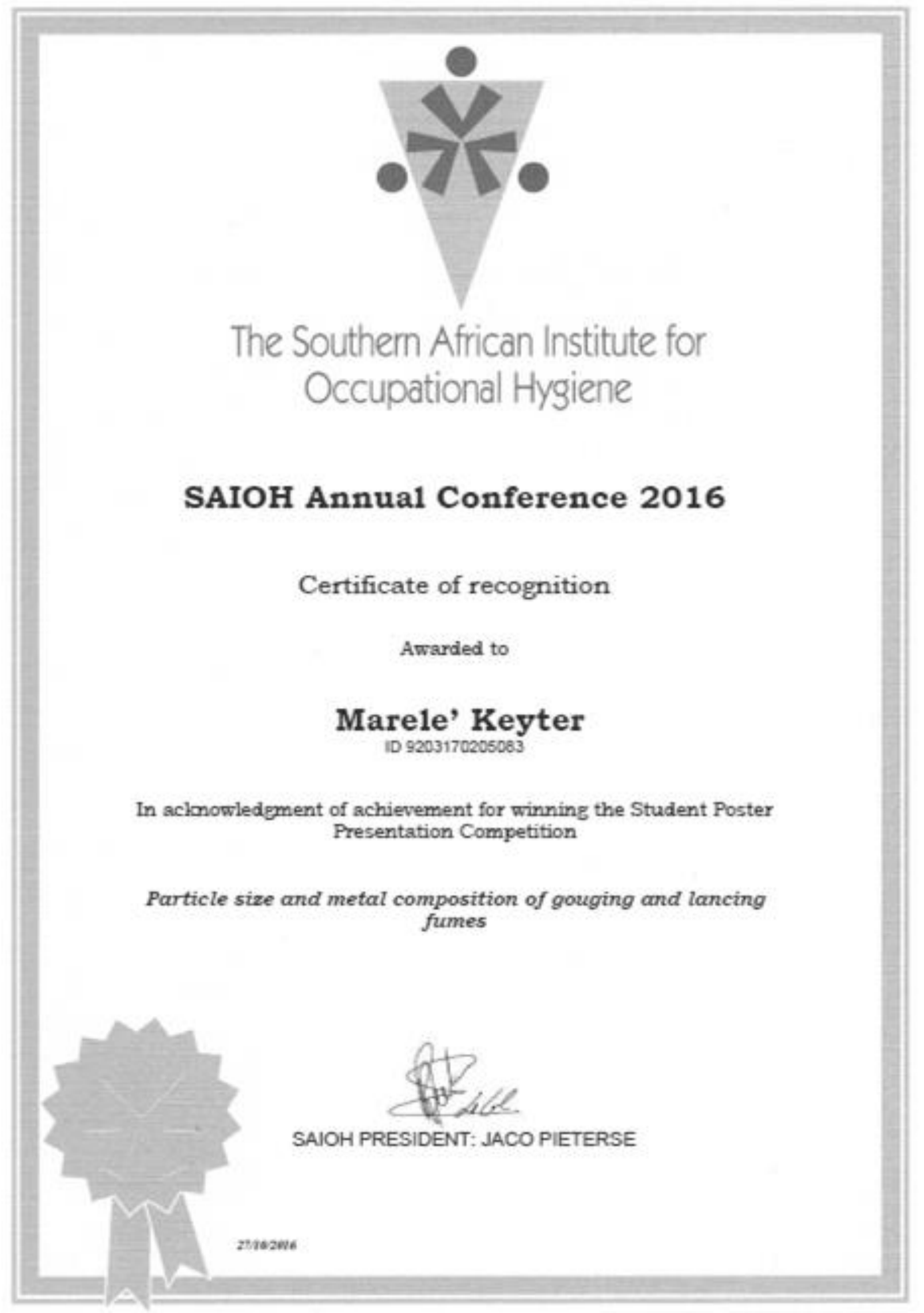




\subsection{Annexure D: Poster exhibited at SAIOH Conference 2016}

\section{PARTICLE SIZE AND METAL COMPOSITION OF GOUGING AND LANCING FUMES}

M Keyter ${ }^{2}$, A Van der Merwe ${ }^{1}$, A Franken ${ }^{1}$, CJ Badenhorst ${ }^{1,2}$, Z Selenati-Dreyer ${ }^{2}$

${ }^{1}$ Occupational Hygiene and Health Research Initiative (OHHRI), Faculty of Health Sciences, North-West University, Potchefstroom Campus, South Africa \& ${ }^{2}$ Anglo American Ltd

\section{BACKGROUND}

The processes of gouging (used for preparstion of the weld groove) and lancing (severs or removes metal) fiberate metal fumes, to which mining maintenance workers are exposed 12 . The particle sibes and composition of these metal fumes are unknown. Metal fumes are comprised of a complex mixture of various toxic metsis that mav cause sdverse health effects through the inhalation thereof 24 .

\section{AIM}

The study aimed to determine the potential presence and size of particles in various respiratory fractions, as well as metal composition of fumes emitted during gouging and lancing processes.

\section{METHOD}

Rondomized side-by-side ares samples of metal cutting fumes were collected in three workshops at a mine in South Africa using $10 \mathrm{M}$ samplers (inhalable fraction), GK2.69 cyclones (thoracic fraction), aluminium cyclones (respirable fraction], NRD samplers (nano-sized fraction) snd open-face fitter cassettes (particle size distribution).

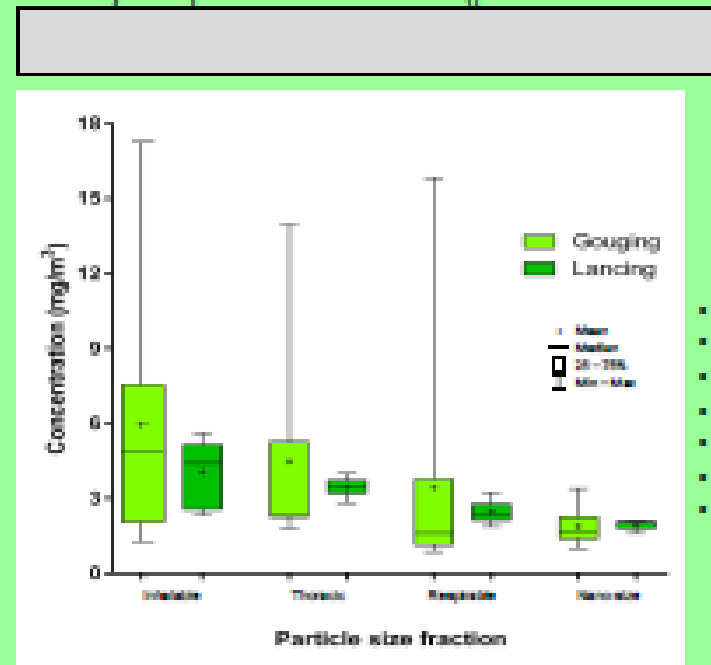

Ficure 1: Descripthe statistical data for inhalable, thonacic, reapinble and nano-sire particle size fractions.

\section{DISCUSSION}

- Inhalable, thoracic, respirable and nano-size fractions were present in gouging and lancing fumes.

- Lancing could be considered more hazardous than gougingsmaller mean particle sizes.

- Smaller particles-deposit in deepest structures of respiratory tract, absorbed into blood circulation and transported to other regions of body.

- Legislation concentrates on inhalable and respirable fractions; however, this study indicated the presence of nanoparticles.

- Nanotoxicology-unfamiliar field.

- Adverse health effects outside of the respiratory system and metals in this fraction may react differently in the respiratory system and body.

- Occupational hygiene should go beyond compliance and protect workers through minimising exposure to nanoparticles.

\section{RESULTS}

Total of 26 metals

Including the following prominent metals:

Aluminium - Manganese

Arsenic - Nickel

Onromium - Siver

Cobait - Tín

Lesd

Nominkin, choming, lase.

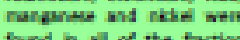
lisen in bath proculese.

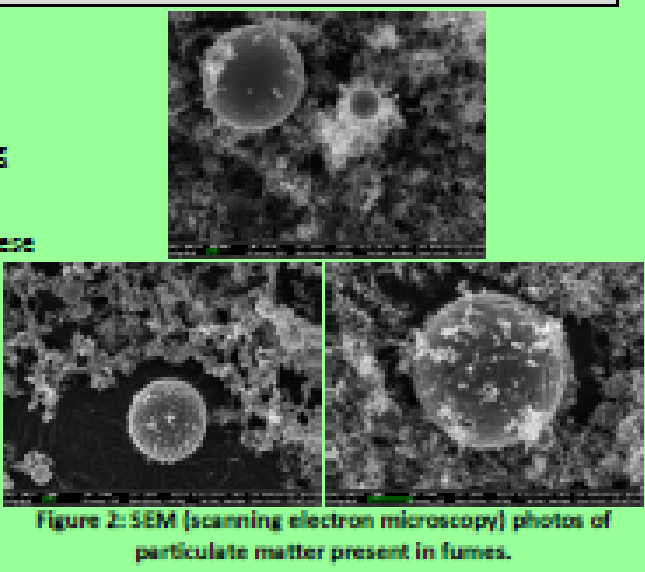

CONCLUSION

All four fractions and a total of 26 metals were present in the fumes liberated during gouging and lancing.

- This inclicates the necessity to include the nano-size fraction during future personal and area exposure assessments and monitoring in addition to inhalable and respirable sampling.

- The results indicate the importance of implementing various control methods to reduce worker exposure, specifically to nanoparticles.

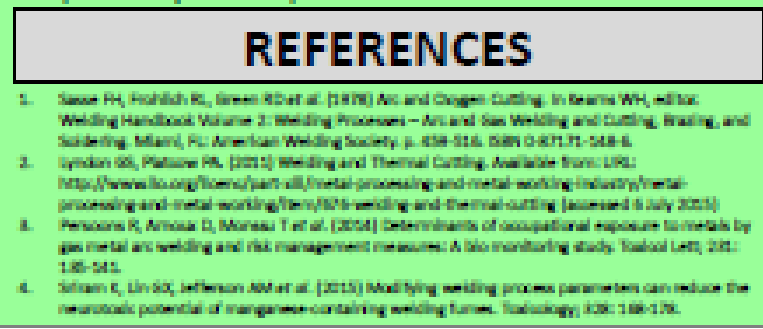

